INSTITUTO DE PESQUISAS ENERGÉTICAS E NUCLEARES Autarquia Associada à Universidade de São Paulo

\title{
RECONSTRUÇÃO TRIDIMENSIONAL DE SUPERFÍCIES DE FRATURA DE MATERIAIS COMPÓSITOS DO TIPO CFRP
}

\author{
RAQUEL DE MORAES LOBO
}

Tese apresentada como parte dos requisitos para obtenção do Grau de Doutor em Ciências na Área de Tecnologia Nuclear de Materiais.

Orientador:

Dr. Arnaldo H. Paes de Andrade

SÃO PAULO

2009 


\section{Aos meus amigos!}

Verdadeiros e fiéis amigos...

Que me ajudaram a mudar o rumo da história, E a lutar destemidamente para que mais uma vez, A força do direito tenha vencido o direito da força... Que Deus nos conserve assim, nada conservadores! 


\section{Agradecimentos}

Durante a execução do trabalho muitos fatos ocorreram, que propiciaram um grande aprendizado, dos científicos aos humanitários e filosóficos. O tempo não para, o novo sempre vem e como diz D. Glória Fontanelli (minha mãe), não há bem que não se acabe e nem há mal que sempre dure. Este período foi enriquecedor, em ambas as partes e agora que chega ao fim gostaria de agradecer as pessoas que permitiram a fluidez dos fatos.

Agradeço ao meu orientador, Prof. Dr. Arnaldo Homobono Paes de Andrade, pela orientação, paciência e visibilidade com que direcionou 0 trabalho, participando de todas as etapas, estando sempre presente nas horas difíceis e enfrentando os obstáculos, com senso de justiça e boa dose de serenidade, atitudes inerentes aqueles que são íntegros e incorruptíveis. $E$, por falar em integridade, seu curso de mecânica da fratura foi fundamental para o começo de tudo.

Ao Prof. Dr. Luis Rogerio de Oliveira Hein, com quem aprendi muito sobre análise de imagens durante seu curso, em Guaratinguetá. Embora a distância fosse grande, foi compensador e prazeroso realizar essa jornada, pois tudo que é bom vale a pena. Agradeço pelo acesso aos programas e laboratórios da UNESP sem os quais, nada seria possivel. $O$ maior ensinamento foi que a melhor imagem nem sempre é aquela que agrada aos olhos, mas a que contém mais conteúdo. Obrigado pela oportunidade que me deu de viver o único momento cor-de-rosa do trabalho.

O curso de materiais compósitos, que além da abrangência teórica também permitiu a manipulação de resinas e fibras foi fundamental para 0 melhor entendimento sobre a flexibilidade $e$ as diversas facetas deste material. Por possibilitar a oportunidade de colocar a mão na massa, agradeço ao Prof. Dr. Gerson Marinucci, que além do curso forneceu as amostras, que foram imprescindíveis para a realização desta tese.

A microscopia foi uma das partes fundamentais deste trabalho. Agradeço imensamente a "terá" ajuda de Aparecido Morcelli, que permitiu acesso irrestrito ao seu laboratório de microscopia eletrônica, alterando diversos parâmetros durante a aquisição das imagens, no momento que outras portas se fecharam. 
Um agradecimento especial a colaboração e sugestões dadas por aqueles que participaram das fases de avaliação do trabalho: Dr. Waldemar Monteiro, Dr. Sidnei Buso, Dr. Mario Olímpio de Menezes e Dr. César Azevedo.

Havia uma pedra no caminho, no meio do caminho havia uma pedra. Se fosse apenas poesia, seria simplesmente belo. Sendo realidade, poderia inviabilizar toda e qualquer caminhada. A pedra era dura e parecia intransponível devido ao emaranhado de coisas que a sustentavam. É certo que os sustentáculos não eram legítimos e nem de boa qualidade, mas pela podridão que representavam, requeriam muito cuidado e habilidade durante a remoção. Fazer sozinha o trabalho era inviável e a força necessária seria colossal. Tive ajuda de pessoas especialíssimas e idôneas. Verdadeiros diamantes, jóias raras e preciosas, das quais é possivel se orgulhar em possuí-las bem próximas, inexoravelmente tangíveis, e que justificam certo prazer em se fazer parte da raça humana. Meus verdadeiros amigos, eu agradeço imensamente os gestos, as palavras e atitudes que tomaram até a minha defesa.

Reconstruir parece que foi mesmo o objetivo do trabalho, e no sentido mais amplo da palavra, a reconstrução determinando ponto a ponto as altitudes de cada pixel formador da imagem. A imagem final revelando vales profundos e altitudes elevadas. Tudo parece filosófico, a arte imitando a vida. Nada é mais edificante do que o viver.

Agradeço a ajuda dos meus velhos e bons amigos Arnaldo (Andrade) $e$ Carlos Alberto (da Silva Queiroz), que com bondade e nobreza me incentivaram e deram apoio irrestrito, e mesmo sendo dois, foram ímpares nas atitudes.

Agradeço também as minhas amigas Stela Maria (Fernandes), Betinha (Elisabete dos Santos) e a Jenedite (de Souza Nascimento) pelo carinho e compreensão nas horas certas.

Um agradecimento especial para Bibiana, Bianca e Belisa que me acompanharam em tudo, apontando com esperanças para um futuro melhor, um novo tempo, de dias melhores. 


\title{
RECONSTRUÇÃO TRIDIMENSIONAL DE SUPERFÍCIES DE FRATURA DE MATERIAIS COMPÓSITOS DO TIPO CFRP
}

\author{
Raquel de Moraes Lobo
}

\section{RESUMO}

A reconstrução tridimensional de superfícies de fratura de materiais compósitos do tipo CFRP é apresentada neste trabalho como um método possível para análise fractográfica desse material, cuja superfície de fratura pode apresentar uma rugosidade acentuada, com grande variação em altura. Dois métodos são apresentados para esse propósito: a reconstrução por foco variável, realizada com imagens de microscopia óptica e a reconstrução por paralaxe, realizada com par de imagens estéreo, obtidas por microscopia eletrônica de varredura. Uma avaliação é realizada para cada um dos dois métodos, discutindo seus limites e a eficiência de cada um deles, perante as dificuldades de análise de materiais compósitos unidirecionais e multidirecionais. O método de foco variável apresentou um excelente resultado de reconstrução, mas tem a necessidade de um número grande de imagens, tempo de dedicação do instrumento e limite de ampliação das imagens como fatores a serem considerados na escolha de melhor método. As inclinações da amostra, durante o método da paralaxe, revelam alterações nos histogramas das imagens adquiridas no sentido horário que limitam o uso do método para materiais com alta rugosidade. A obtenção de imagens em um único sentido e a construção de uma região de interesse, posicionada no centro da imagem são sugestões para tornar o método mais abrangente. A linearidade das projeções de características na imagem inclinada também sugere a possibilidade de realizar a reconstrução utilizando, em vez de apenas duas, múltiplas imagens obtidas no sentido anti-horário. As alterações propostas para modificar a rotina, são sugeridas para que o programa possa ser aplicado de forma mais abrangente, independente da qualidade da superfície de fratura observada. 


\title{
THREE-DIMENSIONAL RECONSTRUCTION OF FRACTURE SURFACES OF CFRP TYPE COMPOSITE MATERIALS
}

\author{
Raquel de Moraes Lobo
}

\begin{abstract}
The three-dimensional reconstruction of fracture surfaces of CFRP type composite materials is presented in this work as a possible method for the fractographic analysis of this material, whose rupture surface can present an accentuated roughness, with great variation in height. Two methods are presented for this purpose: the reconstruction for variable focus, carried through with images of optic microscopy and the reconstruction for parallax, carried through with pair of stereo images, obtained by means of scanning electronic microscopy. An evaluation is carried through for each one of the two methods, having argued its limits and the efficiency of each one of them, before the difficulties of analysis of unidirectional and multidirectional composite materials. The method of variable focus presented an excellent reconstruction result, but it has the need of a great number of images, spent time of the instrument and magnifying limit of the images as factors to be considered in the choice of better method. The tilting of the specimen, during the parallax method, discloses alterations in the histograms of the images acquired in the clockwise direction that limit the use of the method for materials with high roughness. The acquiring of images in only one direction and the construction of a region of interest, located in the center of the image are suggestions to turn the method most including. The linearity of the projections of features in the inclined image also suggests the possibility to carry through the reconstruction using, instead of only two, multiple images gotten in the counter-clockwise direction. The alterations proposals to modify the routine, are suggested so that the program can be applied in a more comprehensive form, independent of the quality of the observed fracture surface.
\end{abstract}




\section{Lista de Figuras}

Figura

01 Esquema para o processo de fratura do compósito reforçado com fibra de carbono de: (a) 3,5 GPa e (b) 5,5 GPa (Y. Tomita and M. Tempaku).

02 Esquema de formação de falha por cisalhamento na matriz polimérica e formação de "cuspides", com o aumento da tensão cisalhante (D. Purslow).

03 Fratura compressiva, em região rica em resina, com indicação da direção 16 de propagação (Shikhmanter, I. and Eldror, B. Cina).

04 Esquema sobre o aumento do número de elétrons detectados, conforme o aumento na inclinação de amostras em MEV (Brooks, C. R. e McGill, B. L.).

05 Amostras de material compósito unidirecional e multidirecional, utilizadas para a reconstrução $3 D$.

06 Página inicial do programa "ImageJ", com exemplos de resultados obtidos com suas ferramentas.

07 Esquema do processo de reconstrução a partir de uma pilha de imagens. 29

08 Esquema do processo de reconstrução 3D, através de par estéreo. 31

09 Imagens de superfície de fratura de material compósito obtidas com 34 diferentes tensões, com MEV XL-30, Philips.

10 Imagens de superfícies de fratura de material compósito, obtidas em MEV XL-30, Philips, com 5kV.

11 Superfícies de fratura de materiais compósitos contendo delaminação e 37 arrancamento de fibras.

12 Superfícies de fratura de materiais compósitos, obtidas com detector de elétrons retroespalhados.

13 Superfícies de fratura de materiais compósitos, obtidas com MEV Camscan S4 e tensão de aceleração de 20 kV.

14 Superfícies de fratura de materiais compósitos, obtidas em MEV Hitachi, TM 1000

15 (a) Imagem reconstruída de superfície de fratura de compósito unidirecional e (b) mapa de elevações, obtidos pelo método de variação de foco.

16 Imagens reconstruídas de superfície de fratura de compósito unidirecional obtidas pelo método de variação de foco.

17 Imagens reconstruídas de superfície de fratura de compósito unidirecional obtidas pelo método de variação de foco.

18 Reconstrução de superfície de fratura de compósito obtida pelo método da paralaxe: (a) par estéreo; (b) mapa de elevações. 

durante inclinações nos sentidos, horário e anti-horário. inclinadas em até $\pm 3^{\circ}$, nos sentidos anti-horário e horário.

21 Histogramas das imagens de superfícies de fratura de Al, inclinadas em até $\pm 3^{\circ}$, nos sentidos anti-horário e horário.

22 Exemplos das imagens de superfícies de fratura de $\mathrm{Cu}$, inclinadas nos sentidos horário e anti-horário.

23 Histogramas das imagens de superfície de fratura de amostras de cobre, inclinadas em até $\pm 6^{\circ}$, nos sentidos anti-horário e horário.

24 Imagens de superfície de fratura de material compósito CFRP nos sentidos horário (coluna à esquerda) e anti-horário (coluna à direita).

25 Histogramas das imagens de superfície de fratura de materiais compósito, inclinadas em até $\pm 7^{\circ}$.

26 Reconstrução de superfície de fratura de material compósito: (a) imagens originais com inclinação de $1^{\circ}$ e $6^{\circ}$; (b) mapa de elevações em 2D e 3D.

27 Par de imagens Mev, adquiridas a $1^{\circ}$ e $8^{\circ}$ respectivamente, utilizadas para reconstrução de compósito multidirecional.

28 Imagens de CFRP, inclinadas de $1^{\circ}$ a $8^{\circ}$, no sentido anti-horário.

29 Partes centrais das imagens da figura 28, de CFRP inclinadas de $1^{\circ}$ a $8^{\circ}$.

30 Esquema mostrando inclinações em sentido anti-horário e a projeção de uma característica de altura $\Delta \mathrm{Z}$.

31 Gráfico da variação da tangente de $\theta$ em função do ângulo de inclinação, mostrando a linearidade para o cálculo de projeções na imagem.

A1 Esquema representativo de materiais compósitos unidirecionais e 73 multidirecionais.

A2 Esquema de danos possíveis de acontecer em lâminas e laminados de materiais compósitos.

A3 Seqüência de passos que podem levar a formação de bandas vincadas ("kink band").

A4 Superfície de fratura de materiais compósitos do tipo CFRP. 77

B1 Esquema simplificado dos principais componentes de um MEV. 78

B2 Esquema de interação do feixe incidente com a amostra mostrando sinais 79 produzidos e a região de onde podem ser detectados.

B3 Esquemas mostrando a diferença entre o posicionamento não eucêntrico em (a) e (b) e o posicionamento eucêntrico em (c) e (d) (Philips). 
1 - Introdução

2 - Objetivo

3 - Revisão da Literatura $\quad 06$

$\begin{array}{ll}3.1 \text { - Materiais Compósitos } & 06\end{array}$

3.2 - Mecanismos de Fratura de Compósitos do tipo CFRP 10

$\begin{array}{ll}3.3 \text { - Fractografia } & 13\end{array}$

3.4 - Análise de Imagens $\quad 18$

4 - Materiais \& Métodos $\quad 25$

4.1 - Reconstrução por Foco Variável 29

4.2 - Reconstrução por Paralaxe 30

5 - Resultados \& Discussão 33

6 - Conclusões $\quad 69$

Apêndice A - Materiais Compósitos $\quad 71$

Apêndice B - Formação de Imagens em MEV 78

$\begin{array}{ll}\text { Referências } & 84\end{array}$ 


\section{Introdução}

No início, a idéia deste trabalho era estudar a mecânica da fratura de materiais compósitos, através de fractografia quantitativa. Essas fractografias seriam analisadas por programas comerciais de análise de imagens, com o intuito de identificar e dimensionar as características da superfície de fratura. $\mathrm{O}$ modo de fratura que se desejava estudar era o arrancamento das fibras de carbono contínuas, que reforçam a matriz epóxi do compósito escolhido como material devido sua aplicação nuclear.

A medida que a compreensão sobre o problema aumentava, se tornava clara a necessidade de aprofundar o conhecimento em diversas áreas de ciência dos materiais. O passo inicial foi conhecer melhor o próprio material compósito, um material relativamente recente, com propriedades distintas, concebido com uma filosofia muito diferente daquilo que se costuma pensar sobre os outros materiais.

O processamento do material compósito começa com a determinação das propriedades que se deseja. Com a definição das propriedades, ele é projetado e manufaturado como produto final, pronto para ser usado, na forma definida no projeto. A flexibilidade desses projetos se tornou possível pelo fato da utilização das fibras de carbono em forma de fio ou tecido e, permitiu que fosse usado como material estrutural em projetos de alta tecnologia, aliando o alto módulo e resistência com uma baixa densidade.

O aumento na demanda desse material, para projetos em diversas áreas, onde confiabilidade e desempenho são questões essenciais, permite encontrá-los nas indústrias aeroespacial, aeronáutica, nuclear, petroquímica, náutica, automobilística e de veículos de competição. Essa posição de destaque, somente foi alcançada no final dos anos 60 graças ao desenvolvimento das fibras de carbono. Desde então, muitos trabalhos foram desenvolvidos com o intuito de prever o comportamento desse material ao 
trincamento, com a finalidade de melhorar as condições de processamento, o que pode fornecer maior confiabilidade a esse tipo de compósito quanto à resistência mecânica e à tenacidade.

Os métodos para estudar esse comportamento, se baseiam no estudo da fractografia quantitativa, feito através da observação da superfície de fratura que, se realizada com riqueza de detalhes, pode revelar o comportamento e resistência dos materiais submetidos a situações como carregamento cíclico, através da análise do comportamento e desenvolvimento de trincas.

As superfícies de fratura dos compósitos do tipo CFRP (Carbon Fiber Reinforced Polymer), apresentam peculiaridades únicas, inerentes a esse material, como a presença de arrancamento (pull-out) de fibras, onde parte delas fica exposta na superfície, gerando regiões com alta rugosidade devido a grande variação em altura, o que dificulta sua observação com os métodos usuais de microscopia. Em contrapartida, o conhecimento dessa distribuição em altura das fibras poderia, por exemplo, levar a um conhecimento mais preciso das energias envolvidas no processo de fratura e resistência das interfaces, levando ao aprimoramento do processo e das propriedades mecânicas desse material.

Os métodos de análise de superfície mais comumente utilizados atualmente usam o registro em duas dimensões, que permite apenas uma visão geral das áreas de fratura, perdendo todo tipo de informação que um conhecimento real da superfície poderia fornecer.

Para fazer um estudo mais detalhado dessas superfícies, o melhor método seria o conhecimento da rugosidade superficial, tomados ponto a ponto, com alta precisão no detalhamento, para permitir uma boa discriminação das alturas, que levaria a melhor quantificação dos mecanismos de fratura. Dessa forma, a simples observação deve evoluir para um mapeamento tridimensional da região, que embora seja um método muito utilizado em outras 
áreas, em especial na área médica, ainda é pouco explorado pelos pesquisadores da área de materiais.

Atualmente o direcionamento dos equipamentos para observação de superfícies está voltado para a nanotecnologia, onde a necessidade maior é poder quantificar elementos em escalas cada vez menores, tentando visualizar em grande escala, regiões ínfimas de matéria. Para alcançar essa finalidade, existe uma preocupação maior com a resolução horizontal, que vai permitir distinguir os "nanocomponentes" da imagem, não havendo o mesmo nível de interesse pela resolução vertical, que está relacionada com a rugosidade, a variação em altura da região estudada, que é sem dúvida o objeto de estudo mais importante para a caracterização dos fenômenos de fratura. Desta forma, uma maneira mais direta e prática de poder realizar uma reconstrução 3D, é aperfeiçoar métodos convencionais de observação, acessíveis a grande maioria dos pesquisadores, dentre eles a microscopia óptica e a eletrônica de varredura, associadas a um aplicativo específico de análise de imagens, que seja capaz de realizar uma reconstrução tridimensional de uma superfície.

Ao pensar na possibilidade de utilização dos analisadores de imagens disponíveis no mercado, a maior dificuldade é a impossibilidade de comparação de resultados, pois ao se confrontar uma medida realizada com determinado modelo, de determinada marca, com qualquer outro equipamento que não seja idêntico a ele, acrescenta imprecisões pela falta de padronização durante a programação. Mesmo para os equipamentos de mesma marca, mas com modelo diferente, não é confiável essa comparação devido a diferenças de aplicativos, onde uma atualização do software pode alterar algoritmos até então utilizados. Embora os aplicativos comerciais sejam adquiridos pelo usuário, a custos bem elevados, seus códigos não são abertos, o que faz que falhas e limitações de programação não sejam consideradas, podendo mesmo ser omitidas, e assim resultar em erros de análise dos resultados.

Levando-se em conta que as imagens adquiridas por microscopia correspondem a imagens aumentadas das imagens reais, qualquer erro de 
medida pode levar a desvios consideráveis para as escalas envolvidas. A padronização do método e a abertura do código fonte tenderiam a uma unificação no tratamento dos dados, que poderiam ser comparados, com seus limites fixados e, como conseqüência, qualquer melhoria em termos de inovação dos métodos empregados, poderiam ser anexados e abertos a qualquer usuário que por ele se interessasse.

Em síntese, para a realização desta tese, o grande desafio foi o de interconectar áreas distintas em um único trabalho. A preocupação em mente era a de conduzir o raciocínio a uma contribuição, para uma melhor avaliação sobre o comportamento mecânico dos materiais compósitos, através de fractografia quantitativa e encontrar na reconstrução tridimensional de superfícies de fratura um método factível para realizá-lo. Neste ponto, é bom ressaltar a opção por software abertos, de distribuição livre, que permitam a comparação e discussão dos resultados, além de mostrar claramente seus limites e revelar seu potencial de análise, permitindo que aperfeiçoamentos possam sempre ser implementados.

A exploração de recursos, nem sempre bem aproveitados, de equipamentos usuais de análise fractográfica associada a um software aberto, pode enriquecer em muito, a análise microestrutural de superfícies e contribuir para o detalhamento dessas regiões para uma melhor compreensão do comportamento mecânico e de propriedades importantes como resistência e tenacidade à fratura dos materiais. 


\section{Objetivo}

Este trabalho apresenta a proposta de um método para a realização de reconstrução tridimensional de superfícies de fratura, para materiais compósitos do tipo CFRP (Carbon Fiber Reinforced Polymer), utilizando equipamentos usuais de análise microestrutural, através da exploração de suas potencialidades, que pode ir além da simples aquisição de imagens.

Uma discussão sobre os procedimentos e limites durante o processo de aquisição de imagens é apresentada, e algumas sugestões para alterações da rotina são sugeridas para que o método possa ser utilizado em superfícies de qualquer material, independente de possuir ou não uma rugosidade bem comportada. 


\section{Revisão da Literatura}

O desenvolvimento deste trabalho engloba uma discussão sobre vários temas de ciência dos materiais: materiais compósitos, mecânica da fratura, fractografia e análise de imagens. Embora o conhecimento sobre cada um deles seja necessário para o entendimento do trabalho, é quase impossível encontrar todos reunidos em uma mesma discussão na literatura. A revisão bibliográfica será dividida entre esses tópicos para facilitar a visão global do trabalho, dentro do estado atual de desenvolvimento nesses campos.

\subsection{Materiais Compósitos}

As propriedades dos materiais compósitos dependem da maneira como cada um dos seus constituintes é incorporado a ele, tanto em termos quantitativos, quanto em termos qualitativos. Artigos da literatura buscam entender como essa composição afeta as propriedades do material compósito.

Tomita et al. ${ }^{(1)}$ fazem uma comparação entre compósitos de matriz epóxi reforçados com dois tipos de fibras de carbono, que apresentam diferentes propriedades individuais: 3,5 e 5,5 GPa de tensão de fratura por tração. $\mathrm{Na}$ presença de entalhe, o compósito reforçado com as fibras de 5,5 $\mathrm{GPa}$ apresenta um aumento na tensão aplicada em tração e uma diminuição na resistência a fratura, se comparado com o compósito com fibras de 3,5 GPa. O perfil de fratura tem a forma de um zig-zag para o compósito com fibras de 3,5 $\mathrm{GPa}$, perpendicular a direção de carregamento, enquanto para o outro compósito a fratura é interfacial, entre fibra e matriz, paralela a direção de carregamento. O processo de fratura do compósito de 3,5 GPa consiste de uma fratura frágil e de arrancamento ("pull-out") das fibras, enquanto que para o outro (5,5 GPa) foi observado o descolamento das fibras da matriz. Uma 
explicação mais detalhada e alguns esquemas sobre os micromecanismos de fratura de materiais compósitos são apresentados no apêndice "A".

Um esquema sobre o processo de fratura para o compósito reforçado com fibras de 3,5 GPa é apresentado na figura 1a, baseado em propriedades físicas e assumindo num primeiro instante que tanto a fibra quanto a matriz epóxi se deformam uniformemente até que ocorra a fratura.

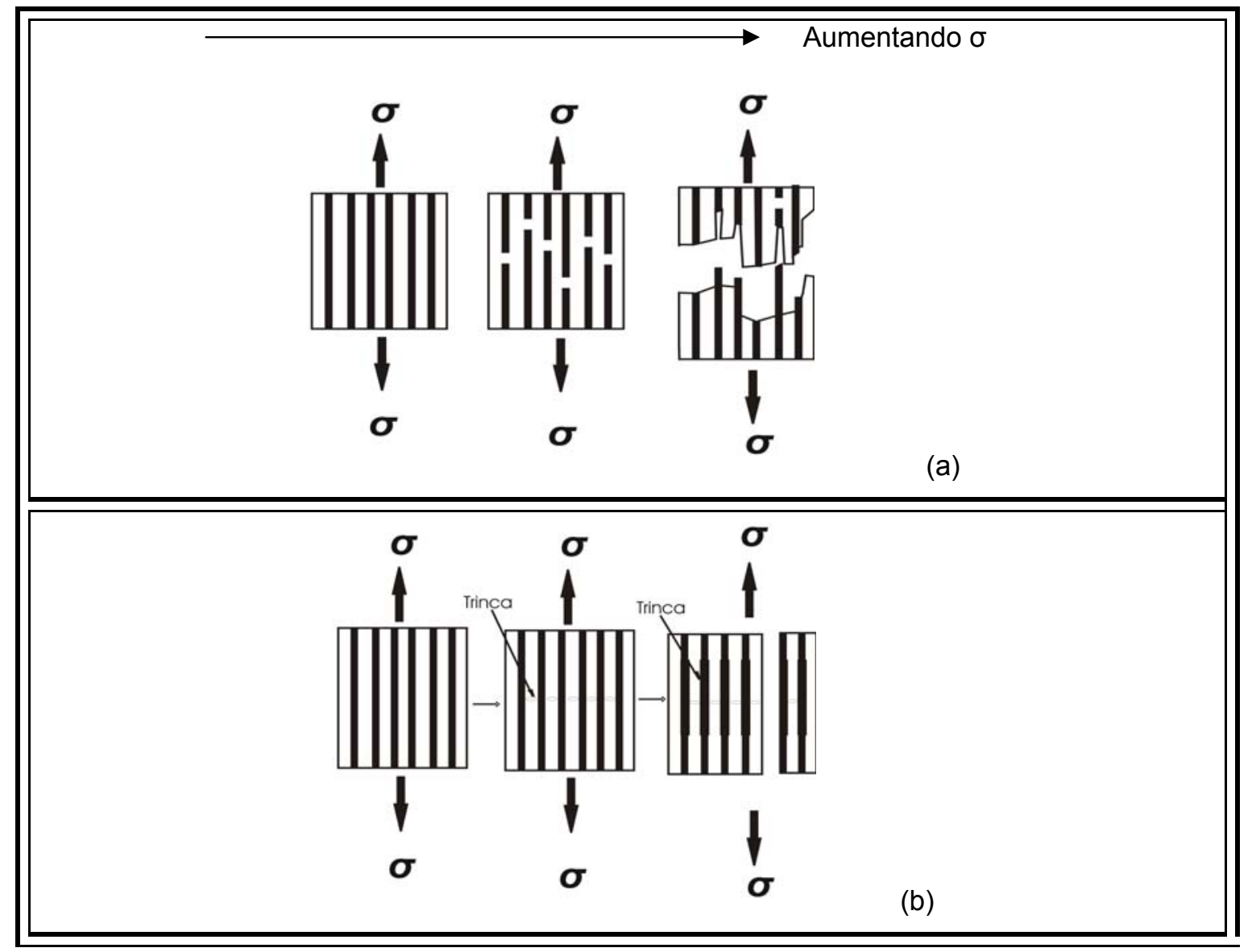

Figura 1: Esquema para o processo de fratura do compósito reforçado com fibra de carbono de: (a) 3,5 GPa e (b) 5,5 GPa (Y. Tomita and M. Tempaku).

Microtrincas são iniciadas com a fratura das fibras, porque a deformação até a fratura da fibra é menor que a da matriz. Com a diminuição do tamanho das fibras há a ocorrência de uma tensão de atrito na interface entre fibra e 
matriz. Se essa tensão for alta, as microtrincas formadas pela fratura frágil das fibras se estendem até a matriz e, em caso contrário, ocorre a formação do arrancamento das fibras pela falta de coesão entre fibra e matriz.

A diferença dos micromecanismos de fratura para o compósito reforçado com fibras de 5,5 GPa (figura 1b), baseado nas propriedades mecânicas e em fractografias e, partindo do pressuposto que fibra e resina se deformam uniformemente até que a fratura ocorra, são descritos da seguinte maneira: microtrincas são iniciadas pela fratura da resina epóxi, pois a tensão de fratura é menor que a das fibras. Nesse caso, o campo de tensões desenvolvidos na interface matriz-trinca-fibra deve ser considerado.

O resultado dos testes de tração, em amostras com entalhe em "V", é a ocorrência de fratura interfacial, nos dois compósitos. A diferença, observada em tensão e no perfil de fratura dos dois compósitos, é conseqüência do resultado das diferenças na resistência à fratura em tração, na deformação das fibras e na resistência de adesão entre fibras e a matriz. Desta forma, a fratura à tração de compósitos de matriz epóxi reforçado com fibras de carbono contínuas é fortemente afetada pela resistência das fibras.

Um estudo sobre o efeito da sequência de empilhamento de lâminas nas propriedades mecânicas e o comportamento a fratura é apresentado por Marioka et al. ${ }^{(2)}$, para materiais compósitos CFRP, reforçado por fibras de carbono contínuas. Neste estudo, após testes de tração, flexão lenta em três pontos e charpy instrumentado, através de comparação de amostras com e sem entalhe, observa-se que a propagação de trinca e o tipo de fratura observada, dependem da seqüência de empilhamento do compósito. Os danos produzidos são característicos da orientação das fibras nas camadas superior e inferior do compósito. Assim, o empilhamento determina tanto as propriedades quanto os tipos de falha que podem ocorrer no material.

A distância média entre vizinhos mais próximos é uma classe de descritores espaciais usada em ciência dos materiais e possui um papel muito 
importante na resposta mecânica e no comportamento a falhas de compósitos uniaxiais. Tewari et al. ${ }^{(3)}$ propõem uma fórmula básica para o cálculo da distância média do vizinho mais próximo para fibras de mesmo tamanho em compósitos uniaxiais e comparam os resultados com o de outros métodos, mostrando a confiabilidade da fórmula proposta.

As propriedades de impacto e os efeitos da pré-impactação nas propriedades de impacto final de compósitos reforçados com fibras de carbono foram estudadas por Smmazçelik et al. ${ }^{(4)}$ onde se observa que tanto a energia de impacto quanto o número de impactos são parâmetros fundamentais, ocorrendo a diminuição da energia de impacto com o número de impactos para a falha. Amostras pré-impactadas mostram um comportamento diferente à fratura e, sua morfologia pode ser comparada com amostras com fratura única, sem pré-impacto. As linhas neutras, que comparam as somas de tração e de compressão, se deslocam através da zona de tensão com o aumento do número de pré-impactos, talvez devido à ocorrência de deformação plástica.

$\mathrm{Na}$ tentativa de melhorar a tenacidade de materiais compósitos, Ratna ${ }^{(5)}$ estudou compósitos reforçados tanto com fibras de vidro como de fibras de carbono, e de uma blenda epóxi/HBP (hiperbranched polymer) como matriz. Comparando os resultados de testes de flexão e de resistência a impacto, verifica-se que a incorporação de HBP à resina epóxi resultou em um aumento significativo na tenacidade dos compósitos reforçados com fibra de vidro, com ligeira diminuição de resistência a flexão. Porém, nenhum desses efeitos foi observado para os compósitos reforçados com fibras de carbono.

A influência de alguns fatores de processamento nas propriedades de flexão de materiais compósitos unidirecionais, reforçados com fibras de carbono unidirecionais, foi estudado por Sudarisman ${ }^{(6)}$. Propriedades como concentração de resina epóxi, pressão de compressão e tempo de retenção aplicado durante a cura em autoclave a $120^{\circ} \mathrm{C}$, influenciam a resistência à flexão durante ensaio de flexão em três pontos. Os testes foram realizados para uma variação entre $45-65 \%$ em peso de resina, uma pressão compressiva 
entre 0,25-1,25 MPa e um tempo de retenção de 20-40 min. A melhor resistência foi alcançada com uma concentração de $50 \%$ em peso de resina epóxi, 1,0 MPa de pressão compressiva e um tempo de retenção de $30 \mathrm{~min}$. $\mathrm{O}$ módulo máximo obtido foi de $72,9 \mathrm{GPa}$ e a máxima fração volumétrica de $62,5 \%$. As imagens utilizadas para análise foram adquiridas por microscopia óptica.

A quantificação da distribuição de fibras contínuas em compósitos unidirecionais foi realizada por Requena et al. ${ }^{(7)}$, através de micrografias "syncrotron" (microtomografias) em compósitos de matriz metálica e polimérica, para avaliar o grau de alinhamento das fibras, que influencia as propriedades de compósitos reforçados com fibras contínuas. Os volumes reconstruídos obtidos, foram analisados para caracterizar a distribuição de reforço com relação a fração volumétrica local e a orientação do reforço.

A metodologia utilizada permitiu reconhecer diferentes feixes de fibra e fração volumétrica local dentro desses feixes. Regiões com pequena fração volumétrica local, menor que $20 \%$, tendem a formar canais paralelos ao eixo das fibras, revelando os feixes em ambos os compósitos. Regiões com densidade maior que $60 \%$ em volume, são homogeneamente distribuídas e formam aglomerados no compósito de matriz metálica, enquanto que para o compósito de matriz polimérica ocorre a formação de canais verticais dentro dos feixes das fibras. Fibras localizadas nos contornos dos feixes exibem desorientação $\left(<20^{\circ}\right)$. Os compósitos CFRP mostram ter uma orientação mais homogênea das fibras, mesmo entre feixes diferentes.

\subsection{Mecanismos de Fratura de Compósitos do tipo CFRP}

Embora as propriedades dos materiais compósitos possam variar de acordo com o processo de fabricação, como em qualquer outro material, os 
modos de fratura são características únicas para os compósitos do tipo CFRP, e serão discutidos a seguir.

A preocupação com os mecanismos de fratura vai desde a associação desses mecanismos com os já existentes para outros materiais, adequando a nomenclatura para os materiais compósitos, até o estudo dos possíveis mecanismos inerentes a esse tipo de compósito, e de que forma calcular as energias envolvidas nos processos.

Johannesson et al. ${ }^{(8)}$ determinaram as principais características da superfície de fratura que podem levar a indícios dos mecanismos de fratura predominantes, em laminados grafite/epóxi. Essa superfície contém áreas ricas e pobres em resina, onde são encontradas marcas e descolamento de fibras, respectivamente. Neste trabalho, consideram a delaminação o principal mecanismo de fratura para laminados com fibras dispostas em ângulos menores que $45^{\circ}$. A formação de serrilhados característico desse material depende do estado de tensões e do modo de falha, sendo formados ao longo da direção das tensões principais de tração.

Morioka et al. ${ }^{(9)}$ estudaram as propriedades de fratura para compósitos CFRP para aplicações aeroespaciais e verificaram a correlação entre valores de tensão e energia de fratura, com a variação de temperatura. Para laminados $0^{\circ} 0^{\circ}$, durante variação de temperatura entre $20^{\circ} \mathrm{C}$ e $230^{\circ} \mathrm{C}$, ocorre uma diminuição na tensão de fratura, mas a energia de fratura por flexão não apresenta dependência com a temperatura. Isto se deve ao fato de que as trincas se iniciam facilmente no lado compressivo, com ocorrência de delaminações entre placas adjacentes do laminado e, como a fratura cisalhante ocorre por toda a amostra, a energia de fratura de flexão independe da temperatura.

Para laminados $0^{\circ} / 90^{\circ},+45^{\circ} / 45^{\circ}$ e $0^{\circ} / \pm 45^{\circ} / 90^{\circ}$, a tensão de fratura por flexão tem pouca dependência com a temperatura até que diminui repentinamente a $230^{\circ} \mathrm{C}$, enquanto ocorre um aumento na energia de fratura 
de flexão com o aumento de temperatura. A pouca dependência com a temperatura é atribuída ao fato de que a primeira trinca ocorre a $180^{\circ} \mathrm{C}$. O aumento da energia de fratura é atribuído à mudança no modo de propagação da trinca dos laminados, de fratura interfacial entre fibras e a resina epóxi, envolvendo a quebra da fibra, para a fratura cisalhante das fibras, conforme o aumento de temperatura.

Durante discurso em uma conferência sobre falhas em materiais compósitos, Beaumont ${ }^{(10)}$ argumenta que, quando a vida humana depende da integridade estrutural como um requisito essencial do projeto, são necessários 10000 cupons de teste do material por configuração de laminados de compósitos para avaliar uma estrutura, mais carregamento no limite de falhas em partes específicas, para alcançar uma certificação de navegabilidade aérea de aeronaves. Prever com sucesso o comportamento mecânico do material e o desempenho do projeto de estrutura requer informações detalhadas de todos os possíveis mecanismos de falha, cobrindo um largo espectro da escala de dimensões, sobre toda a sorte de condições operacionais. Entender o comportamento estrutural em vários níveis dimensionais requer destreza na manipulação de ferramentas projetadas para esse trabalho: as ferramentas de análises empíricas (modelagem matemática e contínua). Usar essas ferramentas para determinar equações constitutivas, auxilia no conhecimento das regras de comportamento do material.

O uso de métodos experimentais associados com técnicas analíticas apropriadas, incluindo modelagem física, e a evidência direta de trincamento e processo de fratura, também objetiva a identificação de limites permissíveis no desempenho seguro do material, e na durabilidade do componente. Com o advento de computadores potentes e software comprados por preços razoáveis, é possível implementar modelos físicos e soluções computacionais, como aplicativos de uso livre ou integrado em projetos comerciais de elemento finito. De qualquer forma, uma implementação bem sucedida de modelos físicos ou simulação requerem conhecimento do próprio fenômeno. 


\subsection{Fractografia}

O estudo das superfícies de fratura, por meio de fractografia, dos materiais compósitos do tipo CFRP assume um caráter único pelas características inerentes ao processo de fratura ser muito distinto do até então observado em outros materiais. Há a necessidade de tentar encontrar aspectos semelhantes com os estudos já realizados, ou mesmo caracterizar os novos aspectos com cuidado especial na nomenclatura dada a cada fenômeno.

Em um de seus artigos, Purslow ${ }^{(11)}$ faz uma correlação entre a fractografia de materiais metálicos e a de materiais compósitos, e tenta adequar a terminologia empregada para os metais, aos fenômenos observados nos materiais compósitos. Algumas vezes, uma característica pouco parecida com as que ocorrem nos metais, tem origem totalmente diferente e o termo utilizado para sua definição se torna inexpressivo ou até mesmo sem sentido. Um bom exemplo disso ocorre quando há propagação da trinca, em uma área relativamente grande na resina do material compósito, gerando linhas na direção de crescimento da trinca em planos levemente diferentes. A fractografia se assemelha aos padrões de rio em metais, mas os mecanismos envolvidos são totalmente diferentes.

Para analisar as falhas estruturais em materiais compósitos, é importante não só relacionar a fractografia aos mecanismos de fratura, mas saber descrever essa característica de fratura sem ambigüidade, entendendo precisamente o seu significado para poder determinar a maneira como ocorre a fratura, a direção de propagação e por fim a origem e a seqüência da falha estrutural. O fenômeno de "pull-out" é uma das mais importantes características de fratura "não-frágil" e, para conhecer e entender a natureza e a origem dessa fratura, através de fractografias, os passos principais são os seguintes: a observação de algumas das várias características da fratura e a influência de alguns parâmetros, como a resistência da interface fibra/matriz. 
Uma análise sobre a técnica de caracterização, usando apenas um microscópio óptico de baixa potência é apresentada por Purslow ${ }^{(12),}$ para caracterizar fraturas e falhas seqüenciais de uma típica estrutura aeroespacial. Com o uso apenas dessa ferramenta, mostra que pode determinar com sucesso a causa inicial da falha final sem a necessidade de recorrer a uma análise em microscopia eletrônica de varredura.

A explicação das características fractográficas de materiais compósitos levam Purslow ${ }^{(13)}$ a estabelecer as maneiras como elas ocorrem. Uma das mais interessantes é a formação das cúspides em matrizes poliméricas, que ocorrem quando uma faixa do material fica sujeito à tensão cisalhante. As falhas irão aparecer como uma série de fraturas de micro tensões no plano da faixa cisalhante, mas que individualmente são normais a componente da tensão decomposta. Com o aumento da tensão cisalhante, o número de trincas aumentará e individualmente irão se alongar e suas curvaturas se aproximarão do limite da banda cisalhante. A máxima tensão cisalhante irá ocorrer ao longo da linha de trincas quando essas falhas coalescem. Se ocorrer a separação final, geralmente ao longo de um dos lados da banda cisalhante, as superfícies de fratura, ou apenas uma delas, exibe a característica conhecida como cúspide. Um esquema desse processo é apresentado na figura 2 .

Muitas outras características de superfícies de fratura de materiais compósitos são apresentadas, detalhando a origem e a causa da falha para essas estruturas. Esses resultados se aplicam a todos os tipos de compósitos de matriz epoxi reforçado com fibras.

Segundo Shikhmanter et $\mathrm{al}^{(14)}$, para um material multidirecional, cada camada possui as mesmas características que a de um material unidirecional, mantendo a mesma direção das fibras. A principal característica da fratura em compressão axial é a presença de microflambagem das fibras, e uma aparência distinta de áreas de fratura de compressão e de tração, respectivamente na superfície de fratura das fibras individuais. Em seu 
trabalho, amostras unidirecionais submetidas à tensão, compressão e flexão estão sempre acompanhadas por trincamento longitudinal na direção das fibras, e nos contornos das camadas, que se caracterizam por serem trincas de delaminação. Como característico dessa região aparecem fibras expostas ou impressão suaves dessas trincas na matriz.

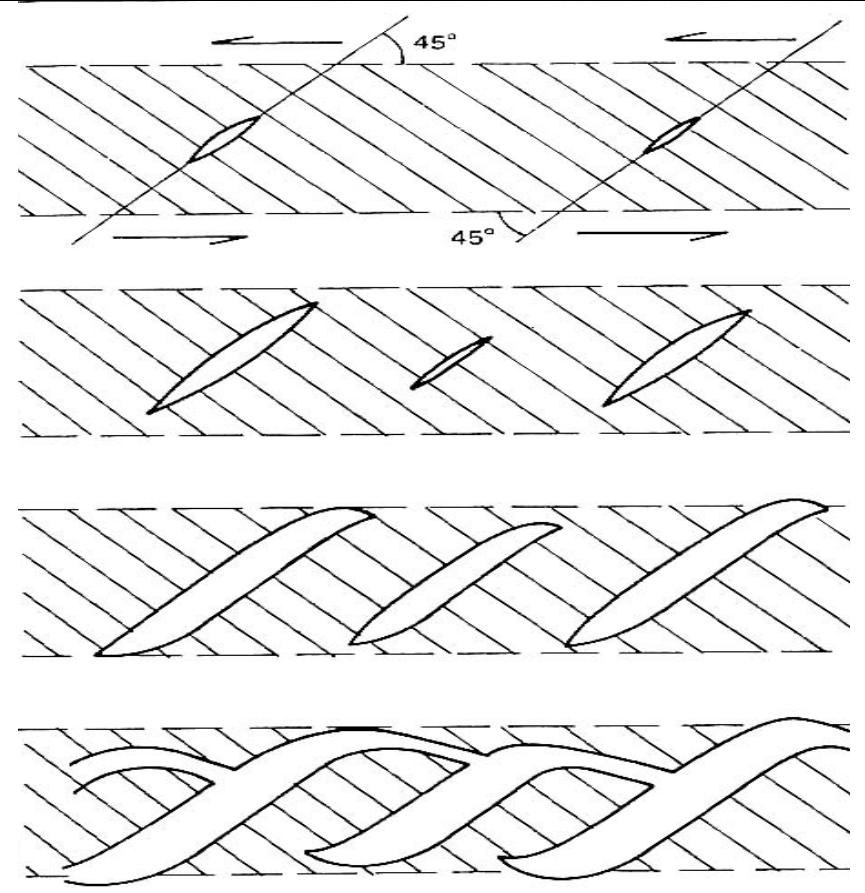

Figura 2: Esquema de formação de falha por cisalhamento na matriz polimérica e formação de "cuspides", com o aumento da tensão cisalhante. (D. Purslow).

As amostras carregadas transversalmente apresentam falhas em planos perpendiculares a direção da carga aplicada. Algumas áreas são caracterizadas por apresentarem aspectos típicos de rios (figura 3), feitos por um fluxo de linhas finas que podem ser vistas em alto aumento. As superfícies de fratura de compressão, tanto transversal quanto axial, apresentam áreas repletas de fragmentos de fibras quebradas e de resina formadas por danos após falha principal. Falhas em teste de cisalhamento são devidas às trincas se propagando na direção das fibras, principalmente nas regiões interlaminares 
e em uma menor extensão dentro das camadas. As amostras, quando submetidas a testes de absorção de misturas $\left(120^{\circ} \mathrm{C}\right.$ após exposição anterior por dois meses, em um ambiente a $70^{\circ} \mathrm{C}$ e $95 \%$ de umidade relativa), mostram um aumento na fração de falha que ocorre na interface fibra/matriz.

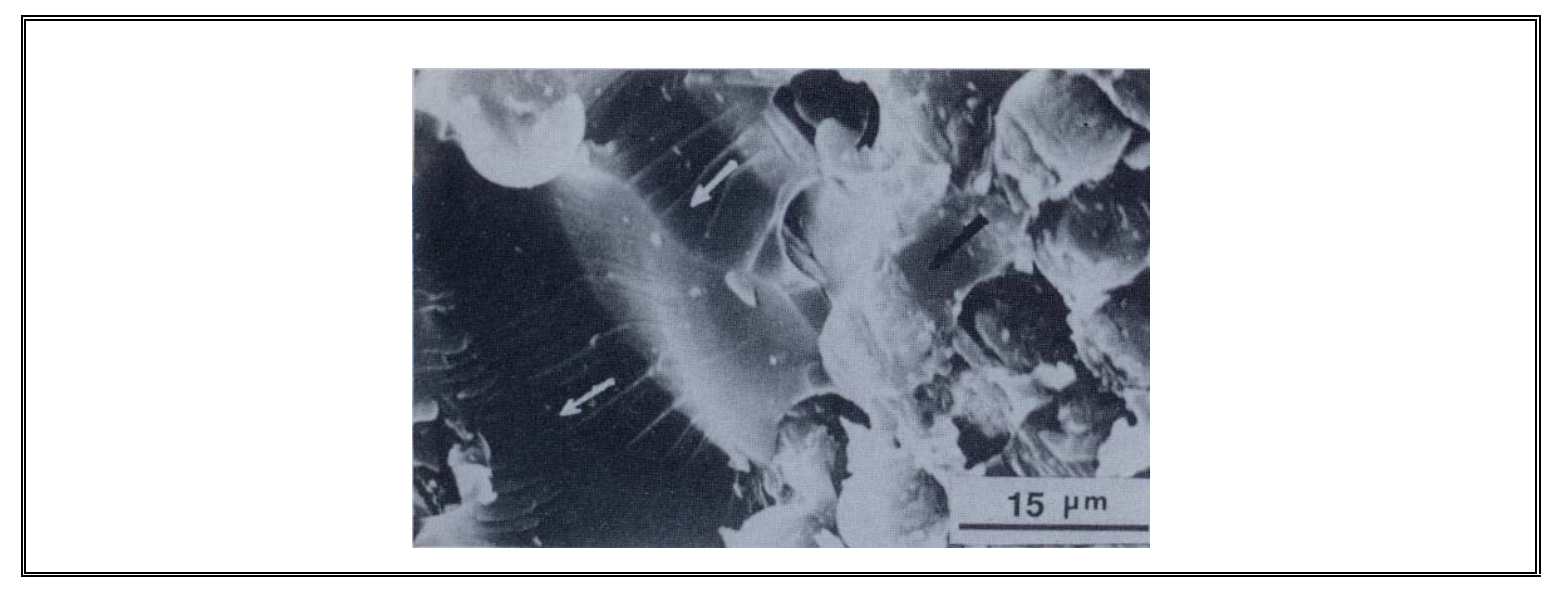

Figura 3: Fratura compressiva, em região rica em resina, com indicação da direção de propagação (Shikhmanter, I. and Eldror, B. Cina)

Em continuação ao seu trabalho, Shikhmanter et al ${ }^{(15)}$, fazem o mesmo estudo para materiais multidirecionais e compara os resultados com os unidirecionais. Eles afirmam que os materiais multidirecionais possuem muito das mesmas características fractográficas, iguais aos materiais unidirecionais para as mesmas direções das fibras.

O dano da delaminação foi a característica que mais chamou a atenção, ocorrendo sempre onde quer que haja uma diferença em orientação entre as camadas, presumivelmente devido a maior deformação interplanar relativa gerada durante o carregamento. A delaminação parece ocorrer em dois estágios: a formação de microtrincas na matriz seguida pela falha total, aparentemente simultânea da matriz, através da formação de cúspides e, a exposição das fibras. Esses resultados foram observados em fractografias de 
superfícies delaminadas sem restrição da tensão aplicada e da orientação relativa de camadas adjacentes.

As características da interface fibra/matriz, em compósitos reforçados com fibras unidirecionais, influenciam fortemente suas propriedades. Embora muitos métodos para medir a resistência ao cisalhamento tenham sido desenvolvidos e aplicados a matrizes poliméricas, metálicas ou cerâmicas, para diferentes tipos de fibras, poucos autores consideram a distribuição de comprimento de "pull-out" de fibras na superfície de fratura. A medida desses comprimentos em relação à fratura da matriz, como uma referência plana, é aplicável somente para matrizes de alta rigidez (cerâmica, por exemplo), contendo um baixo volume de fibras, onde o caminho da trinca está próximo ao plano desde que a distribuição de resistência das fibras não influenciem o caminho da trinca. Para matrizes plásticas ou metálicas, o caminho da trinca é usualmente uma superfície mais rugosa, sendo necessário uma aproximação diferente para avaliar a distribuição de altura de quebra das fibras.

Lienkamp et al. ${ }^{(16)}$, através de um método desenvolvido para determinar o perfil de tensão na ponta da trinca, a resistência da fibra in situ, o comprimento crítico e as tensões cisalhantes das fibras em uma matriz, mostra que a análise da diferença de altura de quebra, fornece resultados bem reprodutíveis em tempo muito curto. Durante as observações concluiu que diferentes mecanismos de falha ocorrem em compósitos com matriz de baixa (cerâmica) e alta deformação a fratura (metálica e plástica). Para cerâmica, o caminho da trinca é dominado pela matriz e as fibras são arrancadas da matriz em relação ao plano da trinca na direção do comprimento de arrancamento. Para matrizes metálicas e poliméricas a trinca é dominante na fibra e pulam de fibra em fibra resultando em uma diferença de altura de quebra. Os compósitos de matriz metálica mostram aumento de tensão não linear das fibras na ponta da trinca. A avaliação da distribuição da diferença de altura de quebra é um avanço sobre as técnicas anteriores para caracterizar o comportamento mecânico dos compósitos a base de fibras contínuas. 


\subsection{Análise de Imagens}

Para entender as falhas que envolvem a fratura e determinar 0 processo de fratura em materiais diversos, é necessário aperfeiçoar os métodos de caracterização da topografia das superfícies de fratura. $\mathrm{O}$ caso específico dos materiais compósitos CFRP, cuja superfície de fratura apresenta grandes diferenças em altura, a descrição da sua rugosidade é fundamental para seu entendimento.

Brooks et al. ${ }^{(17)}$ apresentam considerações sobre os procedimentos mais adequados para a utilização do MEV, notadamente importante na análise fractográfica devido, principalmente, a três características desse equipamento: alta resolução, grande profundidade de campo e a facilidade na obtenção de informações químicas através de análise de raios-X gerado pelos elétrons. A revisão apresentada no artigo relembra as limitações e precauções tanto na obtenção da imagem quanto na análise química e na interpretação e uso em fractografia.

A precisão no aumento de uma imagem MEV é de cerca de $5 \%$. Ao se fazer medidas na superfície de fratura de uma imagem, as dimensões projetadas são obtidas dividindo as medidas da imagem pelo aumento. Um feixe ("spot") de menor tamanho produz imagens melhor resolvidas, e revela detalhes mais finos. Se uma superfície é inclinada, mais elétrons se encontram dentro da profundidade de escape, como no esquema apresentado na figura 4 , e assim mais elétrons são detectados. Portanto, faces em certo ângulo com o feixe de elétrons, emitirão muito mais que aquelas que estejam mais próximas a normal desse feixe, o que afeta o contraste da imagem. As faces mais voltadas ao detector são mais brilhantes e, uma imagem será melhor se obtida com elétrons secundários, pois os elétrons de baixa energia provenientes das faces voltadas à direção ao detector, ou mesmo escondidas, serão atraídos a ele. Os elétrons retro-espalhados provenientes de uma profundidade maior, 
trazem informações do material em uma profundidade maior da superfície do que os elétrons secundários.

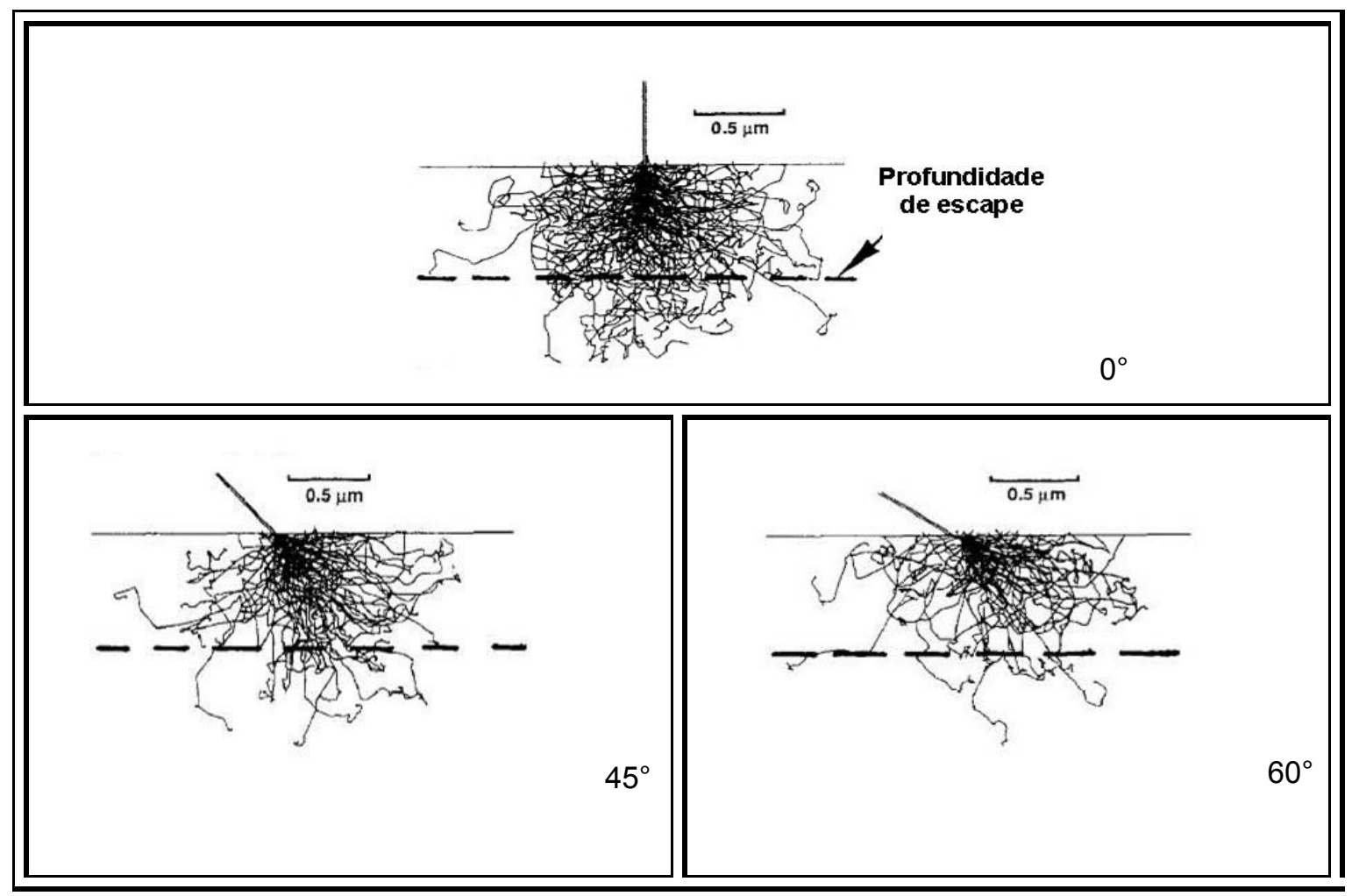

Figura 4: Esquema sobre o aumento do número de elétrons detectados, conforme o aumento na inclinação de amostras em MEV (Brooks, C. R. e McGill, B. L.).

A qualidade da imagem está relacionada com as características que afetam a resolução. Assim, menor voltagem e menor corrente do feixe permitem uma menor penetração, que produzirá uma imagem de resolução superior, providenciando que o nível sinal-ruído não seja afetado significativamente. Uma abertura menor da lente objetiva também aumentará a qualidade da imagem por produzir um menor tamanho de diâmetro do feixe ("spot"). Se elétrons são conduzidos na superfície, ocorre um carregamento dessa superfície que distorce a imagem. Esse efeito pode ser reduzido obtendo-se imagens com uma baixa voltagem, e fazendo o recobrimento da superfície. É importante notar que os cristais de ouro, depositados durante o 
recobrimento, possuem cerca de $200 \mathrm{~nm}$ de lado a lado, portanto detalhes mais finos que isto serão mascarados pelo filme de ouro do recobrimento.

A imagem obtida por MEV é aproximadamente uma projeção bidimensional da superfície, dando uma ilustração incorreta da sua topografia. Para a maioria das observações fractográficas, isso não é uma limitação, pois a aparência geral da superfície de fratura é preservada, e isto pode ser tudo o que se requeira. Entretanto, a profundidade de campo da imagem pode minimizar a percepção da profundidade real. Estereovisão pode ser usada para medir a distância de características da superfície de fratura acima da superfície.

A fractografia quantitativa envolve a aplicação de técnicas geométricas para colocar a topografia da superfície de fratura em termos quantitativos envolvendo comprimento, área, orientação, etc. A topografia da superfície de fratura é ditada pelo processo de fratura, e assim, sua aparência fornece informação sobre os mecanismos de fratura. O mecanismo e o caminho da trinca são grandemente influenciados pela microestrutura, e no caso de materiais poliméricos, também pelo arranjo molecular, e os detalhes dos mecanismos de fratura não são necessariamente bem estabelecidos, formando uma superfície de fratura com topografia complexa.

Atualmente o estudo de superfícies de fratura vem sendo incrementado pela implemantação de geometria fractal, numa tentativa de desenvolver correlações complementares entre microestrutura e mecanismos de fratura ${ }^{(18)}$. Pelo fato da fractografia qualitativa não estar apta a distinguir em detalhes essas características da superfície de fratura, a caracterização fractal vem sendo aplicada como um método importante em fractografia. A fratura é um fenômeno complexo, o que torna difícil a tarefa de desenvolver uma teoria completa para explicar satisfatoriamente as tendências aparentes observadas experimentalmente para diferentes sistemas de ligas e classes de materiais. Mecanismos de fratura podem ter um papel importante na interpretação correta da relação entre o incremento da dimensão fractal, como medida de 
rugosidade de fratura, e algumas propriedades de ligas metálicas, tal como a tenacidade.

O conceito original de geometria fractal, desenvolvido por Mandelbrot, é muito utilizado em ciência dos materiais, especialmente na descrição quantitativa de microestruturas como contornos de grão, padrões de discordâncias e superfícies de fratura com características diferentes, onde a rugosidade é o maior objetivo da fractografia quantitativa. Para Li et al. ${ }^{(19)}$, a rugosidade da superfície de fratura deve ser proporcional a energia de impacto e, com base em resultados experimentais, mostra que a dimensão fractal $\left(D_{S}\right)$ para superfícies de fratura pode ter relações diferentes com as propriedades mecânicas de materiais para diferentes tipos de fratura, chegando mesmo a afirmar que a rugosidade da superfície de fratura está fundamentalmente relacionada ao tamanho de grão,sendo que quanto maior o tamanho de grão, maior o diâmetro da cavidade dúctil "dimple" e menor a rugosidade da superfície de fratura. Desta forma, a microestrutura de materiais deve ser considerada quando se deseja relacionar dimensão fractal com as propriedades mecânicas dos materiais.

Horovistiz et al. ${ }^{(20)}$ apresentam um exemplo de melhoria em fractografia quantitativa através de processamento de imagens digitais e microscopia óptica. A primeira técnica é um método para medidas de dimensão fractal de perfis de superfícies, revelando o caráter multifractal da fratura, onde não foi observada uma clara relação às energias Charpy devido à ductilidade, heterogeneidades microestruturais e características de carregamento dinâmico em regiões próximas ao entalhe. A segunda técnica fornece o mapa de elevação de superfícies de fratura pela extração de regiões em foco para cada figura de uma série de imagens, obtidas em posições de foco sucessivas, permitindo assim computar a rugosidade da superfície. A reconstrução por foco estendido é utilizada para explicar o comportamento da rugosidade ao longo da superfície de fratura. Dessa forma, essas técnicas baseadas em microscopia óptica, além de apresentarem um baixo custo inerente, são muito interessantes para as investigações de falhas. 
Ammann et al. ${ }^{(21)}$, apresentam um método para melhorar a caracterização da superfície de fratura através de uma reconstrução tri dimensional. A técnica proposta é uma maneira muito eficiente para extrair informações 3-D de um par estéreo de micrografias, que permite a reconstrução de superfícies de fratura com alto nível de resolução, cujo resultado é um mapa de elevação, que representa a topografia real da superfície. Através do uso de ferramentas do programa é possível visualizar o resultado em vários ângulos de observação, onde perfis podem ser extraídos do mapa de elevação, em várias direções, permitindo a determinação de parâmetros topológicos específicos.

Baseado em técnicas tradicionais de metalografia, Kral et al. ${ }^{(22)}$ fazem uma reconstrução 3D de amostras de três diferentes ligas de aço, produzindo importantes critérios para avaliação microestrutural, utilizando a técnica de seccionamento serial da superfície. Melhoramentos já estabelecidos para técnicas de análise 3D resultaram em remoção semi-automática de material, aquisição de imagens digitais e visualização de reconstrução tridimensional usando avanços computacionais, tanto em hardware quanto em software. Uma maneira de conferir segurança ao método foi o acompanhamento do tamanho das marcas de indentações de microdureza para ajudar no subseqüente alinhamento das imagens e calibrar a profundidade de material removido.

Embora este método possa atender as necessidades de análise de muitos materiais, é importante ressaltar que o seccionamento serial de superfície não é adequado aos materiais compósitos do tipo CFRP, pela impossibilidade do manuseio da amostra, como usualmente é realizado em materiais metálicos. Os processos de embutimento e desbaste são inviáveis quando se deseja determinar a rugosidade de um material a base de resina epóxi, e reforçada com fibras longas de carbono, pois comprometem a integridade do material. 
$\mathrm{O}$ artigo de Cheng et al. ${ }^{(23)}$, referente a reconstrução tridimensional de imagens de pares estéreos em microscópio eletrônico de transmissão (MET), traz uma discussão sobre o alinhamento e a comparação de imagens para realizar a reconstrução 3D. O processo computacional, que se divide em três partes principais: a representação de características, a comparação das regiões de interesse e o refinamento das disparidades de projeção encontradas com a inclinação das características, foi implementado em uma maneira baseada em multi-resolução, em estratégia do detalhamento partindo do mais grosseiro para o mais fino. Segundo o autor, uma extensão natural da reconstrução com pares estéreos seria uma reconstrução 3D com múltiplas imagens $(>2$ ), que poderia eliminar algumas das limitações impostas pela visão do par estéreo.

O processamento digital e a análise de imagens podem melhorar a fractografia quantitativa devido ao desenvolvimento de hardware e software para computação gráfica e vídeo. Em seu artigo, Hein $^{(24)}$ apresenta uma solução em termos de programação macro, com distribuição livre, para análise de fractografia quantitativa por meio de par estéreo de imagens MEV. Segundo o autor essa nova abordagem apresenta vantagens tais como a redução do tempo de aquisição de dados, melhoria na precisão e reprodutibilidade, e uma conexão perfeita com os novos conceitos de microscopia digital. Como o processamento é baseado em microscopia, os parâmetros de imagem como voltagem do feixe e resolução das imagens são fatores importantes na qualidade da reconstrução de mapas de elevação. Alguns limites sobre esses parâmetros são discutidos no trabalho como a voltagem do feixe eletrônico durante a aquisição das imagens, ou mesmo os limites para a ampliação das imagens, que permitem a introdução de distorções geométricas. Para o autor, ao se fazer análises com par estéreo, uma boa qualidade das imagens nem sempre apresenta a melhor aparência.

Um programa preliminar para reconstrução 3-D de superfícies rugosas, apresentado por Pouchou et al. ${ }^{(25)}$, usando um par de imagens estéreo de MEV, realiza operações opcionais com as imagens, antes da reconstrução 
propriamente dita. São operações sucessivas, de mixar imagens baseado em retificações, com parâmetros geométricos, alinhamento automático e comparando por correlação, características linha a linha, a fim de determinar as disparidades em cada pixel e reconstruir um mapa de elevações. A operação de comparação de características pode ser feita através de um algoritmo de programação dinâmica ou através de comparações em um esquema de correlação. A maior vantagem do par estéreo é que permite observar campos maiores que $100 \mu \mathrm{m}$ e medir elevações maiores que $10 \mu \mathrm{m}$. Entretanto, a abordagem mais promissora é adquirir, em vez de apenas duas imagens do par estéreo, um conjunto de múltiplas imagens (de preferência 5) e um conjunto de pontos extraído dessas imagens para realizar auto-calibração do sistema total de imagens. Após a auto-calibração, o confronto linha a linha das características pode ser feito selecionando um confronto possível, e completando com uma interpolação algorítmica. A associação de imagens de um par estéreo em MEV, cuidadosamente adquiridas com um avançado software para reconstrução 3-D, certamente dará a microscopistas e cientistas de materiais uma ferramenta poderosa para a caracterização quantitativa de superfícies rugosas em amplo intervalo de escalas.

Kuroda et al. ${ }^{(26)}$ apresentam um novo sistema para a reconstrução de topografia tridimensional em micrografias estereoscópicas em MEV, onde através de deslocamentos relativos entre pontos correspondentes, medidos por confronto de área, é possível calcular elevações de toda a superfície, com base em princípios estéreo-fotogramétricos e modelos digitais de elevação das superfícies investigadas. Um ponto interessante do trabalho é a introdução de uma equação para determinar a resolução do modelo de elevação. Para os autores, o principal problema de uma reconstrução automática com par de imagens estéreo, recai sobre a dificuldade de encontrar pontos correspondentes nas duas superfícies, ou seja, identificar pontos que são as projeções do mesmo objeto na amostra. 


\section{Materiais \& Métodos}

Para realizar a reconstrução tridimensional da superfície de fratura do material compósito foram utilizadas várias amostras de compósito CFRP, tanto unidirecionais, quanto multidirecionais. Além dessas amostras, outros materiais, tais como aço, ligas de cobre e de alumínio, também foram utilizados para a aquisição das imagens de superfície de fratura.

Os compósitos utilizados neste trabalho são constituídos de matriz de resina epóxi DGEBA (Diglicidil de Bisfenol A) e fibra de carbono HT de 6000 filamentos, os quais foram fabricados e ensaiados por $G$. Marinucci ${ }^{(27)}$, que forneceu varias amostras para a realização deste trabalho. As amostras de compósito unidirecionais foram retiradas de corpos de prova para ensaio de tração longitudinal, com espessura aproximada de $2 \mathrm{~mm}$, e fibras de carbono contínuas orientadas na direção transversal do corpo de prova.

As amostras do material multidirecional foram retiradas de um cilindro rompido, após ensaio hidrostático. As amostras foram retiradas do cilindro por meio de corte a laser, para preservação da superfície de fratura. O cilindro, fabricado pelo processo de bobinamento filamentar ("filament winding"), possuía espessura nominal de 1,2 mm.

A figura 5 mostra dois exemplos das amostras de compósitos utilizados neste trabalho. A primeira é do compósito unidirecional com as fibras dispostas perpendicularmente à direção da tensão aplicada, e a segunda do compósito multidirecional, extraída do cilindro. Pelas imagens é possível notar a diferença de superfície gerada e o grau de complexidade relacionado a cada uma delas. 


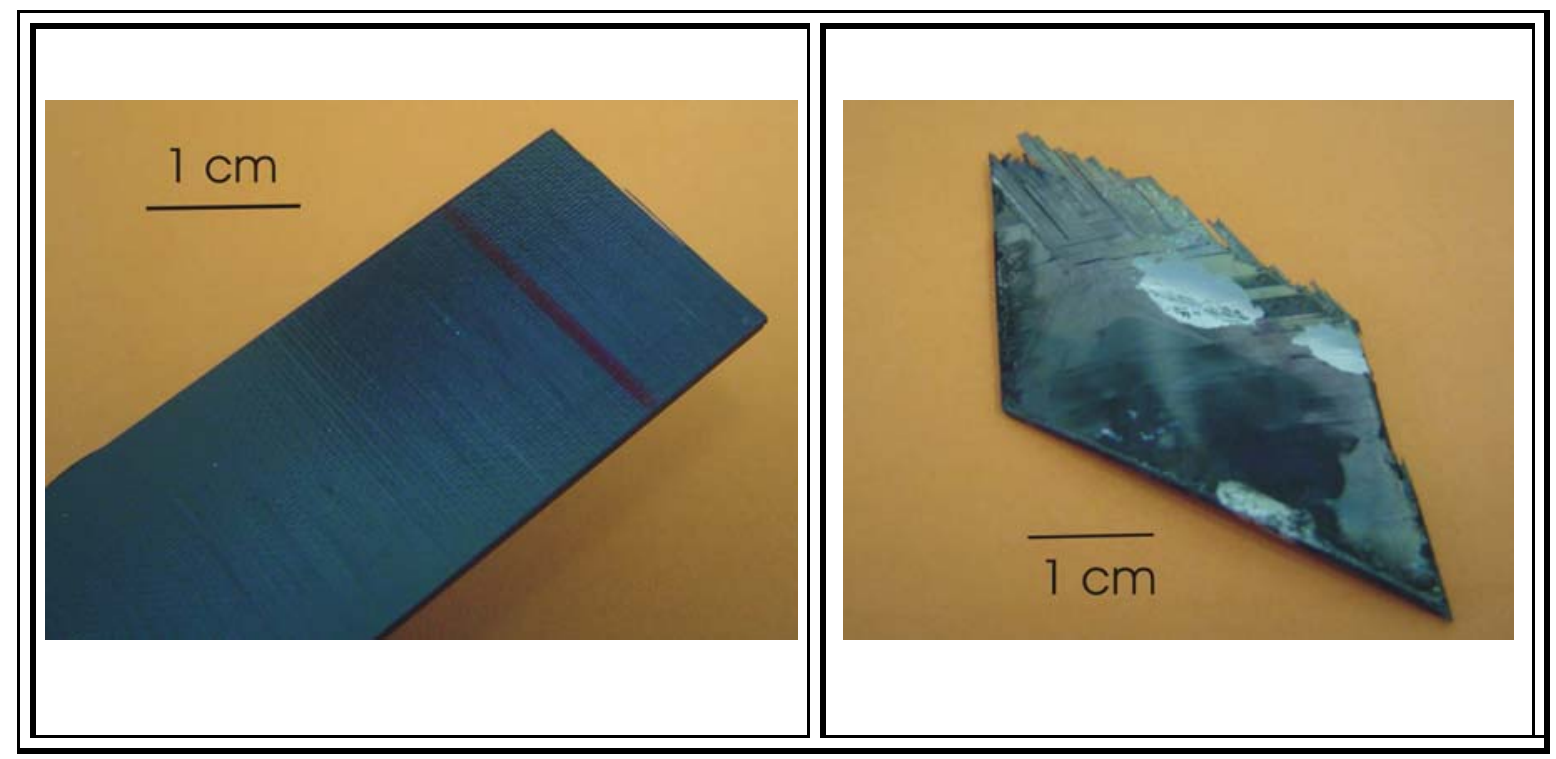

Figura 5: Amostras de material compósito unidirecional e multidirecional, utilizadas para a reconstrução $3 D$.

A utilização de materiais compósitos unidirecionais e multidirecionais, deve-se ao fato de que, após processo de fratura, as superfícies formadas apresentam morfologia com características diferentes. Enquanto o compósito com fibras unidirecionais apresenta uma superfície com pequena rugosidade, os compósitos multidirecionais se mostram com rugosidade bem acentuada e complexa em termos de detalhamento. A análise dessas superfícies corresponde a limites do processamento de imagens, em termos de complexidade, para verificação do método de reconstrução 3D.

O uso de amostras de outros tipos de materiais teve como objetivo a comparação de resultados e a exploração dos limites da técnica de reconstrução, visando a sua utilização da forma a mais abrangente possível, sem se deter às características apenas dos materiais compósitos. Sempre que preciso, a análise de uma superfície de fratura de outro material era reconstruída para verificar a aplicabilidade do método. 
O programa utilizado para a reconstrução tridimensional é o "ImageJ", um software de domínio público, voltado para o processamento de imagens, baseado em programa desenvolvido pelo Dr. Wayne Rasband do Ministério da Saúde dos Estados Unidos, que pode ser instalado em qualquer computador através do site http://rsb.info.nih.gov/ii.

O software desenvolvido em linguagem Java, possui características interessantes por ser uma linguagem voltada a objetos, que independe de plataforma, pois os programas em Java são compilados para uma forma intermediária de código denominada "bytecodes", que são como uma linguagem de máquina destinada a uma única plataforma, a máquina virtual Java JVM ("Java Virtual Machine"), que é um interpretador de bytecodes. Como é possível implementar uma JVM em qualquer plataforma, o programa Java pode ser executado em toda arquitetura que disponha de uma JVM.

A página principal do programa, mostrada na figura 6, é composta por ferramentas e menus, incluindo a possibilidade de adições através de "plugins", o que torna possível a resolução da maioria dos problemas envolvidos na análise ou processamento de imagens.

Em função dessa arquitetura aberta, o ImageJ permite extensibilidade através de plugins, em Java, que podem ser desenvolvidos utilizando o desenvolvedor no editor do ImageJ e um compilador Java. O usuário tem acesso ao programa fonte de qualquer uma de suas atualizações, o que é vantajoso para a discussão e análise dos resultados.

A rotina desenvolvida para a reconstrução tridimensional, como um plugin do ImageJ, foi fornecida pelo Prof. Rogerio Hein, da FEG/Guaratinguetá, e possui atualizações implementadas por E. Lucena ${ }^{(28)}$, em sua tese de doutorado. 


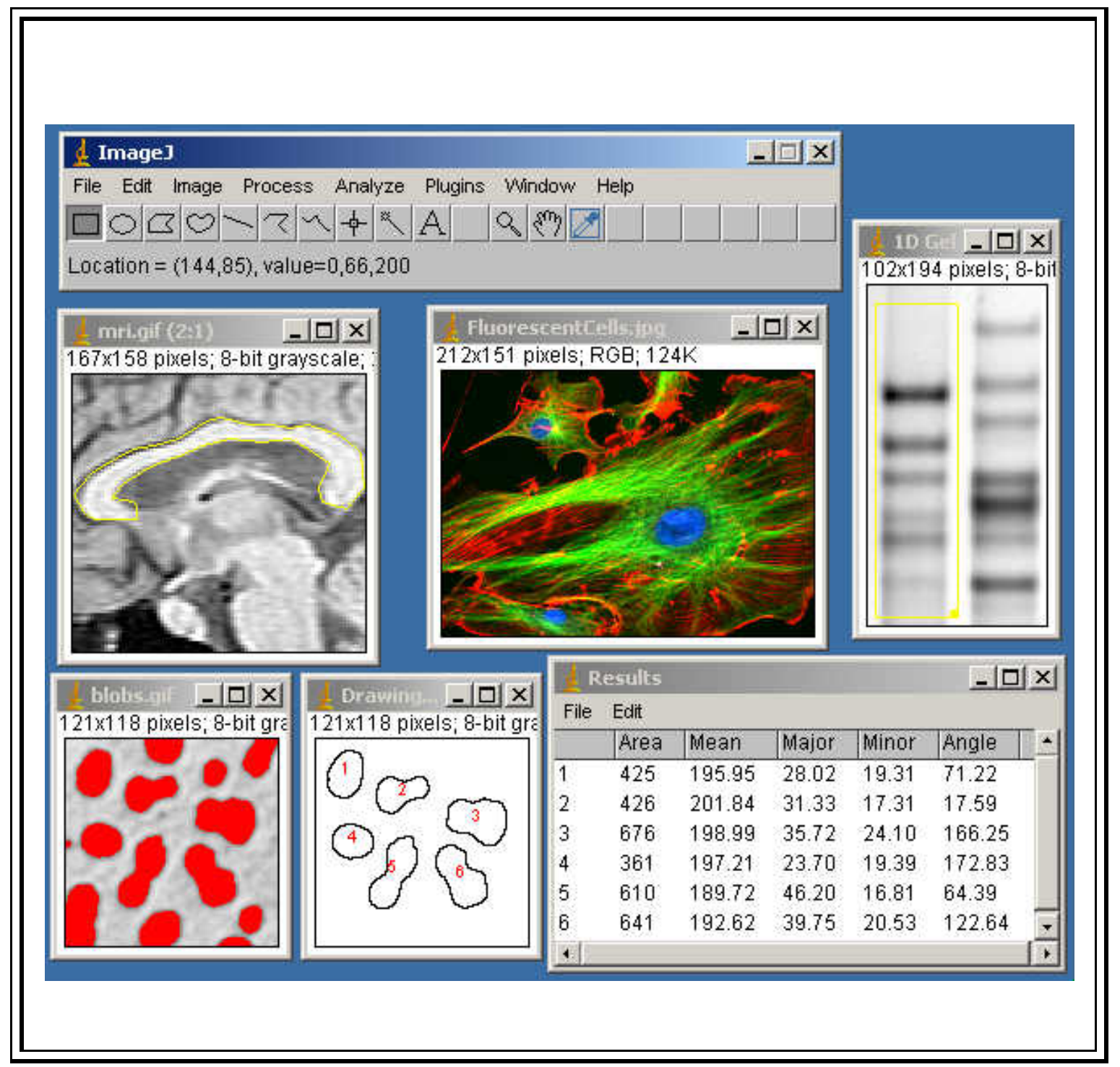

Figura 6: Página inicial do programa "ImageJ", com exemplos de resultados obtidos com suas ferramentas.

As micrografias utilizadas para a reconstrução tridimensional de superfícies foram obtidas utilizando microscopia óptica (MO) para a reconstrução a partir da variação de foco, e microscopia eletrônica de varredura (MEV), para a reconstrução a partir da paralaxe, por meio de um par estéreo de imagens. 


\subsection{Reconstrução por foco variável}

Imagens de uma mesma região são adquiridas digitalmente, em um microscópio óptico, em intervalos regulares de altura, com uma variação em torno da posição de foco, gerando uma pilha de imagens. Cada uma dessas imagens contém partes da região original que estão em foco para a altura considerada. O processamento dessa pilha de imagens produz um mapa de elevações e uma imagem reconstruída totalmente focalizada. Um esquema sobre a realização desse processo é apresentado na figura 7 .

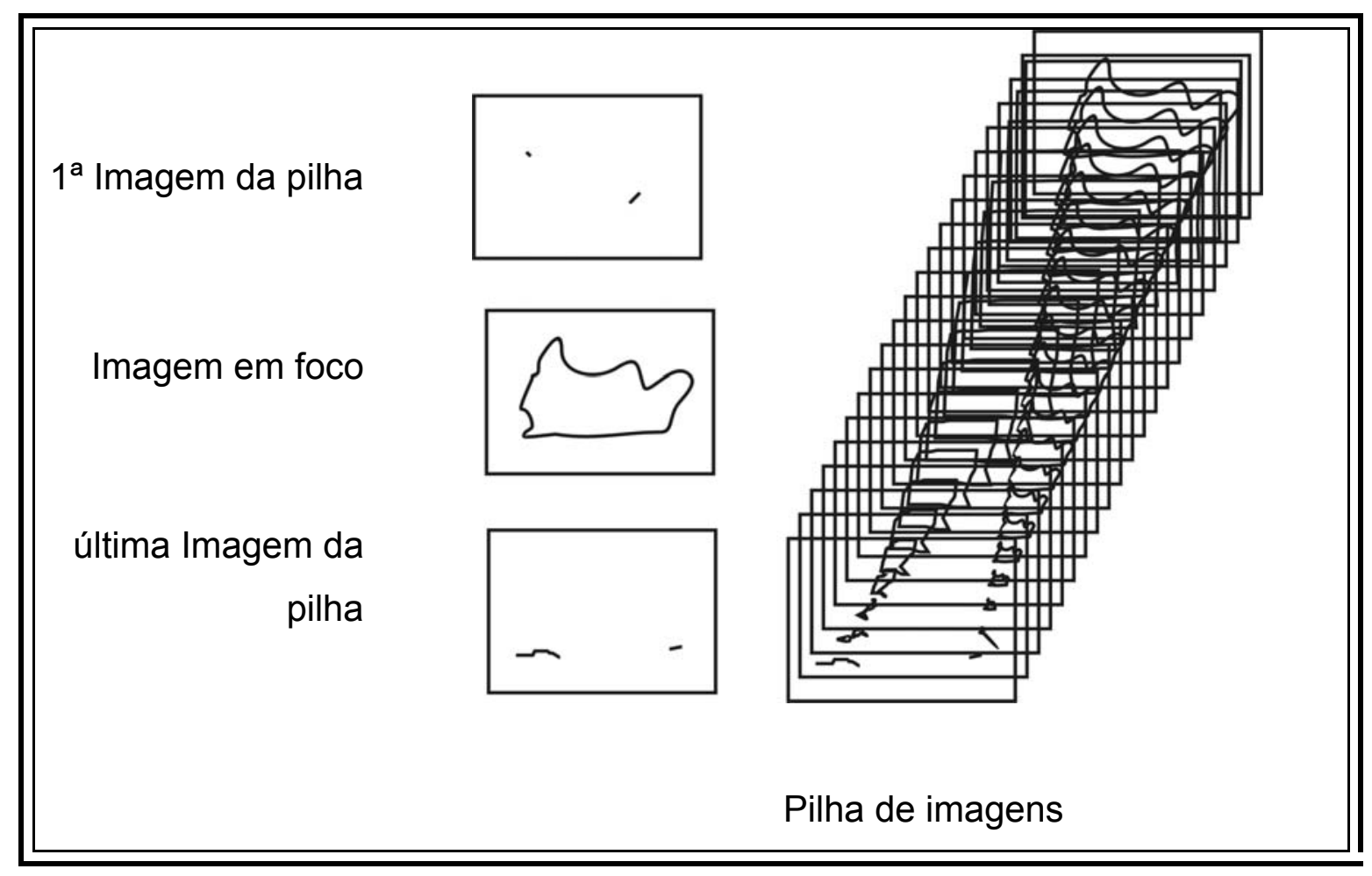

Figura 7: Esquema do processo de reconstrução a partir de uma pilha de imagens.

O método de reconstrução por foco variável, armazena micrografias a partir de uma primeira imagem, em posição inferior a do foco, até outra, em posição superior. Em cada uma delas, são registradas regiões com diferentes 
elevações, que estão em foco nessa altura, inferior ou superior, a do foco real. Dessa forma é possível realizar a reconstrução 3D, com todos os pontos em foco, independente da altura.

O processamento da pilha de imagens está baseado no critério de foco, que é calculado a partir da aplicação de uma matriz sobre a imagem, que calcula para cada pixel um índice de foco. Através desse valor é possível identificar em qual imagem da pilha, um determinado pixel está em foco. A imagem reconstruída será composta pelo valor de cada pixel em foco.

\subsection{Reconstrução por paralaxe}

As micrografias MEV são obtidas aos pares de uma mesma região da superfície, inclinando-se a amostra nos sentidos, horário e anti-horário, com relação à posição horizontal. As diferenças entre as projeções dessas imagens é que permite o cálculo da elevação.

Para simplificar os cálculos, foi adotado o mesmo ângulo de inclinação para os dois sentidos. A localização das elevações a serem calculadas em cada imagem é obtida pelo programa ImageJ, que procura regiões correspondentes nas duas micrografias do par estéreo. A determinação da elevação é dada pela expressão apresentada no esquema da figura 8.

O cálculo da elevação local depende da paralaxe e o valor para o $\Delta \theta$ não deve ser tão pequeno, que possam ser influenciados pelos erros durante o posicionamento da inclinação, e nem tão grandes que venham a sobrepor e ocultar características da imagem.

A etapa mais importante do processo é a determinação das posições semelhantes nas duas imagens, pois a diferença entre as projeções da primeira e da segunda imagem é que vai determinar a elevação ponto a ponto 
no mapa de elevações produzido. A precisão com que se busca o casamento entre as imagens é determinante para a qualidade da reconstrução.

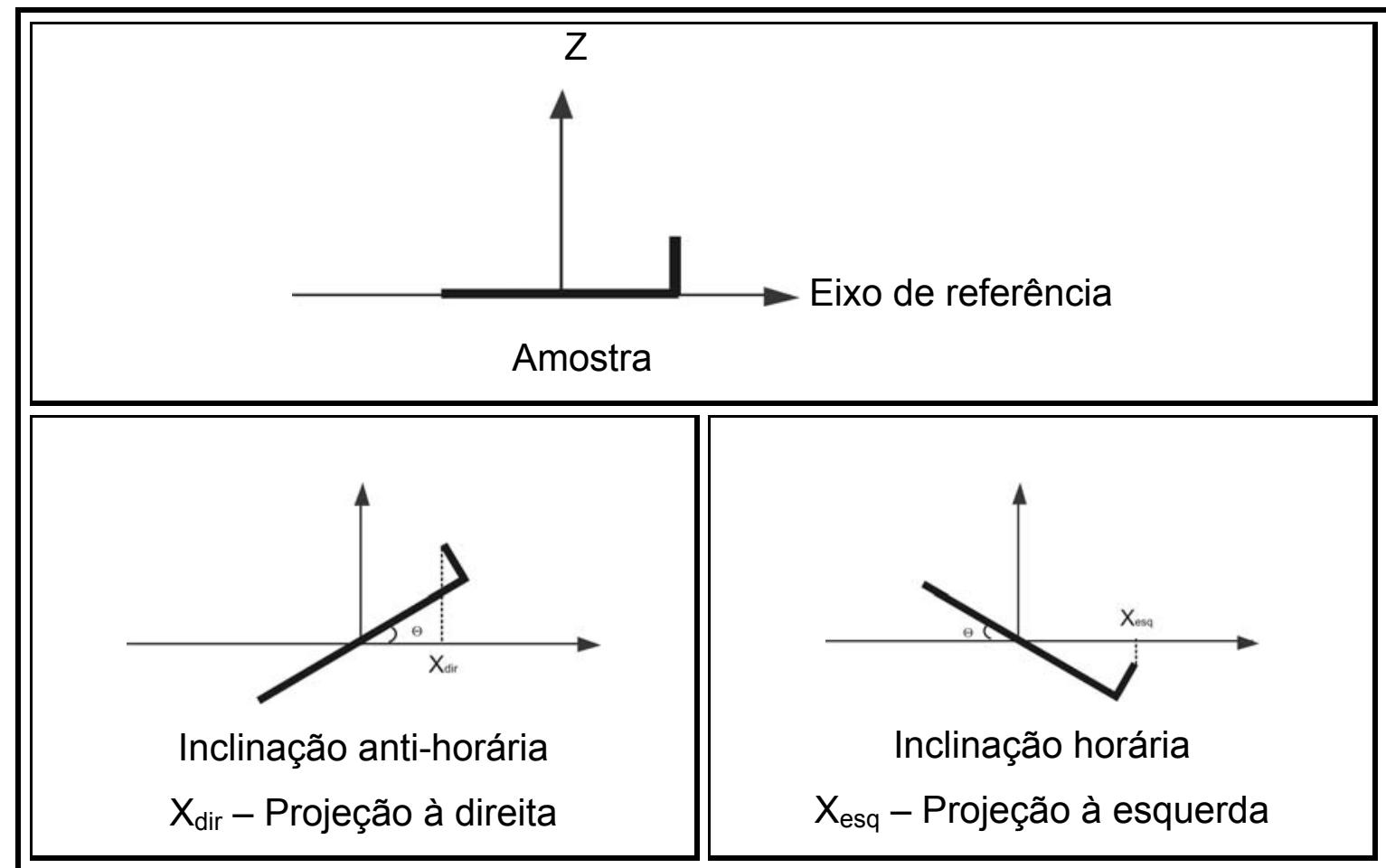

Cálculo da elevação (Z), para inclinações de mesmo ângulo:

$$
Z=\frac{1}{M}\left(\frac{X e s q-X d i r}{2 \operatorname{sen}(\Delta \Theta / 2)}\right)
$$

Onde:

$Z$ = elevação

$\mathrm{M}=$ aumento da imagem MEV

$\theta=$ ângulo de inclinação da amostra

Figura 8: Esquema do processo de reconstrução 3D, através de par estéreo. 
Segundo Lucena ${ }^{(28)}$, o tempo de processamento para buscar a região semelhante é uma característica desfavorável do processamento. Para tentar minimiza-lo, alguns programadores usam limitadores ("constraints") com o objetivo de diminuir o espaço de busca. Dentre eles estão o unívoco, similaridade, seqüencial e o de continuidade: o primeiro diz que o resultado deve ter valor único máximo ou mínimo e o segundo que a região deve ser a mais semelhante possível. O limitador seqüencial diz que se uma região $A$ tem uma semelhante $B$, em outra imagem, não se pode encontrar uma região $C$, tal que $X_{C}<X_{A}$, que possua uma região semelhante $D$ para $X_{D}>X_{B}$. O limitador continuidade afirma que pontos vizinhos possuem paralaxes com valores próximos. Um outro limitador bastante usado para obter superfícies a partir de imagens MEV é o epipolar, que faz com que a busca seja feita em uma única direção.

A manipulação das imagens utilizadas no programa de reconstrução, utiliza a transformada de Hartley, em vez da transformada de Fourier, pelo fato de ser definida no campo dos números reais, o que possibilita a redução do tempo de processamento, pois a lógica matemática é mais facilmente programada nesse campo.

O casamento entre as imagens do par estéreo é realizado a partir da distribuição de brilhos, que produz um mapa denso de elevações, onde o cálculo de altura pode ser realizado para cada pixel individualmente, sem a necessidade de interpolação. 


\section{Resultados \& Discussão}

A seguir, são apresentadas algumas imagens de superfície de fratura de materiais compósitos multidirecionais, reforçados com fibras contínuas de carbono, obtidas por microscopia eletrônica de varredura (MEV), com a finalidade de mostrar a riqueza de detalhes característica desse material e a dificuldade para analisar a rugosidade dessas superfícies.

As micrografias apresentam vários modos de fratura com variações em termos de ampliação das imagens e de tensão de aceleração que ilustram os cuidados que devem ser tomados durante a aquisição das mesmas, independentemente do equipamento utilizado.

O arrancamento, a quebra de fibras e danos na matriz polimérica são mostradas nas figuras 9 e 10, com imagens adquiridas em um MEV, da marca Philips, modelo XL-30. Na figura 9, esses modos de fratura são apresentados com diferentes aumentos e tensões. $\mathrm{Na}$ imagem superior foi utilizada uma tensão de $20 \mathrm{kV}$ e um aumento de 200 vezes, e na imagem inferior a tensão de aceleração é de $10 \mathrm{kV}$ com um aumento de 500 vezes.

A figura 10 mostra a mesma região com um aumento de 500 vezes, mas com tensão de aceleração de 5kV. Essa tensão é considerada a mais apropriada para a realização da reconstrução tridimensional, pois produz uma imagem quase sem excesso de brilho.

O excesso de brilho, que deve ser evitado, pode acarretar em uma perda de informação localizada, que interfere na definição de detalhes da superfície, o que dificulta o casamento entre as regiões das imagens inclinadas, na hora do alinhamento. A qualidade da imagem está relacionada com a qualidade da informação contida e não com sua percepção visual, que pode ou não ser agradável, como no conceito de beleza. 

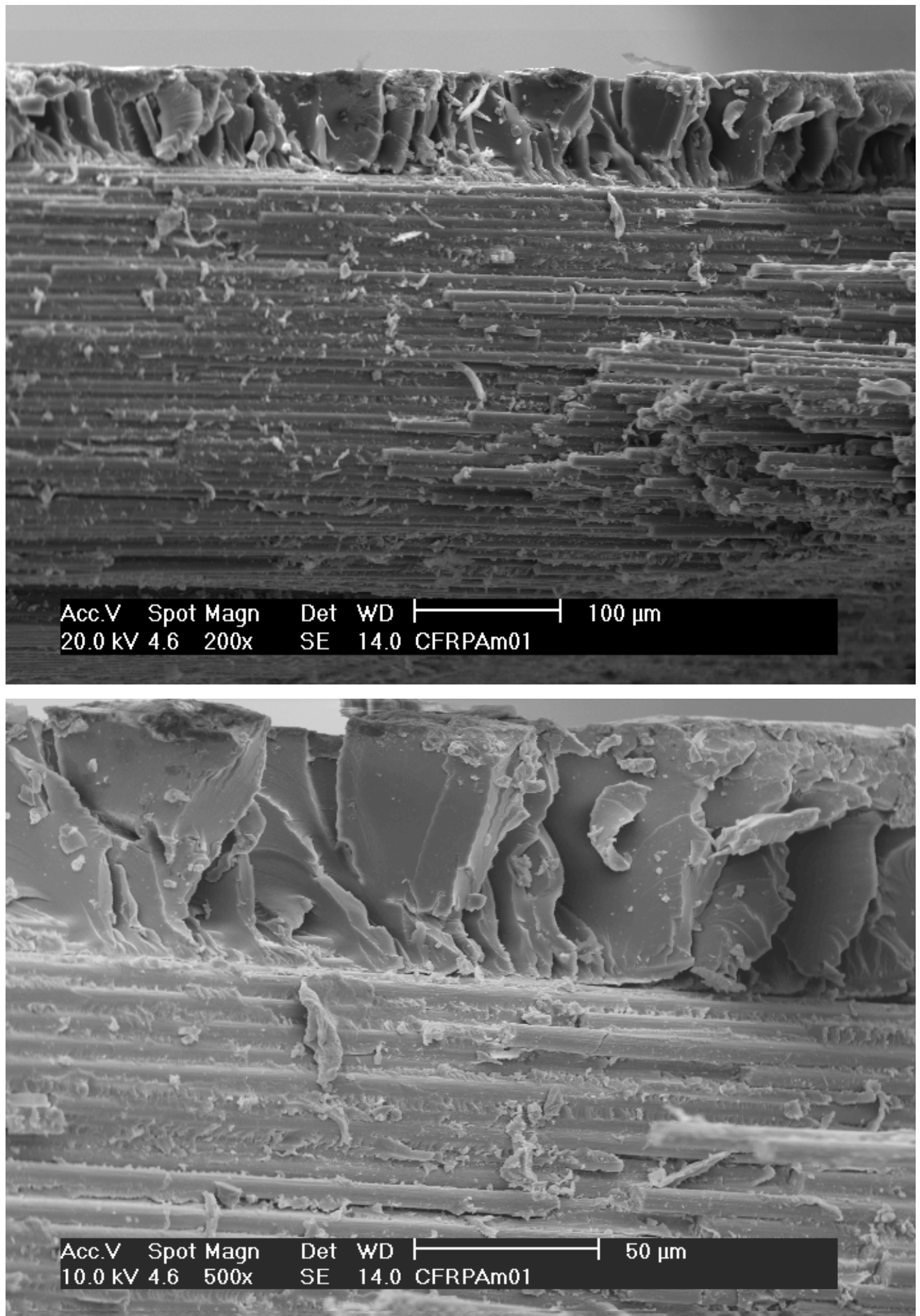

Figura 9: Imagens de superfície de fratura de material compósito obtidas com diferentes tensões, com MEV XL-30, Philips. 

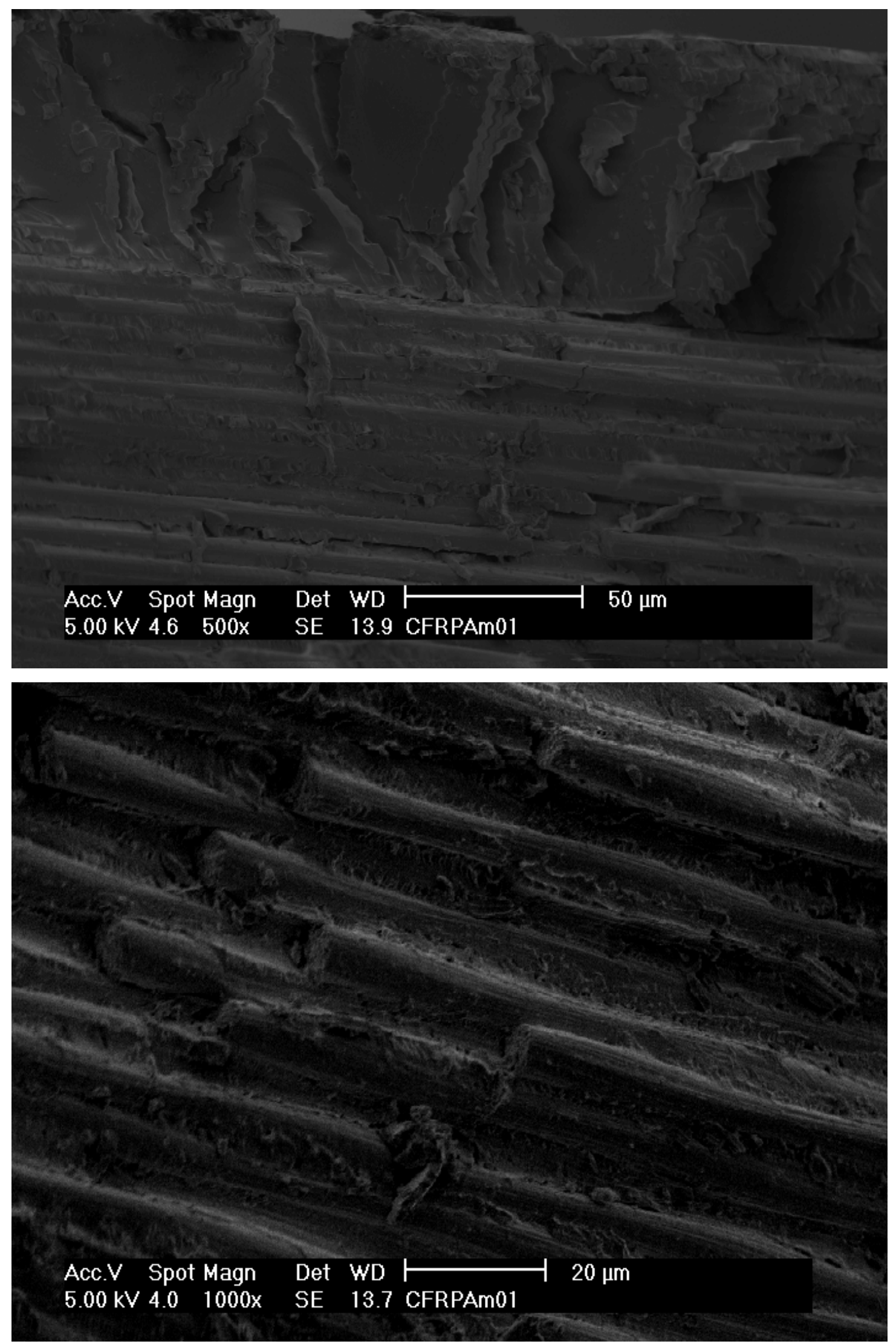

Figura 10: Imagens de superfícies de fratura de material compósito, obtidas em MEV XL-30, Philips, com $5 \mathrm{kV}$. 
Na figura 11 é possível observar a delaminação, o arrancamento, a quebra de fibras e alguns aspectos característicos de danos na matriz polimérica, como as marcas deixadas por fibras após o descolamento entre fibra e matriz.

As imagens da figura 12 foram adquiridas por um MEV, da marca Camscan modelo S4, com um detector de elétrons retroespalhados. Em todas as três imagens, foi utilizada uma tensão de aceleração de $20 \mathrm{kV}$, mas os aumentos foram de 36x, 110x e 140x, respectivamente. É interessante ressaltar que as imagens obtidas com esse detector, possuem um baixo contraste e, somente podem ser vistas depois de serem abertas e armazenadas no programa ImageJ.

Uma superfície típica de arrancamento, com a exposição de parte das fibras é apresentada na figura 13, adquiridas com o mesmo microscópio com tensão de aceleração de $20 \mathrm{kV}$, com detector de elétrons retroespalhados e aumento de 500x e, detector de elétrons secundários com aumento de 1560x.

A figura 14 mostra regiões com delaminação, arrancamento e quebra de fibras em uma amostra de superfície de compósito CFRP, adquiridas com um microscópio MEV, da marca Hitachi, modelo TM 1000 e detectores de elétrons retroespalhados, com aumentos de 1000x e 4000x.

As imagens apresentadas mostram um pouco da complexidade das superfícies de fratura de materiais compósitos multidirecionais, de matriz epóxi, reforçada com fibras contínuas de carbono. A grande diversidade de detalhes pode ser avaliada através de uma grande variação da ampliação das imagens. Alguns aspectos como delaminação podem ser avaliados por microscopia óptica, enquanto outros são melhores avaliados por microscopia eletrônica de varredura, como o caso de detalhes do arrancamento de fibras. 

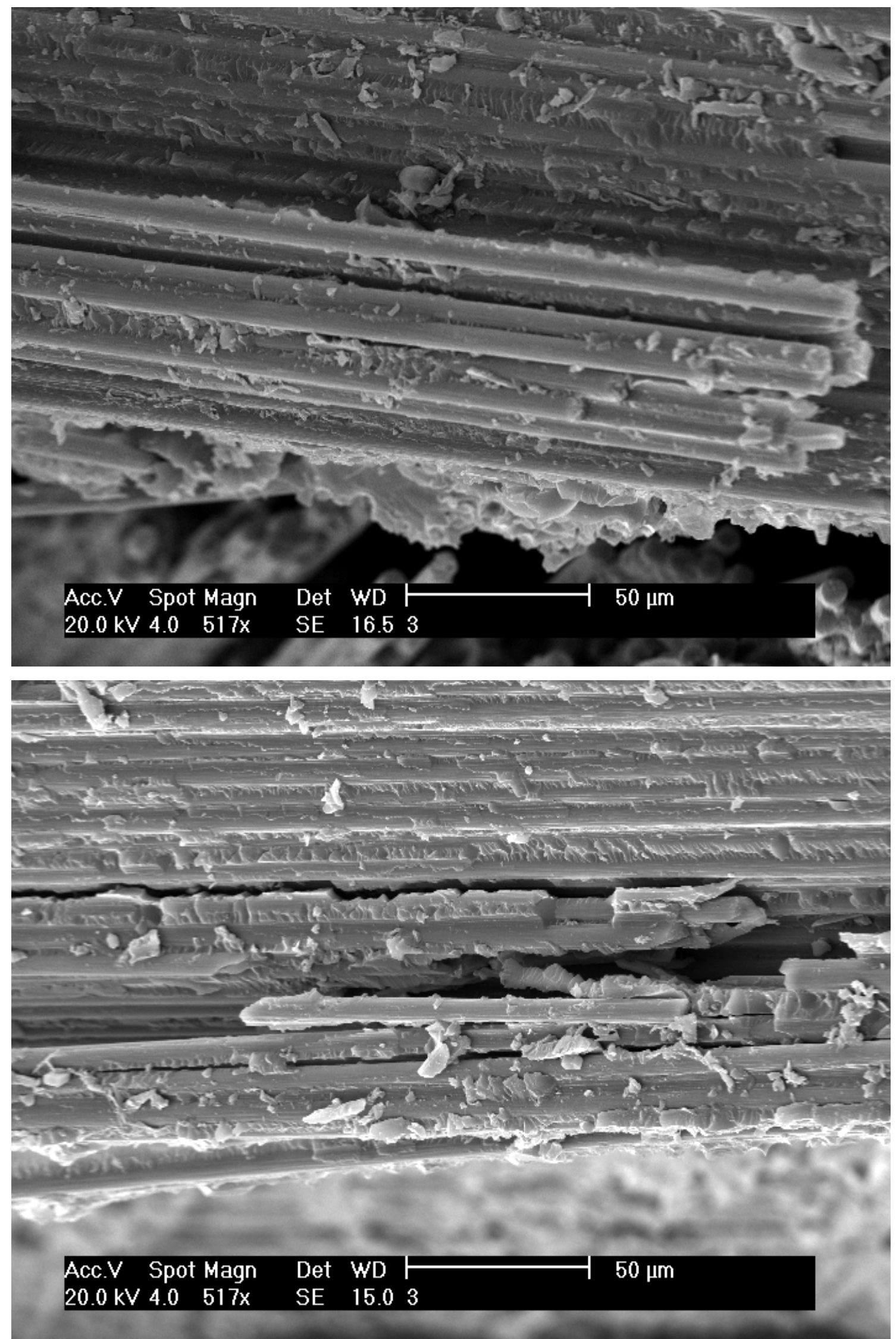

Figura 11: Superfícies de fratura de materiais compósitos contendo delaminação e arrancamento de fibras. 

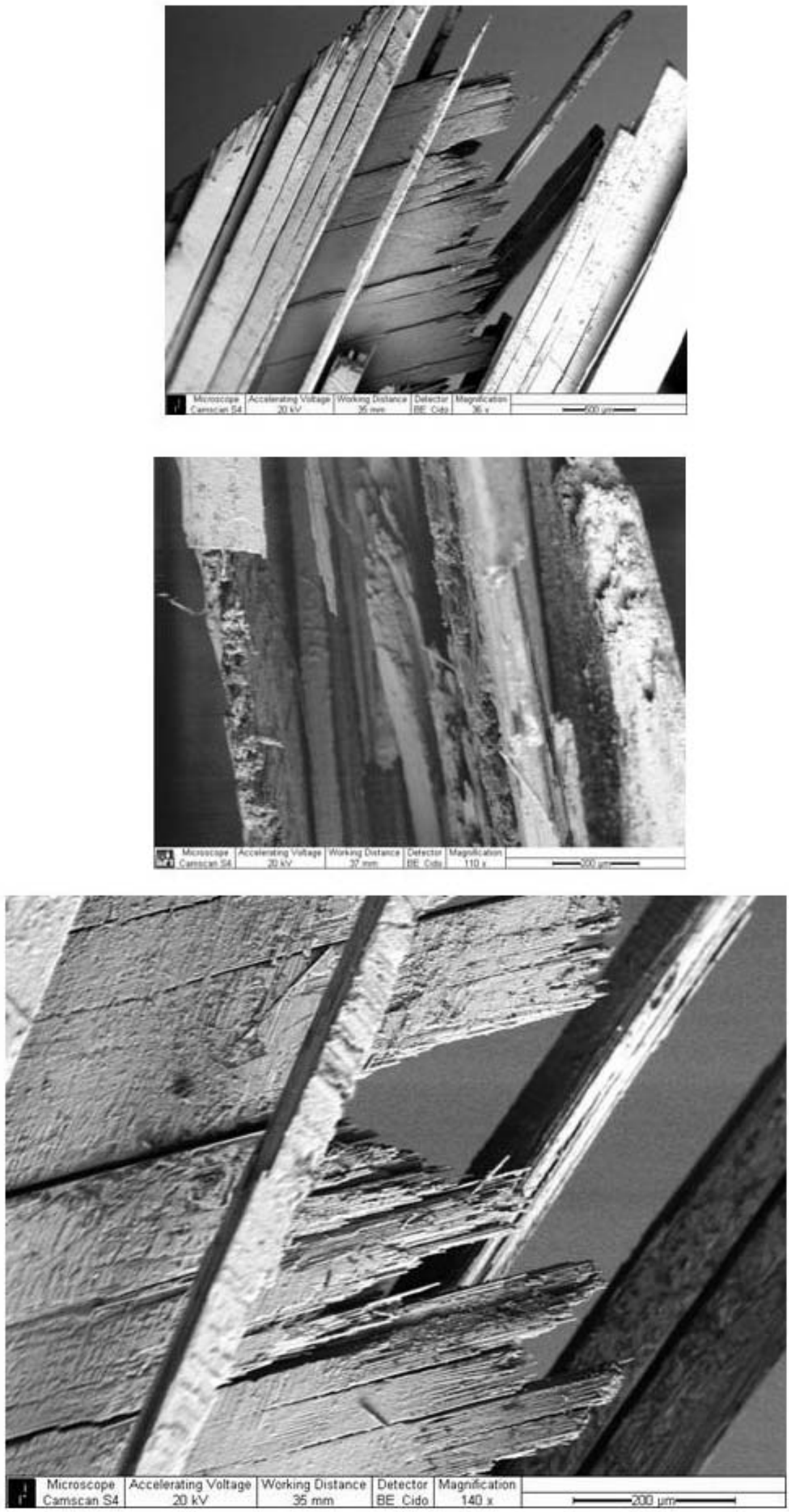

Figura 12: Superfícies de fratura de materiais compósitos, obtidas com detector de elétrons retroespalhados. 

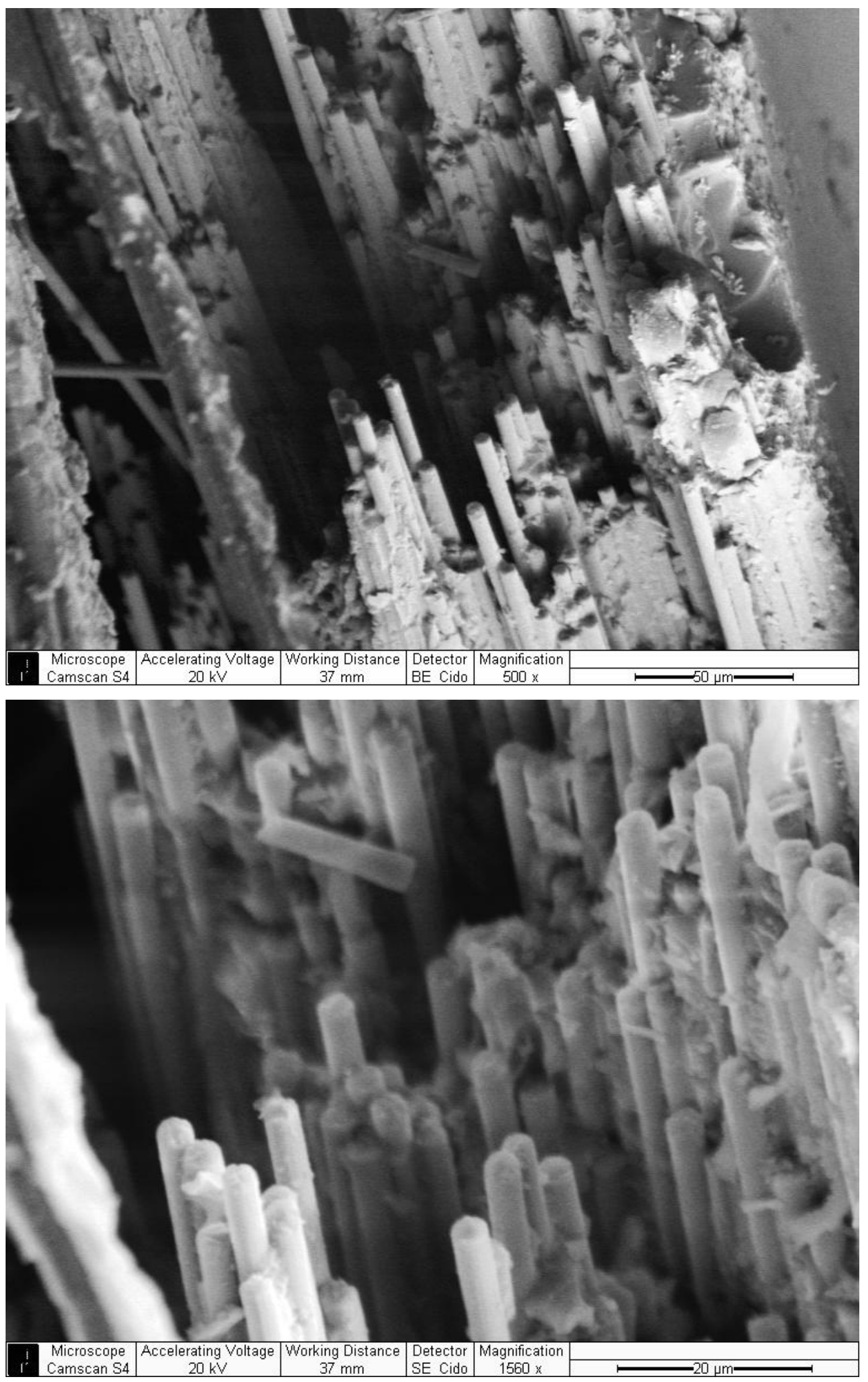

Figura 13: Superfícies de fratura de materiais compósitos, obtidas com MEV Camscan S4 e tensão de aceleração de $20 \mathrm{kV}$. 

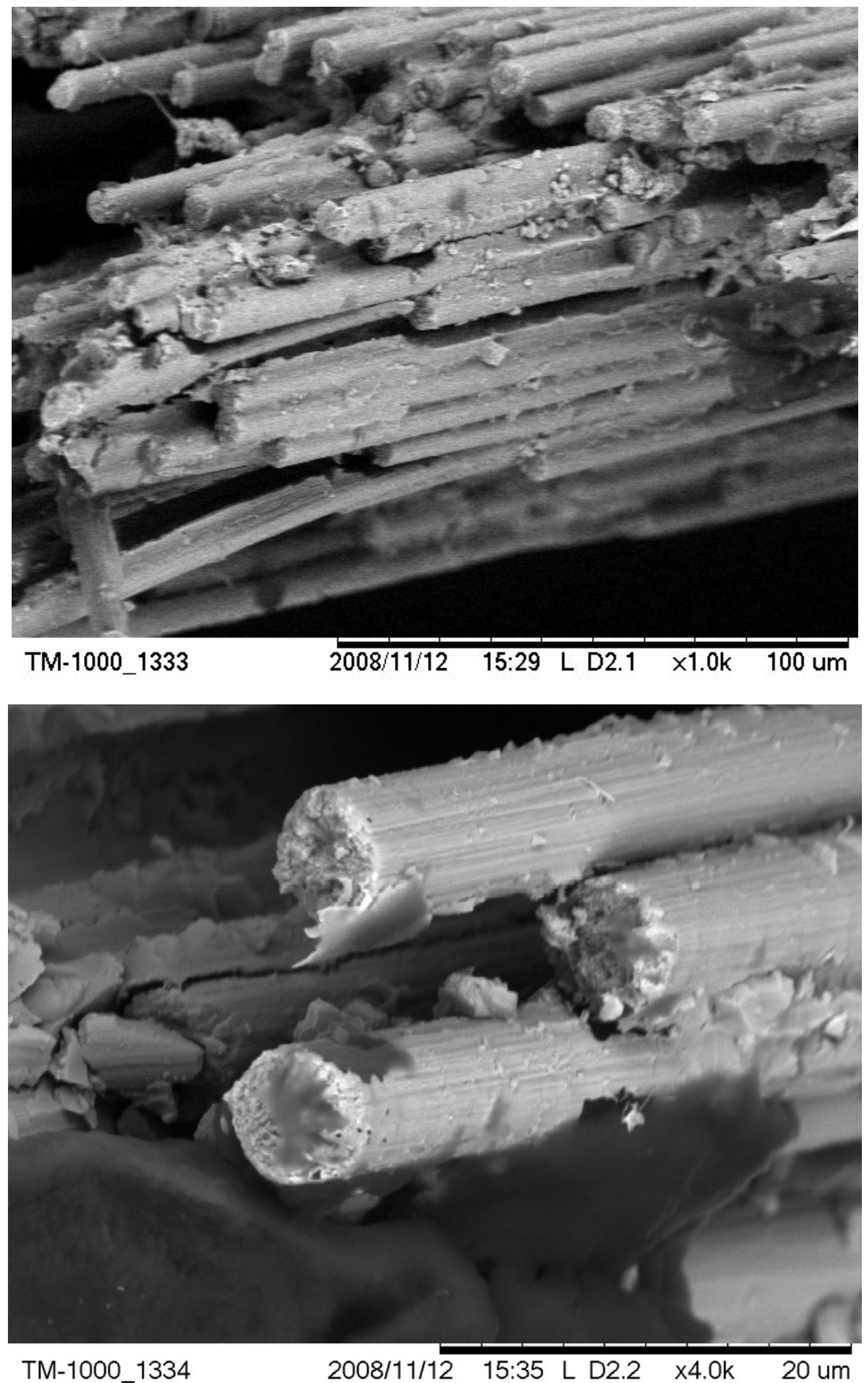

Figura 14: Superfícies de fratura de materiais compósitos, obtidas em MEV Hitachi, TM 1000. 
A caracterização de superfícies de fratura foi realizada em uma faixa de magnificação que abrange os baixos valores da microscopia óptica até as ampliações possíveis com a microscopia eletrônica de varredura. A finalidade é analisar os detalhes da superfície através de fractografias da região de interesse. As primeiras análises foram realizadas com a reconstrução da superfície de fratura pelo método do foco variável, com micrografias ópticas.

Os resultados para uma amostra de compósito CFRP unidirecional são mostrados na figura 15, onde é possível observar a imagem reconstruída e o mapa de elevações produzido durante o processamento da pilha de imagens. O processamento e a aquisição das imagens foram realizados no Laboratório de Análise de Imagens de Materiais - LAIMat, FEG - Guaratinguetá.

A imagem reconstruída mostra uma superfície do corpo de prova resultante do teste de tração, com as fibras distribuídas na direção transversal desse corpo de prova. Nesse tipo de ensaio, as fibras são facilmente removidas da superfície, pois não oferecerem nenhuma resistência à tração aplicada em sentido perpendicular ao seu comprimento.

Na superfície observada, com sua rugosidade bem definida, onde todos os pontos se encontram perfeitamente em foco, é possível verificar regiões características de falhas que apresentam ausências de fibras. Estas são melhor visualizadas com o auxílio do mapa de elevações que pode ser gerado, e é mostrado na parte inferior da figura, cuja visualização da variação em altura da superfície, favorece a análise de rugosidade.

Outras imagens reconstruídas, do mesmo material CFRP são apresentadas nas figuras 16 e 17, e reafirmam a boa qualidade da imagem obtida e com detalhamento superficial correspondendo ao grau de aumento da imagem disponível em um microscópio óptico. $\mathrm{Na}$ figura 16 é possível observar detalhes da lateral de uma das amostras, e a figura 17 mostra detalhes do arrancamento das fibras e de delaminação. 


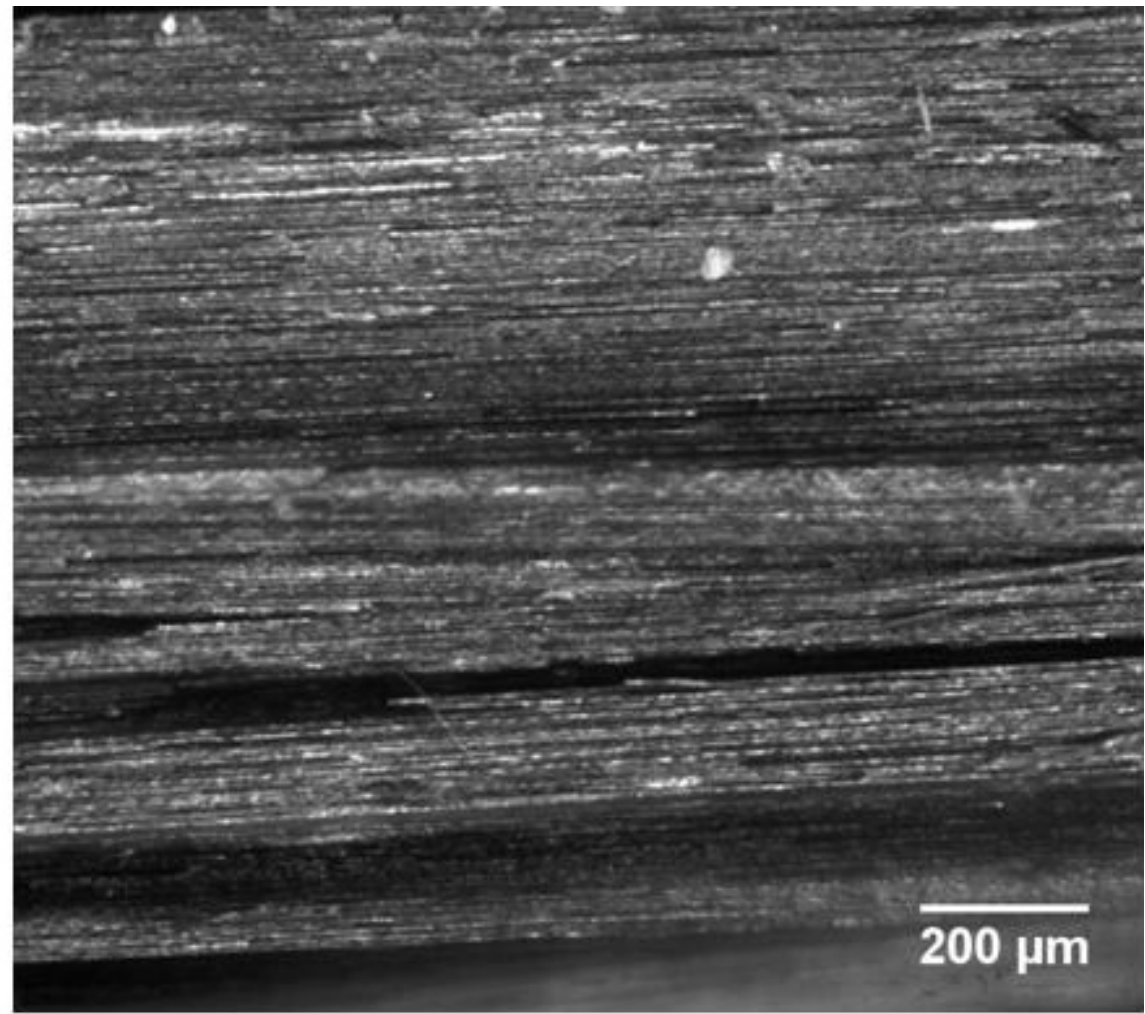

(a)

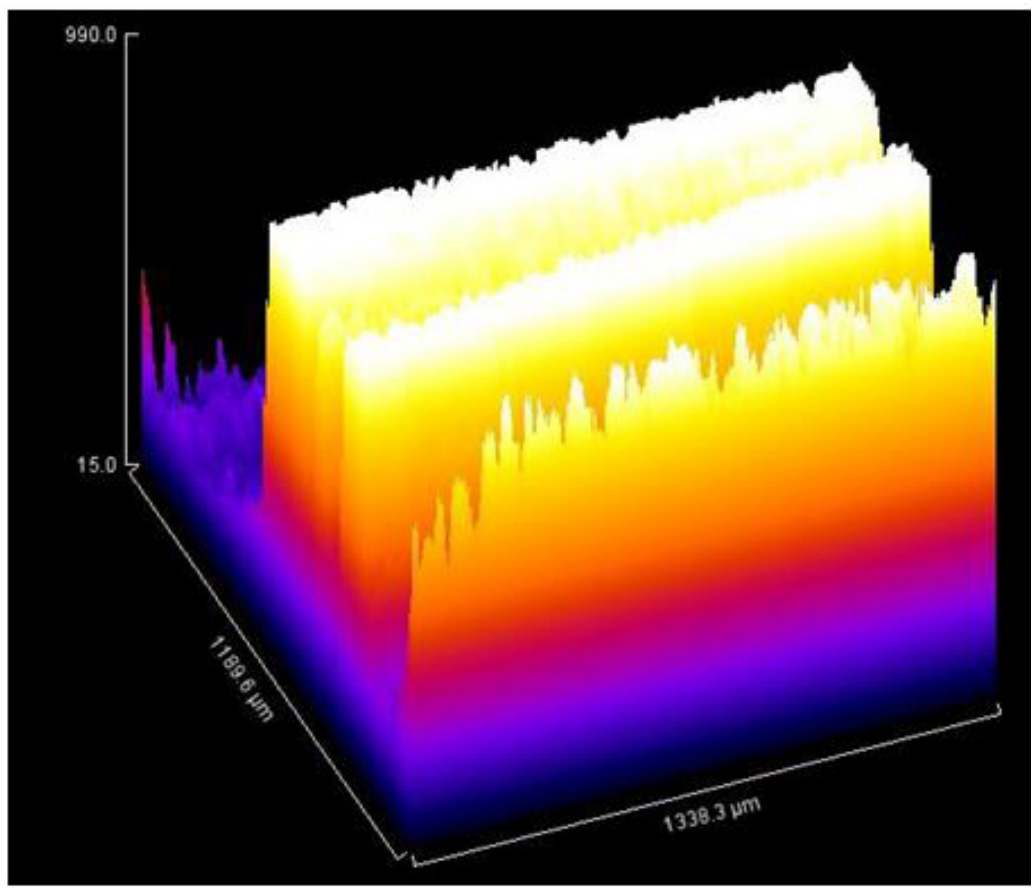

(b)

Figura 15: (a) Imagem reconstruída de superfície de fratura de compósito unidirecional e (b) mapa de elevações, obtidos pelo método de variação de foco. 

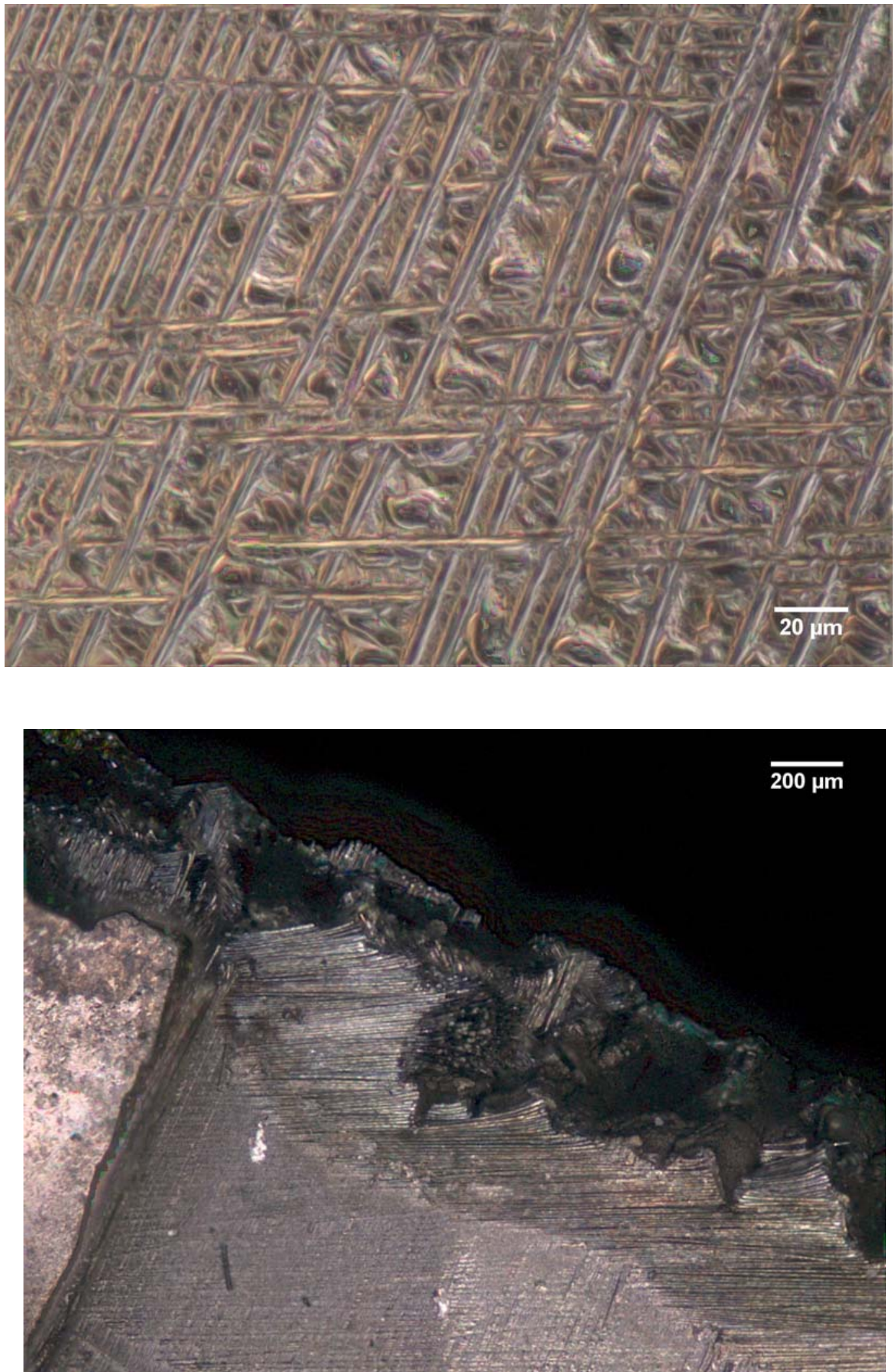

Figura 16: Imagens reconstruídas de superfície de fratura de compósito unidirecional obtidas pelo método de variação de foco. 

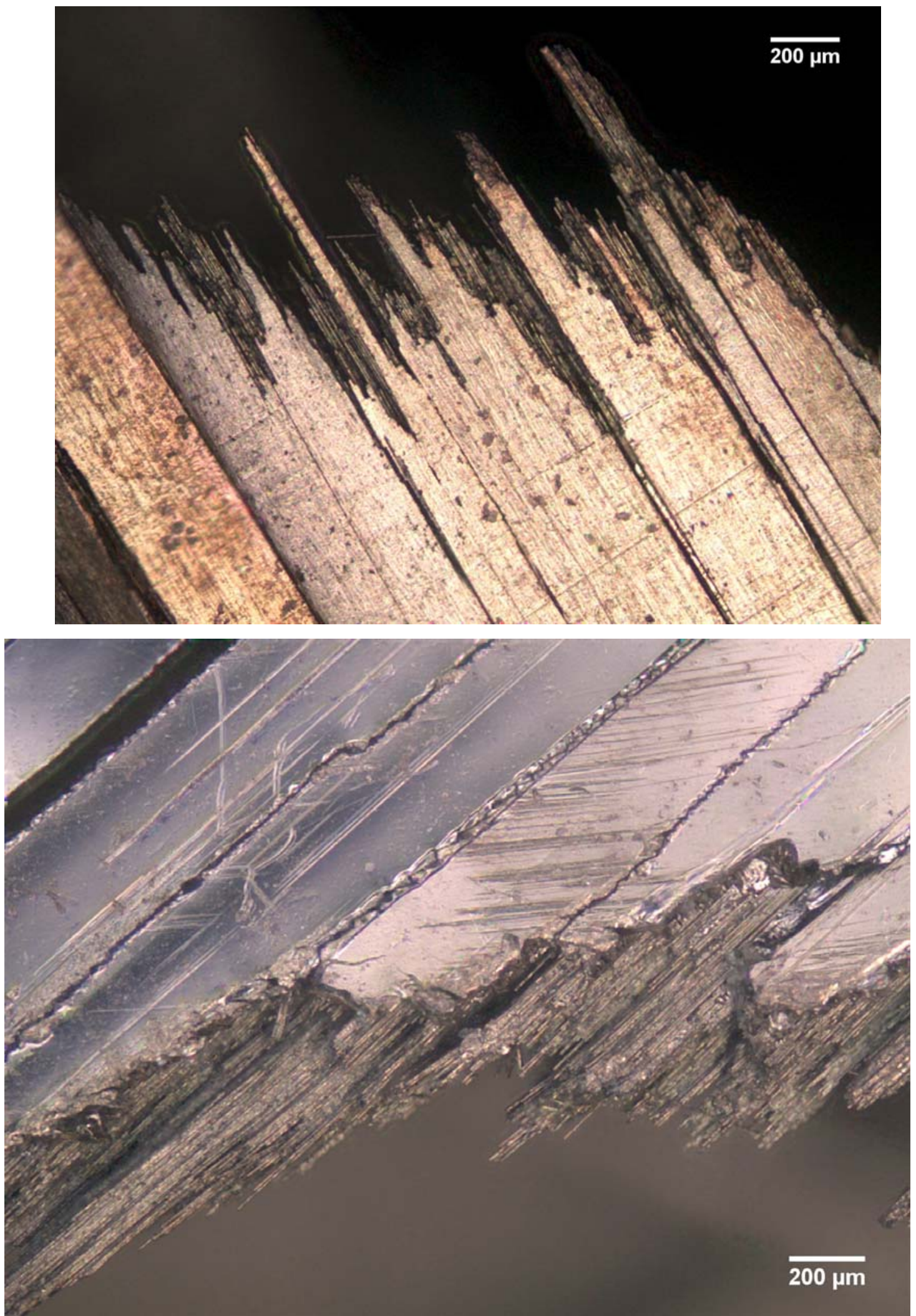

Figura 17: Imagens reconstruídas de superfície de fratura de compósito unidirecional obtidas pelo método de variação de foco. 
Os resultados obtidos com o método de reconstrução por foco variável confirmam a eficácia do método para a reconstrução de superfícies de fratura. A imagem reconstruída e o mapa de elevações mostram uma perfeita reconstrução da região, com alto grau de detalhamentos, que possibilitam a visualização total da superfície.

Dentro dos limites da microscopia óptica, esses resultados podem ser classificados como de excelente qualidade. Entretanto, alguns aspectos práticos devem ser levados em consideração durante a escolha do melhor método para a reconstrução.

O tempo necessário para aquisição da pilha de imagens é relativamente alto, pois o número de imagens necessárias para um bom resultado é elevado e depende do intervalo estabelecido em torno da posição de foco que se deseja variar. Supondo que sejam necessárias 100 imagens, deve-se pensar que 100 arquivos serão gerados durante o processo. Se a aquisição for realizada de maneira automática, com microscópio óptico dotado de estágio motorizado e que permita ser programado, essa dificuldade desaparece e a qualidade do resultado compensa todo esforço realizado. Esse procedimento requer um elevado tempo de dedicação do instrumento, além da manutenção das mesmas condições de imagem durante todo o processo.

A opção por este método deve ponderar esses fatores e ter em mente qual a escala de detalhamento que se deseja observar através da reconstrução. Os resultados são excelentes dentro das limitações do equipamento utilizado para a aquisição das imagens.

As imagens reconstruídas por variação de foco, propiciam uma boa análise das superfícies de fratura para os compósitos CFRP, mas o baixo aumento não permite a obtenção de parâmetros importantes para o estudo dos modos de fratura, sendo necessário à utilização de outro método para reconstrução: o método da paralaxe, através de um par estéreo de imagens MEV. 
Os primeiros resultados da reconstrução por paralaxe são apresentados na figura 18, que contém o par estéreo de imagens utilizado e o mapa de elevações gerado durante o processamento. As imagens foram obtidas com uma inclinação de $\pm 2^{\circ}$ em relação à posição horizontal.

A reconstrução por paralaxe realizada com imagens de um compósito CFRP multidirecional, a princípio não apresentou um resultado satisfatório, principalmente com relação a imagem reconstruída, o que levou a identificação de aspectos críticos e da necessidade de procurar estabelecer, inicialmente, um método padrão para a aquisição de imagens do par estéreo, levando em conta as características do equipamento utilizado.

Diferentes microscópios eletrônicos de varredura foram utilizados para aquisição de imagens durante todo o trabalho, mas a maior parte delas foi obtida por um MEV, marca Philips, modelo XL30. Algumas comparações entre as marcas e modelos podem ser feitas com relação a tamanho da câmara, qualidade de imagens e diversos acessórios, mas de uma forma geral, o posicionamento do feixe e dos detectores assume um padrão entre eles.

No processo de obtenção das imagens do par estéreo, a maior preocupação foi quanto ao deslocamento da região de interesse durante a inclinação da amostra. Quanto maior o ângulo de inclinação, maiores eram os deslocamentos no plano $\mathrm{x}, \mathrm{y}$ necessários para recuperar a região original, onde se marcava o posicionamento de alguma característica, como referência do posicionamento. Esse deslocamento é influenciado pelo aumento utilizado durante a aquisição das imagens, e quanto maior for esse aumento, maior será o deslocamento da região de interesse, com pequenas alterações no posicionamento. Com esse procedimento meramente visual, muitos deslocamentos eram introduzidos nas imagens, acarretando em uma dificuldade maior no casamento das regiões, que é o passo fundamental para uma boa reconstrução. 


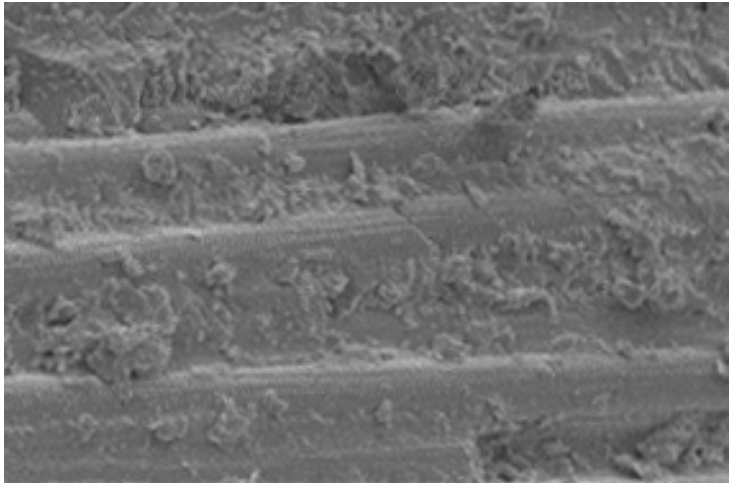

$+2^{\circ}$

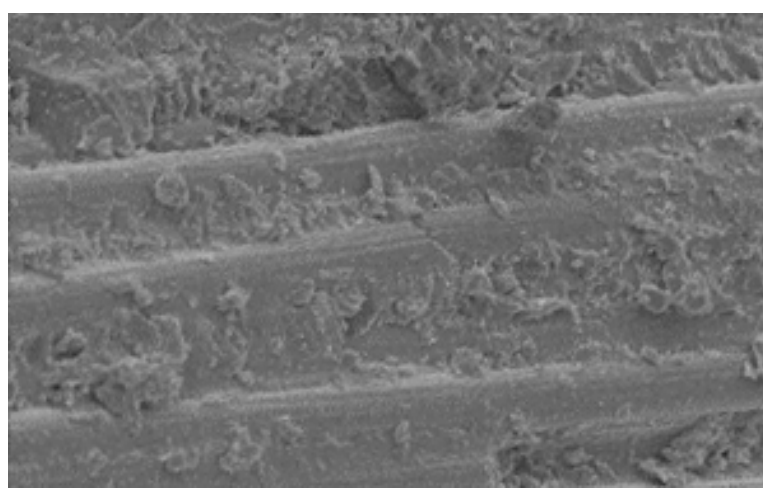

$-2^{\circ}$

(a)

(b)
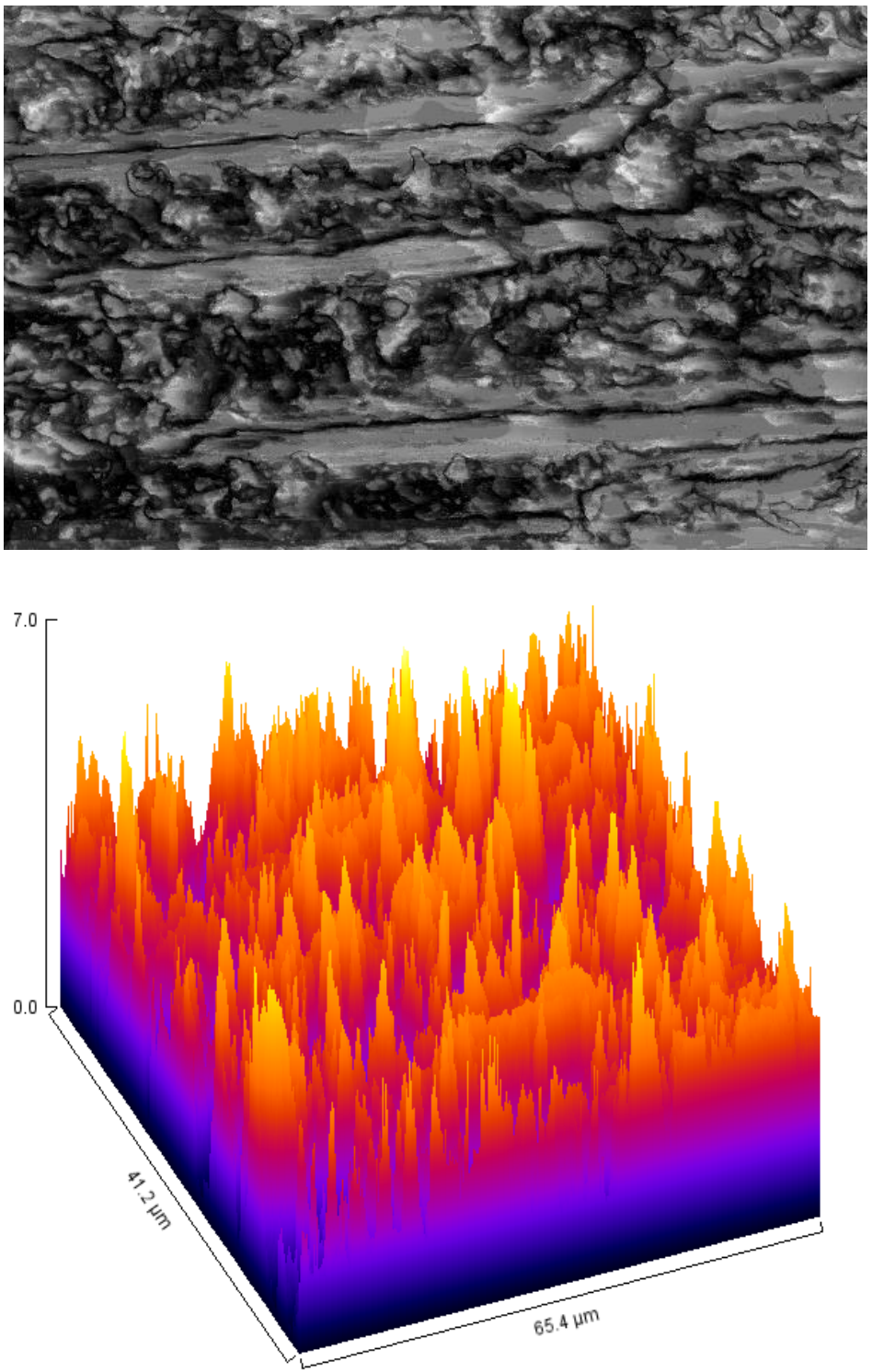

Figura 18: Reconstrução de superfície de fratura de compósito obtida pelo método da paralaxe: (a) par estéreo;(b) mapa de elevações. 
As características do equipamento utilizado para a aquisição das imagens determinam os procedimentos corretos para evitar a ocorrência desses deslocamentos. Uma representação esquemática na figura 19 apresenta as características da câmera do MEV XL30, com o posicionamento do detector de elétrons secundários e o porta-amostra, mostrando as variações que ocorrem com a inclinação da amostra nos sentidos horário e anti-horário.

O porta-amostra deste modelo de MEV está fixo na parede interna da porta da câmera e realiza o mesmo movimento que o mecanismo que inclina a amostra e marca o valor do ângulo de inclinação. Por estar fixo em uma posição periférica, ele realiza um movimento circular durante a inclinação, saindo do eixo central de incidência do feixe eletrônico. A imagem da região de interesse é recuperada somente com o reposicionamento da amostra, através dos mecanismos de deslocamento no plano $\mathrm{XY}$.

Alguns equipamentos possuem o posicionamento eucêntrico do porta-amostra, que é fixado em uma posição central, no centro da câmera. Ao ser inclinado, o porta-amostra mantém o eixo central fixo e dessa forma preserva o posicionamento da região a ser observada. A desvantagem de um porta-amostra eucêntrico é limitar a altura da amostra a ser observada em quase $50 \%$ da altura permitida para um porta-amostra fixo na parte inferior. $O$ interessante é que existe a possibilidade de calibrar o posicionamento eucêntrico, mesmo para $\circ \mathrm{XL}-30$, através de procedimentos específicos fornecidos pelo fabricante. As instruções para esse procedimento são apresentadas no apêndice $B$.

O primeiro cuidado, portanto, é reconhecer o mecanismo de inclinação do porta-amostra ao se desejar adquirir um par estereo para reconstrução. Se o equipamento possuir porta-amostra eucêntrico, as imagens podem ser adquiridas de forma mais direta. Para os outros equipamentos, deve-se consultar $\circ$ fabricante para verificar a possibilidade de calibrar esse posicionamento para uma situação eucêntrica. A preservação da região central facilita a identificação de regiões iguais nas imagens do par estéreo, 
produzindo um resultado final mais preciso e com menor tempo em termos de processamento.

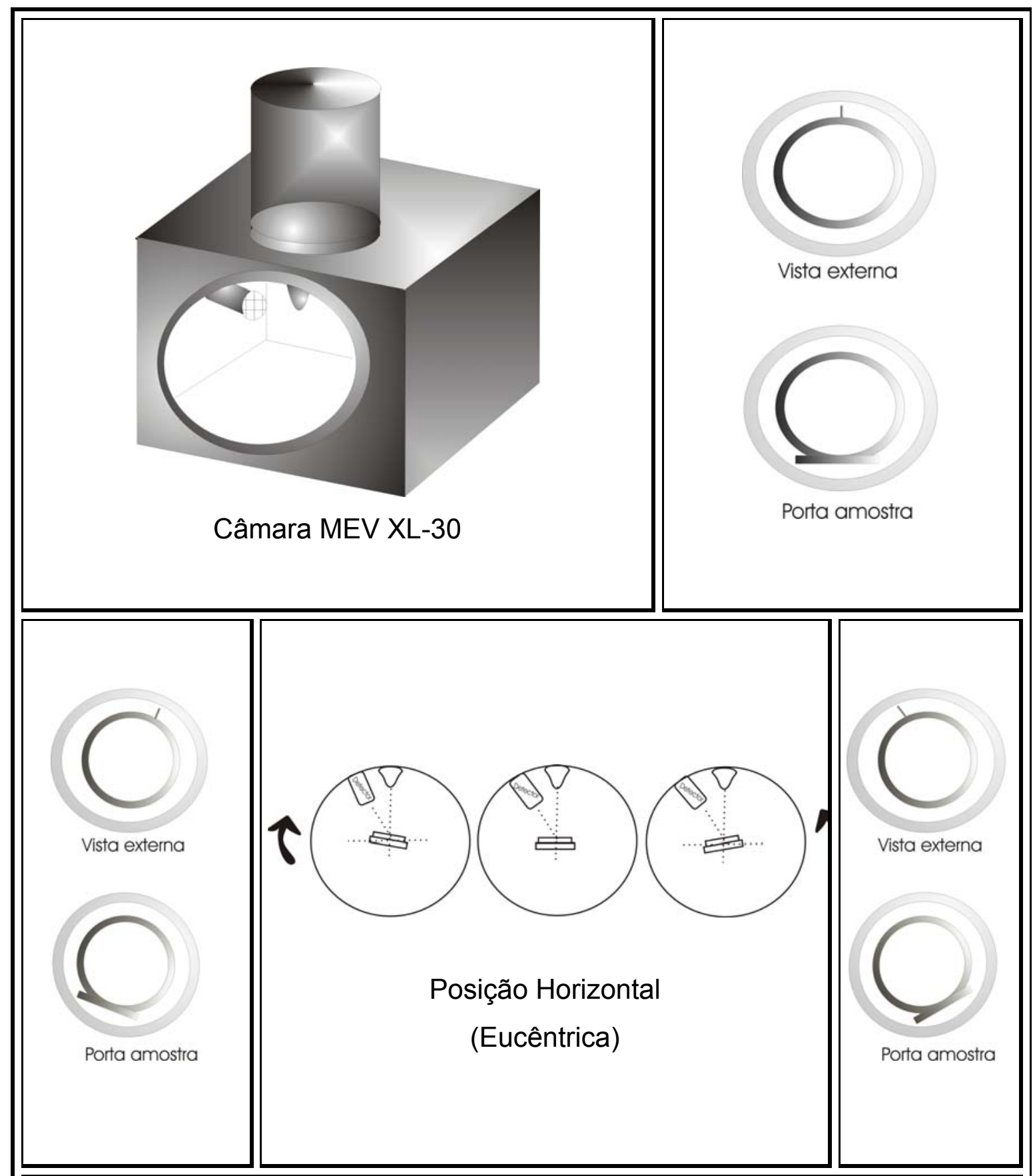

Figura 19: Esquema da câmara do MEV XL-30 e as alterações de posicionamento durante inclinações nos sentidos, horário e anti-horário. 
Amostras grandes dificultam o posicionamento eucêntrico, pois durante as inclinações podem tocar o detector e danificar o equipamento. Como precaução, alguma característica pode ser marcada na tela (no MEV, modelo $X L 30$, as teclas CTRL + X marcam um " $X$ " no centro da imagem) e um cuidado especial deve ser tomado para não alterar a distância de trabalho ao adquirir as duas imagens. Quanto melhor a manutenção do posicionamento das características da imagem, mais rápida e precisamente o programa irá conseguir alinhar as duas imagens.

Um outro ponto a ser considerado é o limite da inclinação que pode ser realizada com as amostras, pois o posicionamento do detector de elétrons secundários está em uma posição inclinada com relação ao eixo vertical, de incidência do feixe eletrônico. À medida que o porta-amostra se inclina no sentido anti-horário ou horário ocorre respectivamente uma aproximação ou oposição da região de interesse com relação ao detector. Quanto mais próximo ao detector, maior será o brilho da imagem, pois um número maior de elétrons secundários alcança o detector para formar a imagem. À medida que a região se opõe ao detector, seu brilho diminui, pois uma quantidade menor dos elétrons que atinge a superfície consegue chegar ao detector, que está em posição contrária. O programa que realiza a reconstrução faz uma equalização das imagens para que essa diferença em brilho não afete a identificação de regiões equivalentes nas imagens do par estéreo.

No modelo $X L-30$, a amostra pode ser inclinada em um ângulo $<90^{\circ}$, no sentido anti-horário, pois nada impede essa movimentação. No sentido horário a limitação é de $10^{\circ}$, conforme especificado pelo fabricante, pois é nesse lado da câmera que o detector de elétrons secundários está posicionado.

A inclinação no sentido anti-horário aproxima a amostra do detector, aumentando seu brilho, até o momento que o feixe se posiciona paralelo a superfície de fratura da amostra, impossibilitando a formação de imagem. No sentido horário, a amostra se opõe ao detector, perdendo brilho, até a posição 
que se torna impossível a formação da imagem, pois os elétrons não conseguem atingir o detector. Dessa forma, ao se utilizar ângulos de inclinação iguais nos dois sentidos, o limite superior de inclinação passa a ser de $10^{\circ}$.

Para verificar os limites de inclinação do porta-amostras, para diferentes materiais, com características diversas em rugosidade foi realizada uma varredura em inclinação, em ambos sentidos, com intervalo de $1^{\circ}$, para superfícies de fratura de cobre, alumínio e compósito CFRP.

A análise dos resultados foi realizada através dos histogramas de cada uma das imagens, para verificar o comportamento das características topográficas de fratura com relação à inclinação imposta. As figuras de 20 a 23 apresentam os resultados para as amostras de cobre e alumínio, em diversos ângulos de inclinação, nos sentidos, horário (-) e anti-horário (+). O resultado esperado para a análise dos histogramas das imagens adquiridas em cada inclinação deveria apresentar apenas a alteração em brilho, conforme a distância entre a região de interesse e o detector.

Nas imagens das superfícies de alumínio, da figura 20, é possível verificar a variação em brilho para cada sentido de inclinação, pela simples observação das imagens. Os histogramas referentes às imagens são apresentados na figura 21, onde é possível observar o deslocamento a esquerda e a direita, durante a inclinação da amostra.

Embora o comportamento tenha ocorrido como o esperado, o mesmo teste foi realizado com as amostras de cobre e de compósito CFRP, para confirmar a tendência dos dados. Os resultados para o cobre são apresentados nas figuras 22 e 23. Embora as inclinações tenham sido variadas em até $\pm 7^{\circ}$, apenas algumas imagens são apresentadas, não só das amostras de cobre como as de alumínio, para dar idéia da variação em brilho que ocorre durante as inclinações. 
Sentido anti-horário

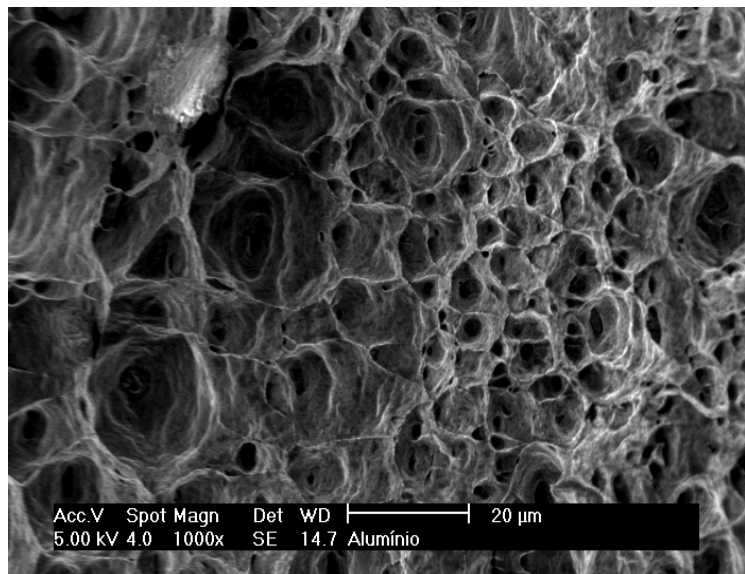

$+1^{\circ}$

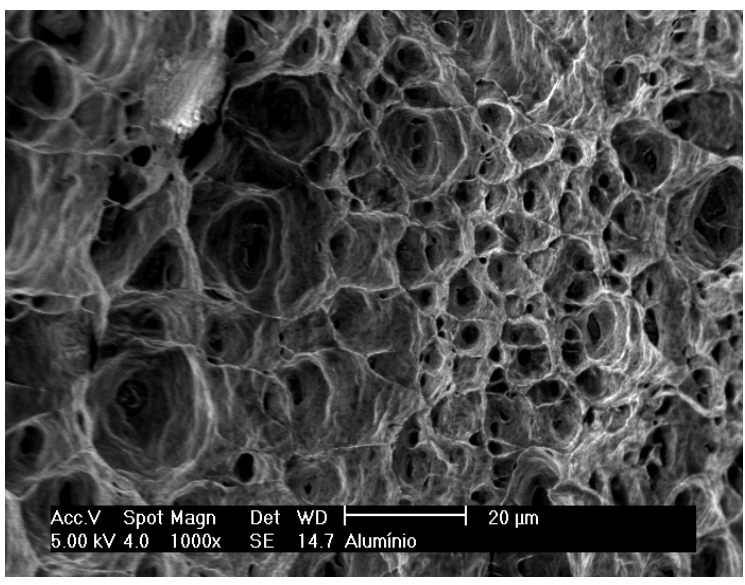

$+2^{\circ}$

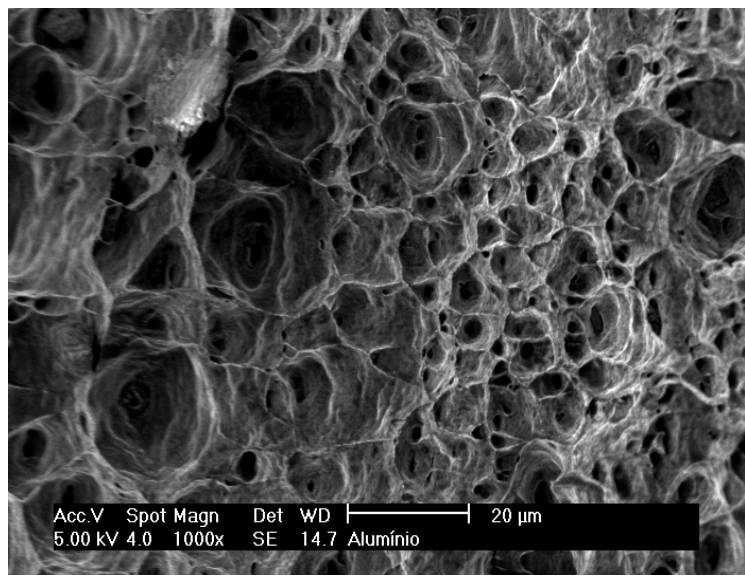

$+3^{\circ}$
Sentido horário

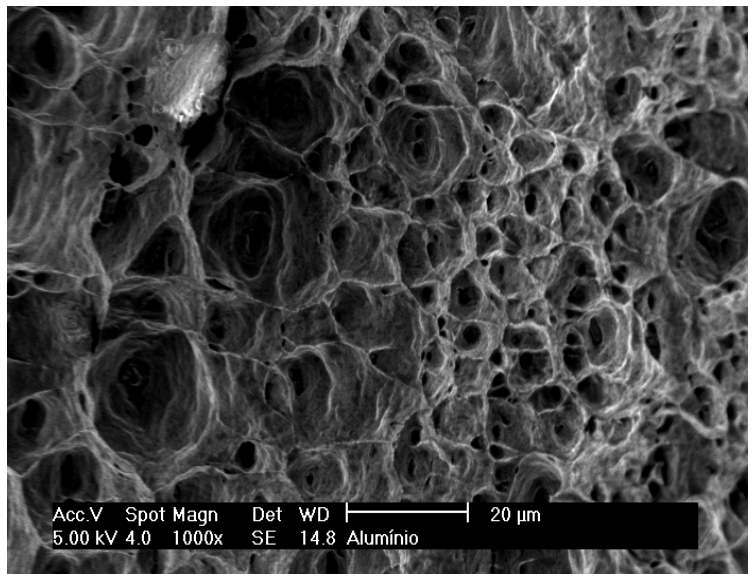

$-1^{\circ}$

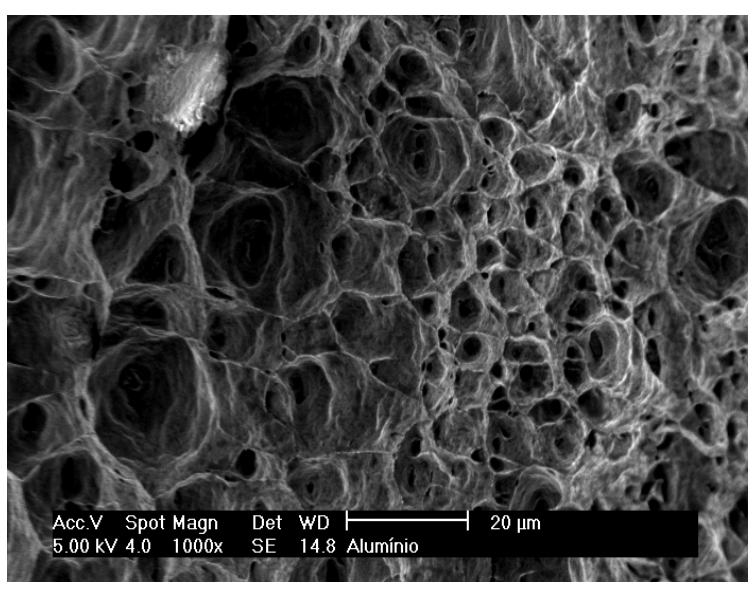

$-2^{\circ}$

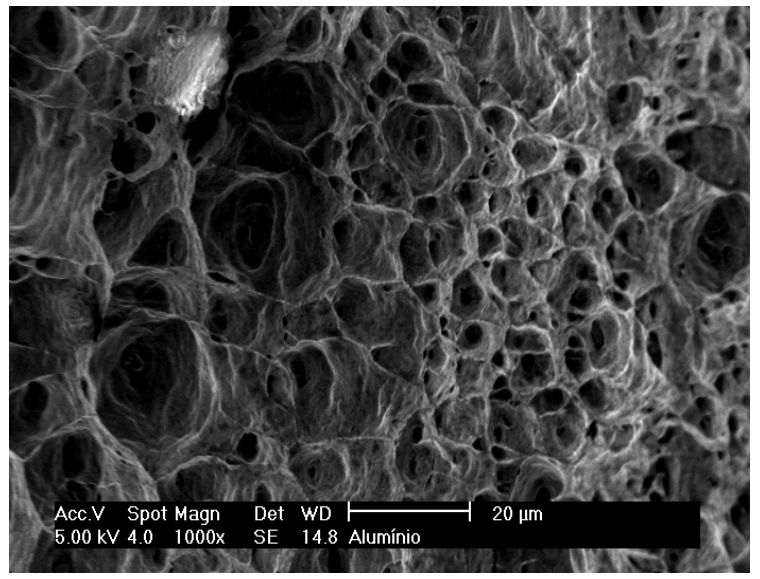

$-3^{\circ}$

Figura 20: Imagens de par estéreo de amostra de superfícies de fratura de Al, inclinadas em até $\pm 3^{\circ}$, nos sentidos anti-horário e horário. 


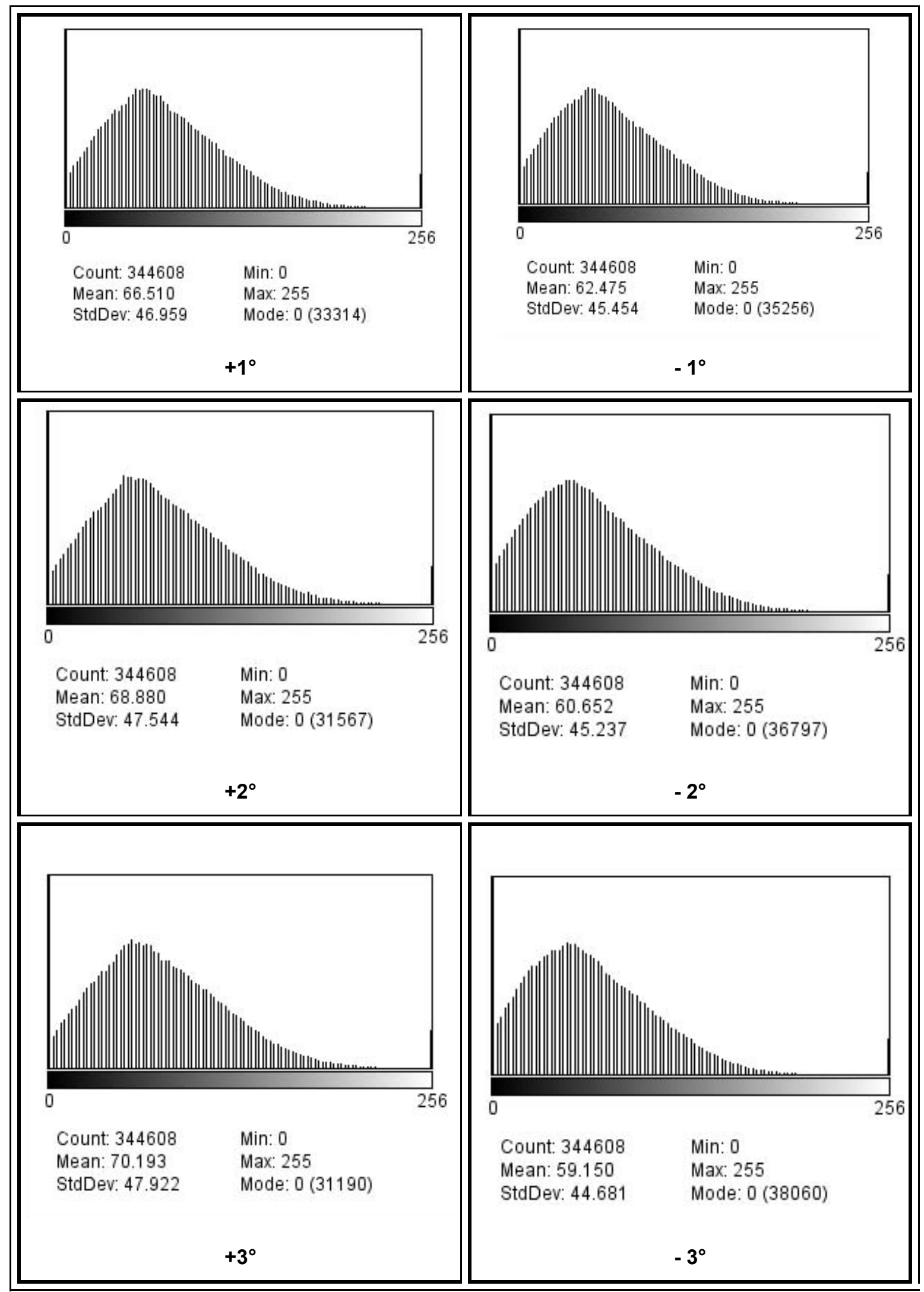

Figura 21: Histogramas das imagens de superfícies de fratura de $\mathrm{Al}$, inclinadas em até $\pm 3^{\circ}$, nos sentidos anti-horário e horário. 


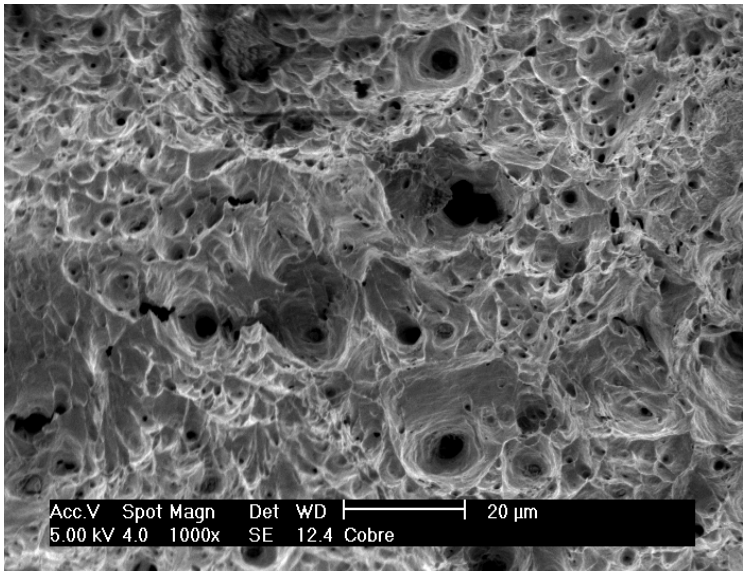

$-2^{\circ}$

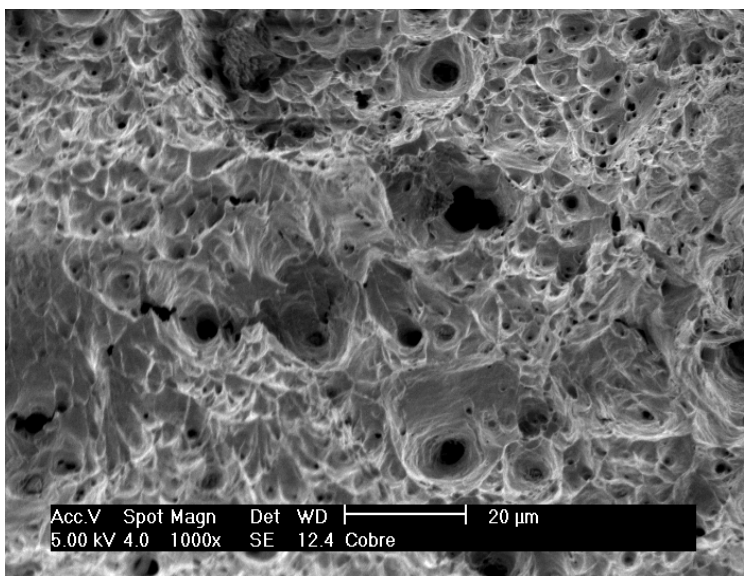

$-4^{\circ}$

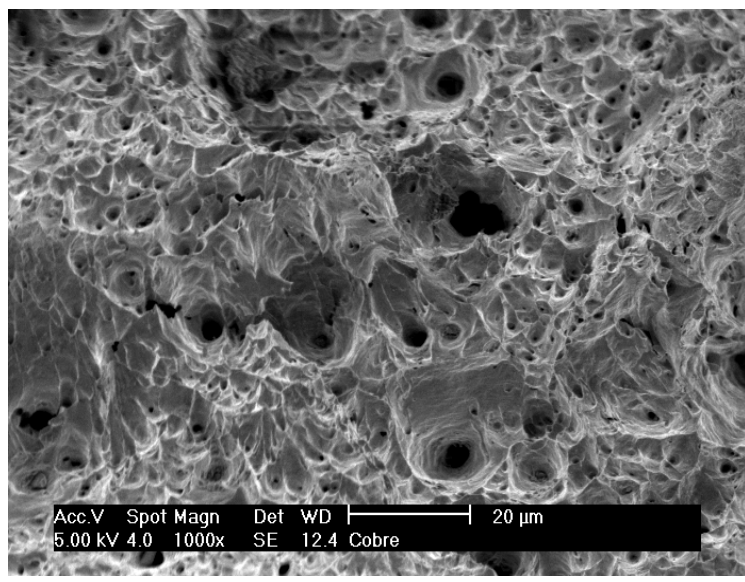

$-6^{\circ}$

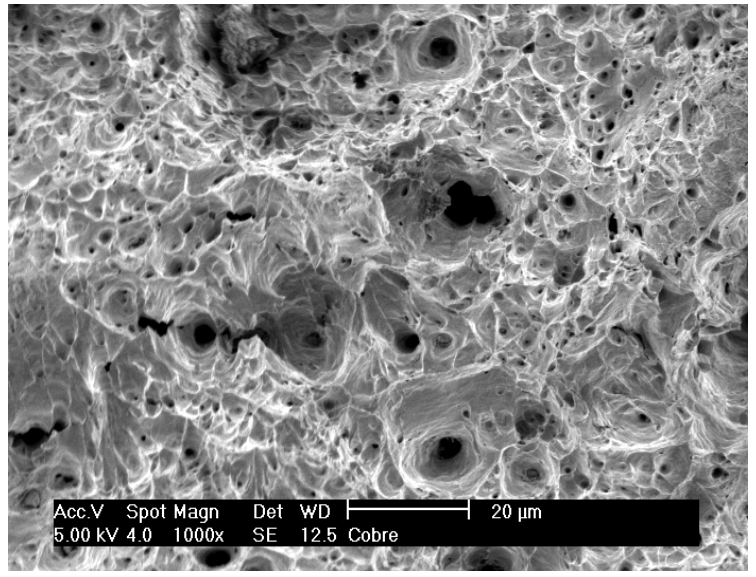

$+2^{\circ}$

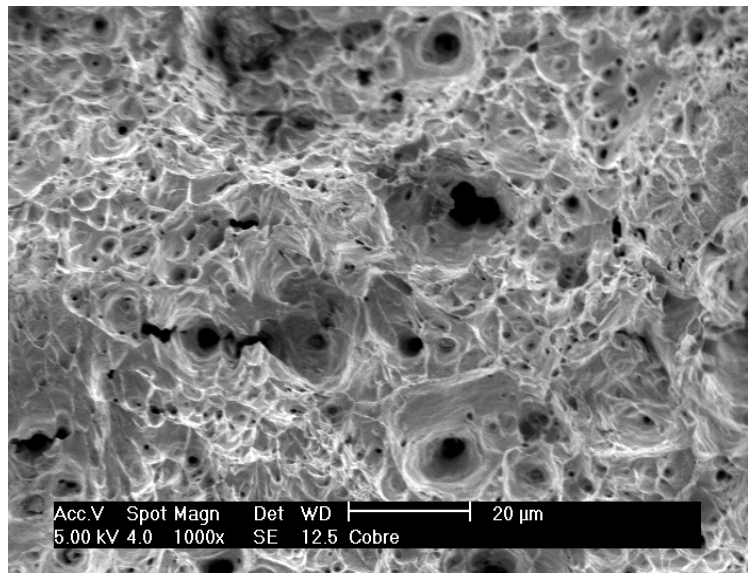

$+4^{\circ}$

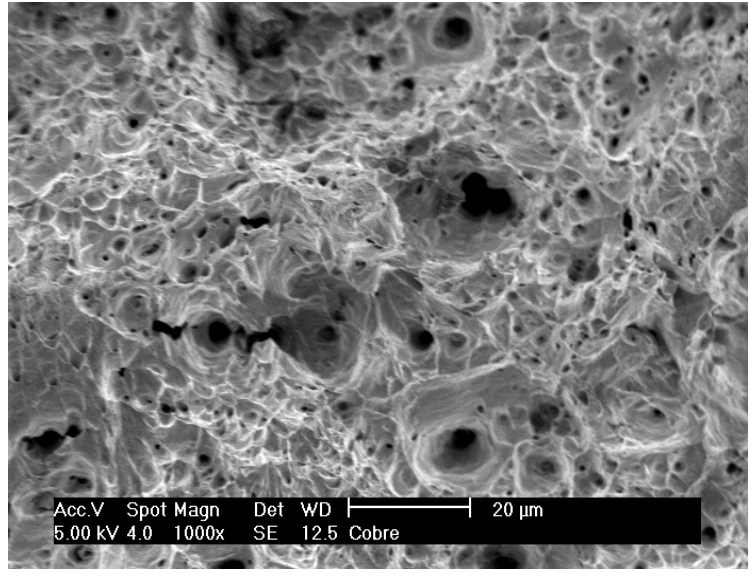

$+6^{\circ}$

Figura 22: Exemplos das imagens de superfícies de fratura de $\mathrm{Cu}$, inclinadas nos sentidos horário e anti-horário . 


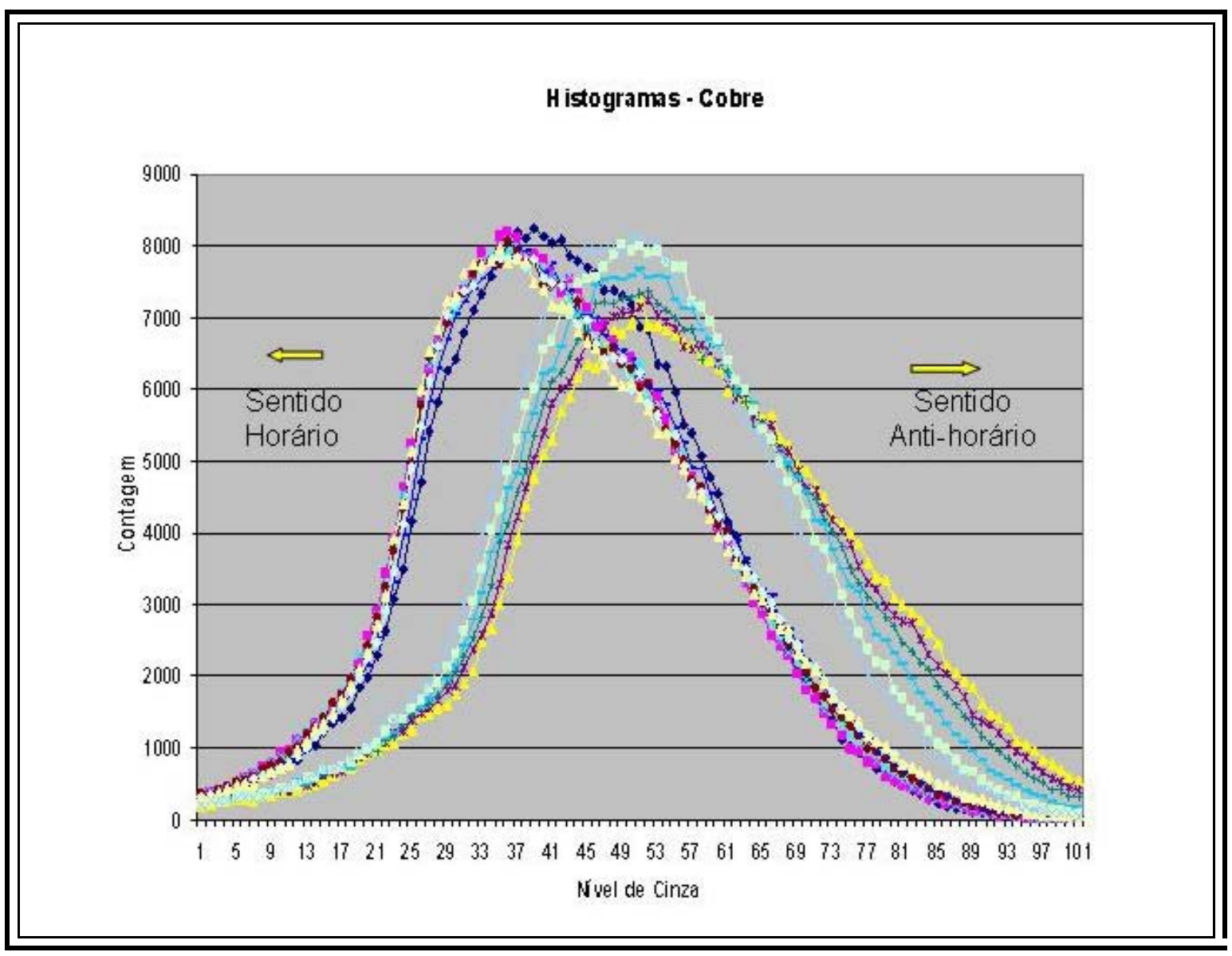

Figura 23: Histogramas das imagens de superfície de fratura de amostras de cobre, inclinadas em até $\pm 6^{\circ}$, nos sentidos anti-horário e horário.

As imagens de cobre foram adquiridas nas mesmas condições que as imagens de alumínio. Os resultados tanto em termos visuais, como através dos histogramas, obedeceram a mesma tendência de deslocamento observada nas amostras de alumínio.

A análise através dos histogramas das superfícies de cobre, apresentadas em um único gráfico na figura 23 , fica mais nítida com relação à observação do deslocamento das curvas de níveis de cinza, para a esquerda, inclinações no sentido horário, a tendência de se opor ao detector, perdendo brilho e, a tendência para um afastamento para a direita, aumentando o brilho, quando a inclinação, no sentido anti-horário, aproxima a superfície do detector. 
Esses dois resultados levariam a conclusão de que não há limite para a inclinação das amostras para a aquisição do par estéreo, parecendo ser uma tendência natural apenas o deslocamento devido ao posicionamento das superfícies. Mas, ao analisar os resultados obtidos para o compósito CFRP, é possível observar que, embora as conclusões tiradas não estejam erradas, elas só são válidas para superfícies de fratura que apresentam uma rugosidade com pequenas diferenças em altura. Esses resultados, que apresentam a mesma tendência para a análise das superfícies de fratura das amostras de cobre e alumínio não se repetem com as amostras de compósitos CFRP.

As imagens adquiridas para o material compósito CFRP (figura 24) apresentam uma rugosidade bem acentuada, com uma grande variação em altura, devido à presença predominante de arrancamento das fibras. Os histogramas do material compósito são apresentados na figura 25 , com resultados em separado para as inclinações nos sentidos, horário e antihorário, com inclinações de $\pm 7^{\circ}$. No sentido anti-horário, os histogramas são compatíveis com os dos outros materiais analisados, ou seja, a superfície de interesse está se aproximando do detector e seu brilho está aumentando.

No sentido horário, à medida que a amostra é inclinada, além do deslocamento para a esquerda, numa região de menor brilho, a forma do histograma se altera quando ocorre uma oposição da superfície em relação ao detector e aparecem registros associados ao da região de interesse, que antes não ocorriam. As variações em contagem ocorrem mais visivelmente entre os níveis intermediários de cinza, reforçando a observação de que novos elementos estão sendo visualizados na região, provavelmente da lateral da amostra, que possui variações consideráveis em altura. 

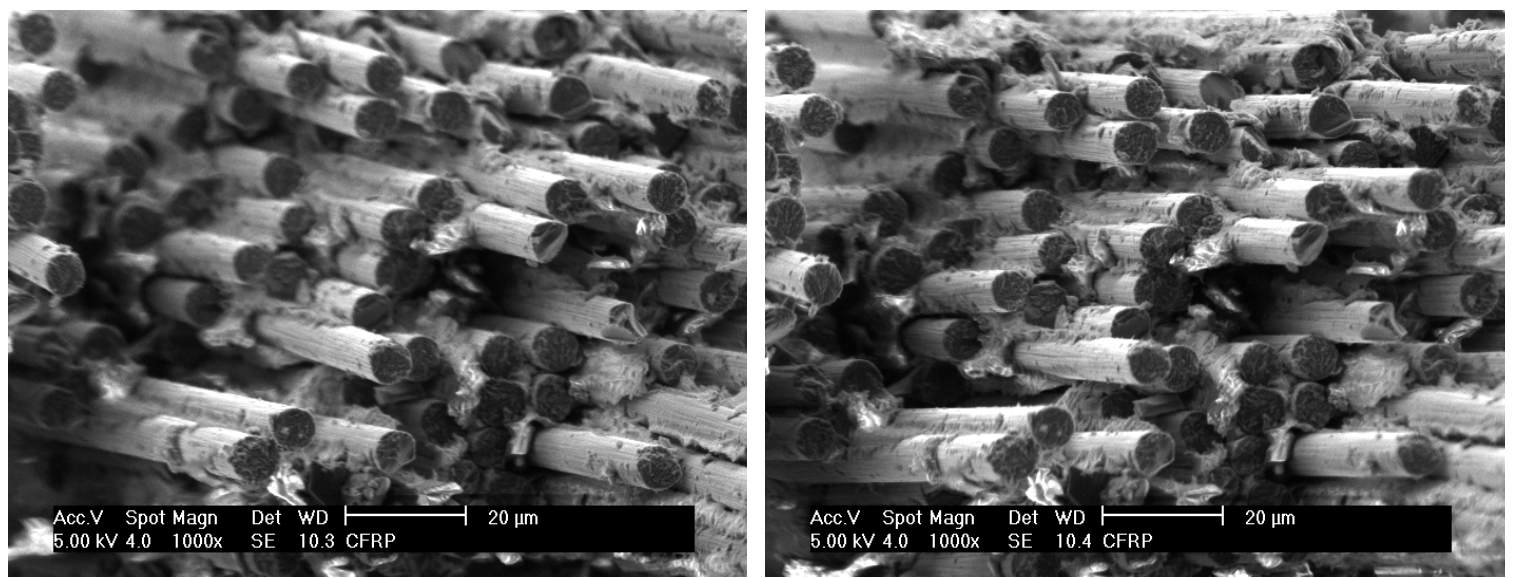

$\pm 2^{\circ}$
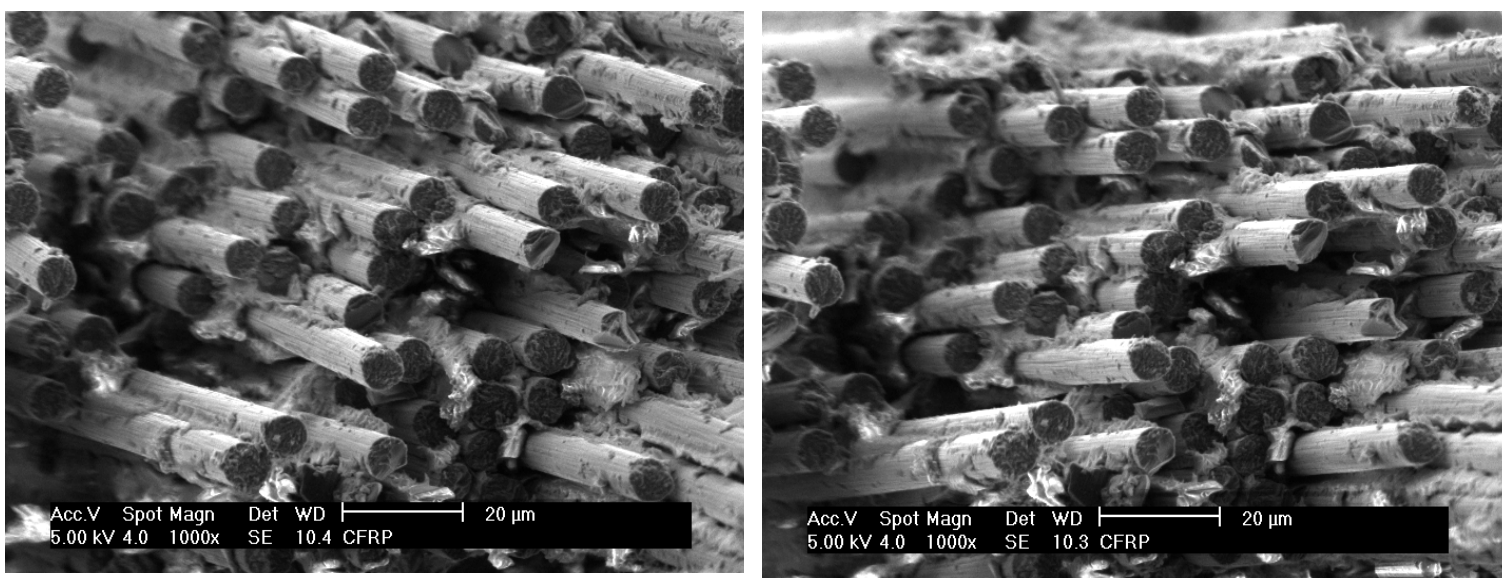

$\pm 4^{\circ}$
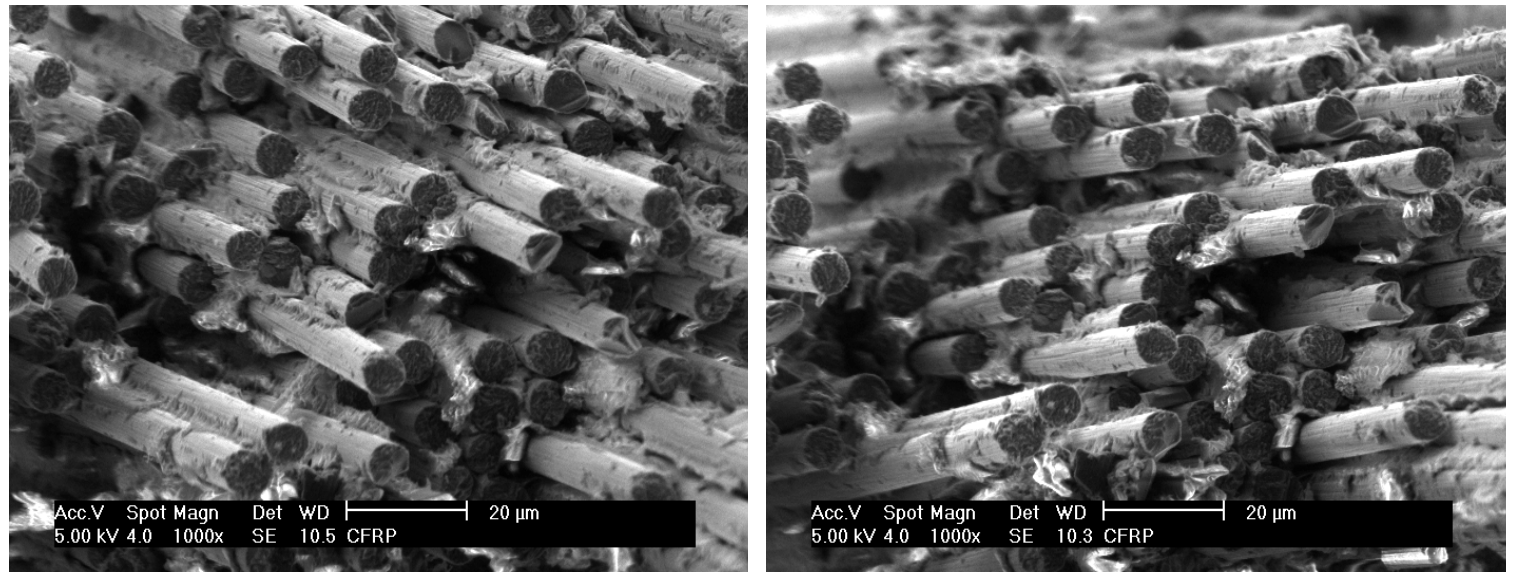

$\pm 6^{\circ}$

Figura 24: Imagens de superfície de fratura de material compósito CFRP nos sentidos horário (coluna à esquerda) e anti-horário (coluna à direita). 
Sentido horário

Sentido anti-horário

\begin{tabular}{|c|c|c|}
\hline $1^{\circ}$ & $\begin{array}{l}9000 \\
8000 \\
7000 \\
6000 \\
5000 \\
4000 \\
3000 \\
2000 \\
1000 \\
0\end{array}-{ }_{1}^{\prime}$ & $\left.\begin{array}{lllllllll}8000 \\
7000 \\
6000 \\
5000 \\
4000 \\
3000 \\
2000 \\
1000\end{array}\right]_{0}^{\prime}$ \\
\hline $2^{\circ}$ & $\left.\begin{array}{l}9000 \\
8000 \\
7000 \\
6000 \\
5000 \\
4000 \\
3000 \\
2000 \\
1000\end{array}\right]$. & $\left.\begin{array}{l}8000 \\
7000 \\
6000 \\
5000 \\
4000 \\
3000 \\
2000 \\
1000 \\
0\end{array}\right]$ m \\
\hline $3^{\circ}$ & $\left.\begin{array}{llllllll}8000 \\
7000 \\
6000 \\
5000 \\
4000 \\
3000 \\
2000 \\
1000\end{array}\right]$ & $\left.\begin{array}{l}7000 \\
7000 \\
6000 \\
5000 \\
4000 \\
3000 \\
2000 \\
1000\end{array}\right]_{0}$ \\
\hline $4^{\circ}$ & $\left.\begin{array}{l}9000 \\
8000 \\
7000 \\
6000 \\
5000 \\
4000 \\
3000 \\
2000 \\
1000\end{array}\right]$ & $\left.\begin{array}{l}8000 \\
7000 \\
6000 \\
5000 \\
4000 \\
3000 \\
2000 \\
1000\end{array}\right]$ \\
\hline $5^{\circ}$ & $\begin{array}{l}8000 \\
7000 \\
6000 \\
5000 \\
4000 \\
3000 \\
2000 \\
1000\end{array}$ & 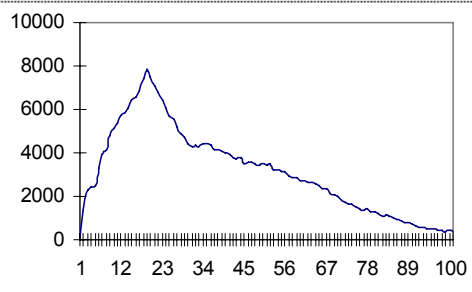 \\
\hline $6^{\circ}$ & $\left.\begin{array}{l}8000 \\
7000 \\
6000 \\
5000 \\
4000 \\
3000 \\
2000 \\
1000 \\
0\end{array}\right]$ m & $\begin{array}{lllllll}8000 \\
7000 \\
6000 \\
5000 \\
4000 \\
3000 \\
2000 \\
1000\end{array}$ \\
\hline $7^{\circ}$ & $\begin{array}{l}8000 \\
7000 \\
6000 \\
5000 \\
4000 \\
3000 \\
2000 \\
1000\end{array}$ & $\begin{array}{l}9000 \\
8000 \\
7000 \\
6000 \\
5000 \\
4000 \\
3000 \\
2000 \\
1000\end{array}$ \\
\hline
\end{tabular}

Figura 25: Histogramas das imagens de superfície de fratura de materiais compósito,

inclinadas em até $\pm 7^{\circ}$. 
O limite de inclinação das amostras deve levar em conta se suas superfícies apresentam baixa rugosidade e podem ser inclinadas, em ambos os sentidos, sem que haja alteração das condições de observação. Quando a rugosidade da superfície for elevada, como no caso dos materiais compósitos do tipo CFRP, é importante fazer uma verificação nos limites de inclinação, no sentido horário, para verificar a influência dessa variação em altura, nos resultados finais.

Essas observações são suficientes para impor um limite de inclinação da amostra menor que $\pm 2^{\circ}$, para o caso das superfícies de compósitos analisadas, com rugosidade acentuada, para que durante a inclinação não sejam alteradas as características da superfície desejada. Uma inclinação maior ou igual a $2^{\circ}$, no sentido horário, começa a revelar a influência da região lateral durante a aquisição da imagem.

Ao analisar os possíveis erros na obtenção do valor das projeções, para a construção do mapa de elevações, por meio da equação apresentada na figura 8 , pode-se notar que uma pequena diferença entre as projeções à esquerda e à direita deve ser evitada para que o resultado não se torne próximo de zero ou inexpressivo em termos de elevação. Isto implica em uma limitação na paralaxe $\Delta \theta$, para valores muito pequenos, ou seja, quanto menor o ângulo entre as inclinações, pior será o resultado. Porém, para os compósitos CFRP, se um ângulo maior que $4^{\circ}$ for necessário para a reconstrução, as imagens utilizadas não podem manter as mesmas condições para as regiões de interesse.

O método da reconstrução por paralaxe não pode ser aplicado para materiais compósitos CFRP nas condições até agora empregadas, de um par de ângulos simétricos. As imagens devem ser obtidas para ângulos maiores que $4^{\circ}$, tomados apenas em uma direção, com inclinações no sentido antihorário. O mesmo programa pode ser utilizado para obter a reconstrução, sendo que o grande inconveniente desse processo é que a região reconstruída não vai ser a observada com a amostra na posição horizontal inicial, mas sim 
na inclinação correspondente a metade do ângulo total entre as inclinações utilizadas.

A figura 26 mostra o resultado de reconstrução de duas imagens adquiridas a $1^{\circ}$ e $6^{\circ}$ de inclinação, no sentido anti-horário. O mapa de elevações gerado pode ser considerado como um bom resultado de reconstrução quanto a reprodução da superfície original. Porém, essa imagem foi adquirida da superfície de fratura de um compósito unidirecional, que possui uma superfície com pequena variação em rugosidade.

A reconstrução de uma superfície de compósito multidirecional foi realizada a partir das imagens mostradas na figura 27, adquiridas com inclinação de $1^{\circ}$ e $8^{\circ}$ respectivamente, no sentido anti-horário. Ao se tentar rodar o programa, fazendo a opção por um alinhamento das imagens, erros começam a aparecer e interrompem o processamento, mostrando que para uma superfície, cuja rugosidade é caracterizada por uma grande variação em altura, a rotina deve ser repensada.

A rotina que realiza o alinhamento das imagens, extrai uma janela da região esquerda superior da imagem referência ( a de menor inclinação) e tenta identificar uma região semelhante na imagem de busca (a de maior inclinação), através de uma busca no plano xy, para estabelecer o ângulo de correção da rotação e o valor da translação sofrida pela imagem de busca, em relação a imagem referência.

Pela simples observação das imagens do compósito multidirecional é possível notar que há uma grande diferença entre elas, e que a busca de regiões semelhantes deve se restringir a parte central da imagem, que é a mais preservada durante a inclinação da amostra. Com uma pequena região de referência, seria mais provável encontrar uma região semelhante e calcular os valores para rotação e translação da imagem de busca, como mostram as figuras 28 e 29. 
(a)
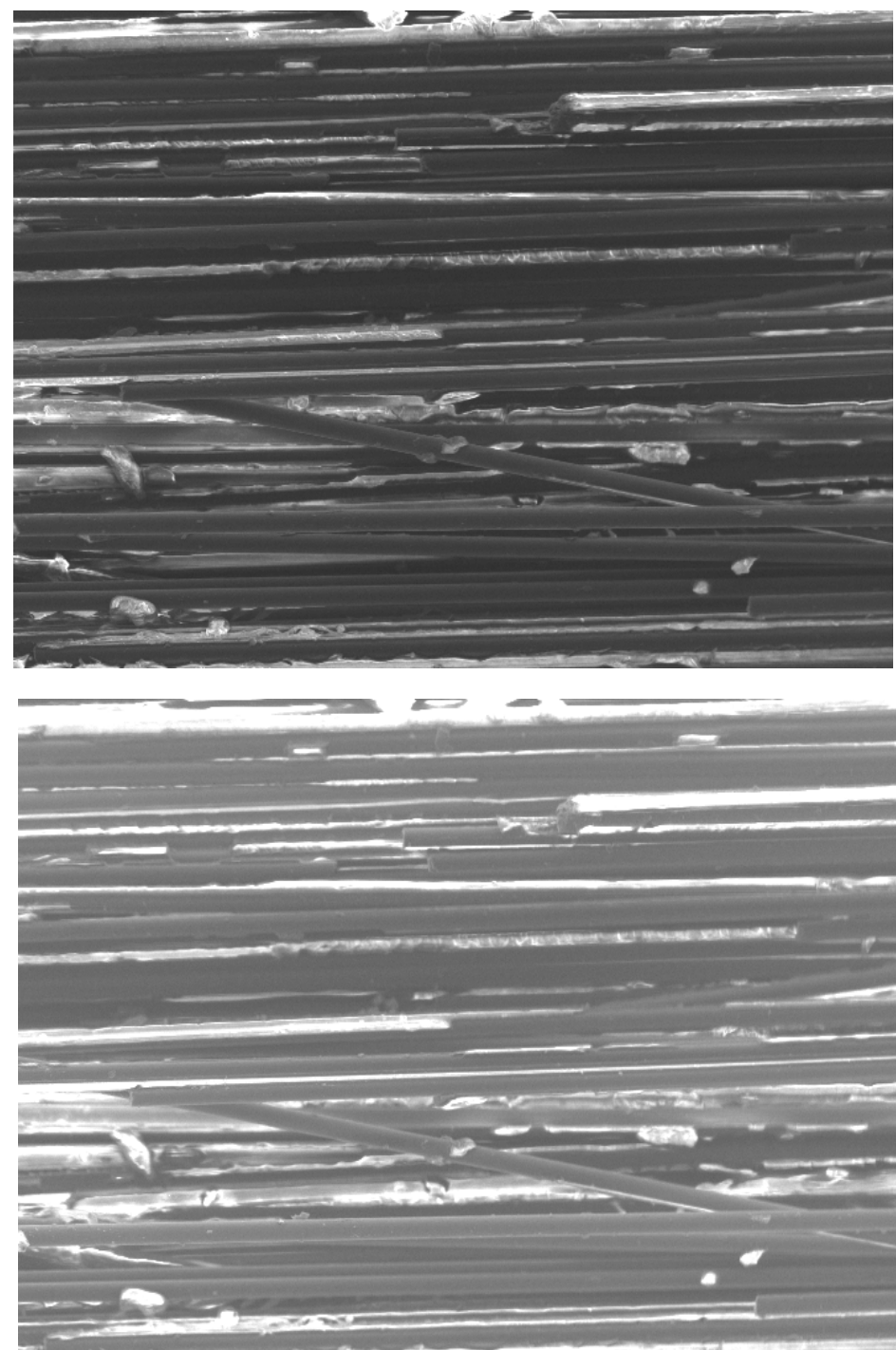

$6^{\circ}$

(b)
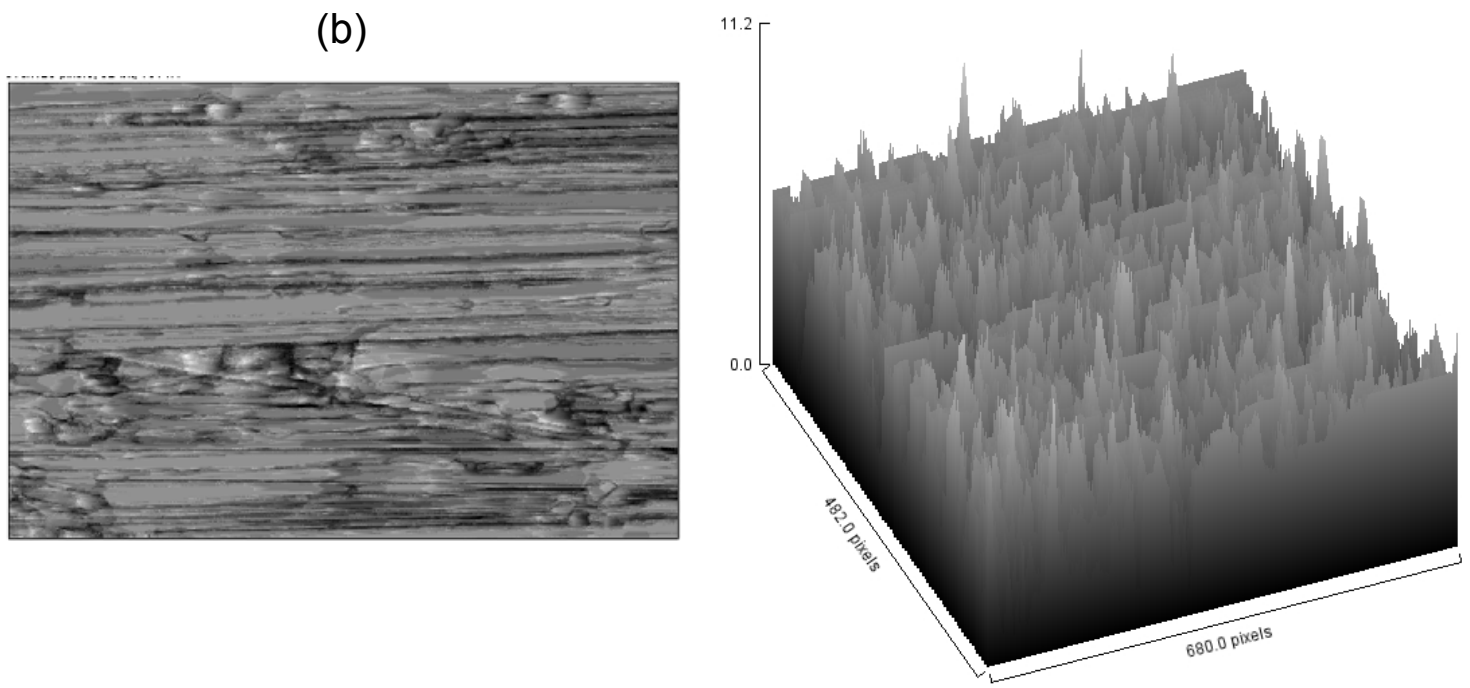

Figura 26: Reconstrução de superfície de fratura de material compósito: (a) imagens originais com inclinação de $1^{\circ}$ e $6^{\circ}$; (b) mapa de elevações em $2 D$ e $3 D$. 

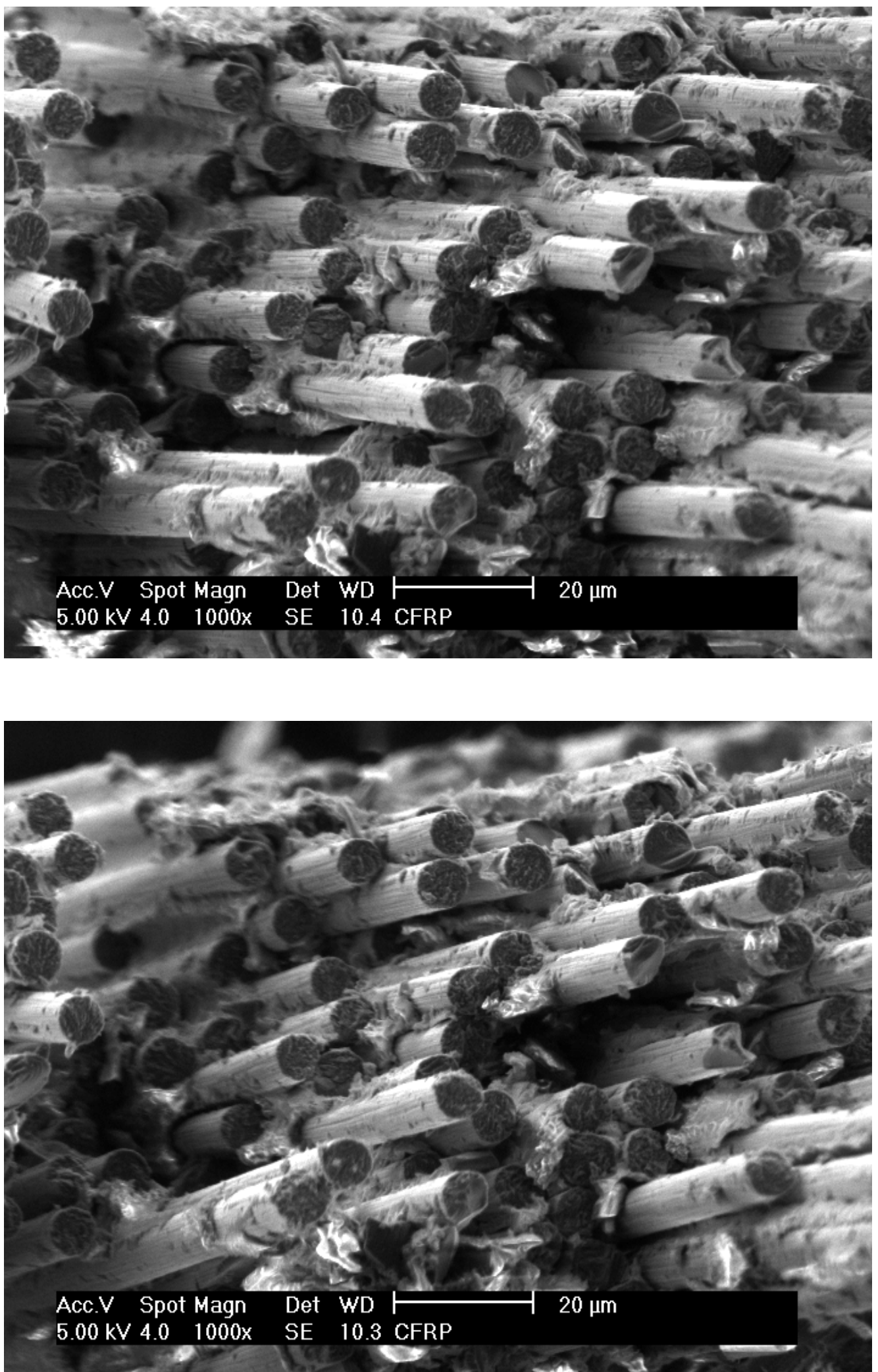

Figura 27: Par de imagens Mev, adquiridas a $1^{\circ}$ e $8^{\circ}$ respectivamente, utilizadas para reconstrução de compósito multidirecional. 

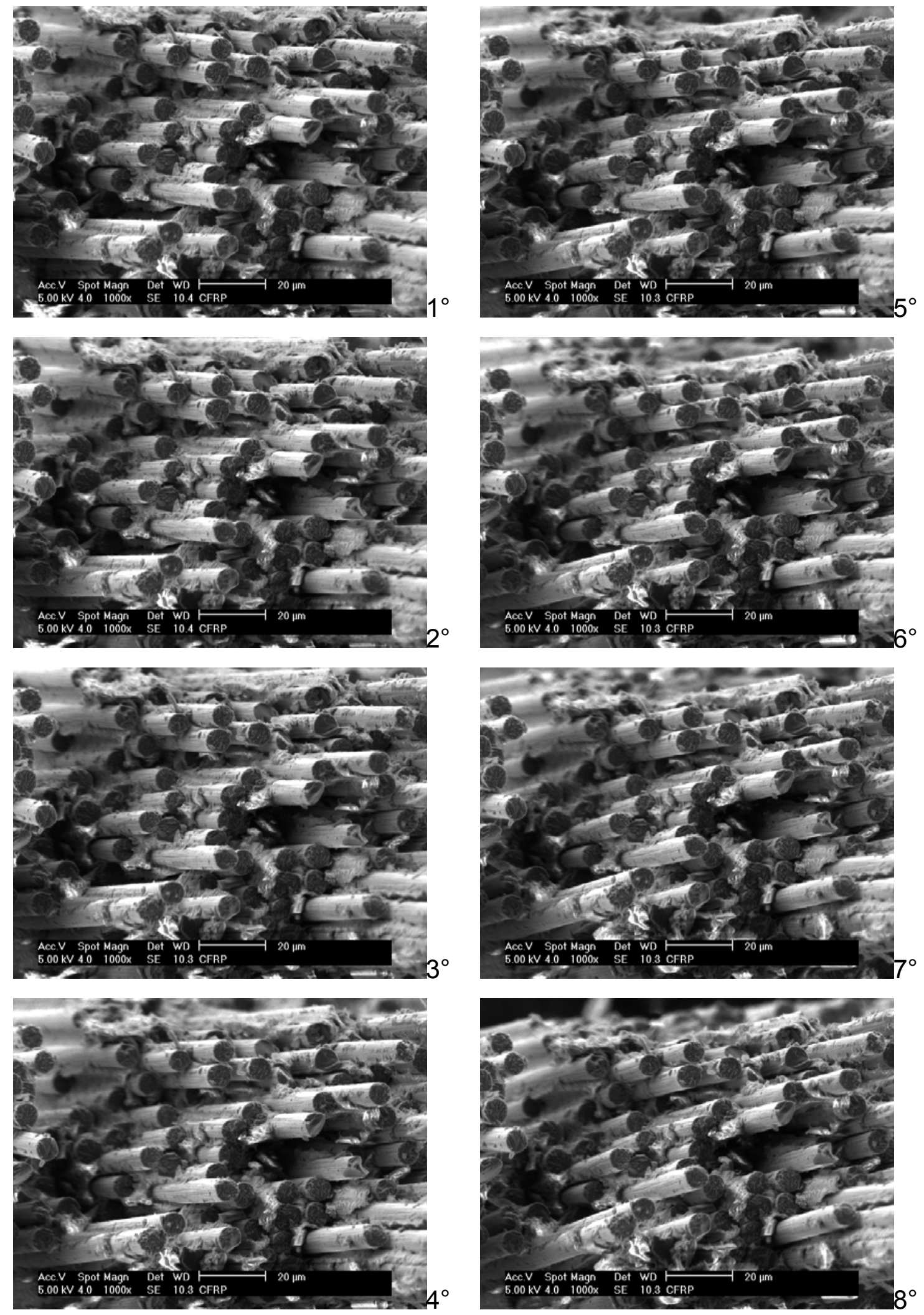

Figura 28: Imagens de CFRP, inclinadas de $1^{\circ}$ a $8^{\circ}$, no sentido anti-horário. 

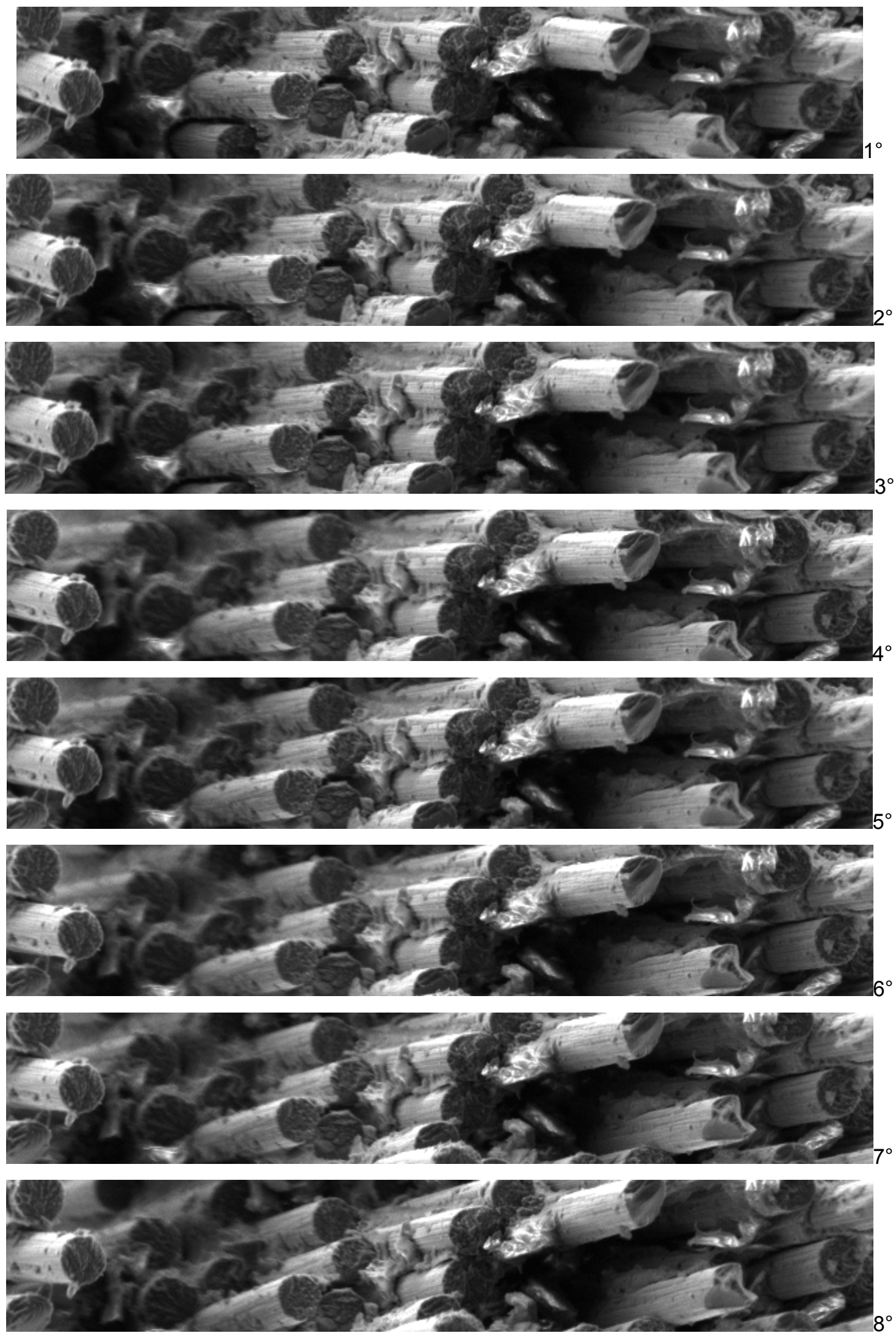

Figura 29: Partes centrais das imagens da figura 28, de CFRP inclinadas de $1^{\circ}$ a $8^{\circ}$. 
Para alterar a rotina, uma região de interesse (ROI) próxima a região central pode ser estabelecida, um retângulo de tamanho fixo posicionado no centro da imagem, sem a necessidade da intervenção do operador. A busca pela região semelhante seria mais rápida e mais precisa e daria como resultado o deslocamento sofrido pela região, que corresponderia ao deslocamento horizontal da imagem inteira.

A determinação do alinhamento em $X$ ainda não coloca todas as características nas mesmas posições, que pela própria inclinação da amostra, produz um deslocamento na vertical. A busca, portanto, fica restrita a uma comparação na vertical, para um dado posicionamento.

A imagem de busca será alterada de acordo com os deslocamentos estabelecidos pelo alinhamento e as imagens poderão ser comparadas para a determinação da elevação pixel a pixel, através da diferença entre os valores de projeções encontrados em cada uma das imagens.

A preocupação com o tempo de processamento deve ser relevada a segundo plano, considerando que a qualidade e precisão da reconstrução tridimensional seja o objetivo a ser atingido. A elaboração do programa ainda está em aberto para alterações e é um indicativo para a continuação deste trabalho.

$\mathrm{Na}$ prática, algumas das observações importantes para serem introduzidas no programa de reconstrução tridimensional de imagens MEV serão apresentados a seguir:

A aquisição das imagens deve obedecer as observações quanto a manutenção do posicionamento da região de interesse centralizada na imagem e, para que os deslocamentos em XY sejam os menores possíveis para não dificultarem o casamento das imagens. 
As imagens devem ser adquiridas no sentido anti-horário de inclinação, como mostra o esquema abaixo (figura 30). Tomando esse cuidado é possível reconstruir superfícies com rugosidade suave ou acentuada, o que torna o programa mais abrangente, e não obriga a qualquer restrição em inclinação para as amostras.

O fato das imagens serem tomadas em uma única direção altera o processamento para o cálculo das alturas em cada ponto da imagem após a inclinação.

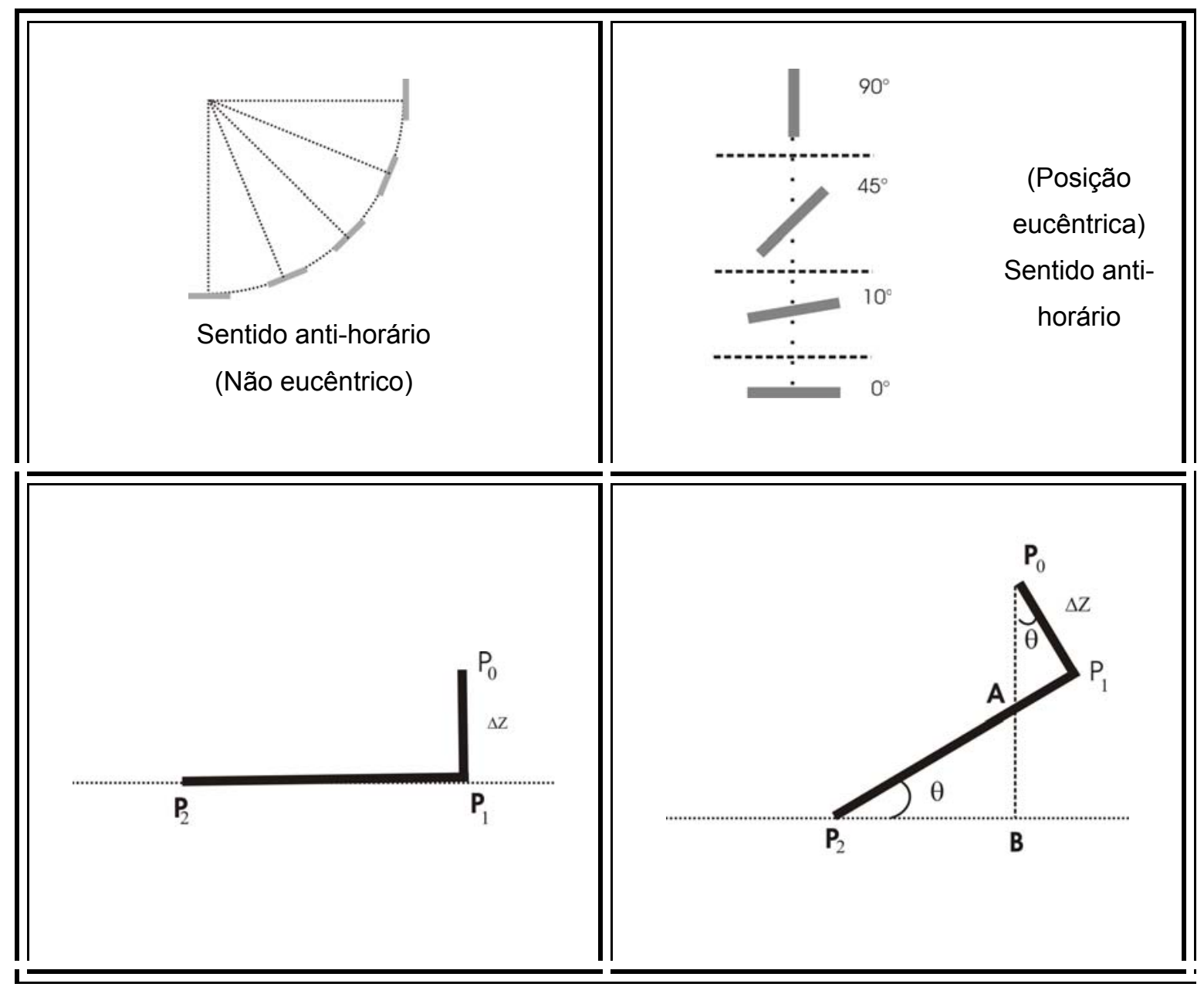

Figura 30: Esquema mostrando inclinações em sentido anti-horário e a projeção de uma característica de altura $\Delta Z$. 
A projeção da altura $\Delta Z$, de uma determinada elevação da amostra, em uma imagem, após ser inclinada em um ângulo $\theta$ é dada por:

$$
\begin{gathered}
\operatorname{tg}(\Delta \theta)=\frac{A P_{1}}{\Delta Z} \\
A P_{1}=\Delta Z \times \operatorname{tg}(\theta)
\end{gathered}
$$

Onde, $\theta$ é o ângulo de inclinação da imagem com relação a horizontal, $\Delta Z$ é a elevação em um ponto da imagem e, $\mathrm{AP}_{1} \mathrm{o}$ valor de sua projeção na imagem mais inclinada. Para o cálculo da elevação na imagem reconstruída através do par estéreo, deve-se considerar a ampliação das imagens(M):

$$
\begin{gathered}
\Delta P_{1}=\Delta Z_{1} \times \operatorname{tg}\left(\theta_{1}\right) \\
\Delta P_{2}=\Delta Z_{2} \times \operatorname{tg}\left(\theta_{2}\right) \\
\Delta Z=\Delta Z_{2}-\Delta Z_{1} \\
\Delta Z=\frac{1}{M}\left(\frac{\Delta P_{2}}{\operatorname{tg}\left(\theta_{2}\right)}-\frac{\Delta P_{1}}{\operatorname{tg}\left(\theta_{1}\right)}\right)
\end{gathered}
$$

Desta forma, o valor individual da projeção sobre a amostra aumentará linearmente com o aumento do ângulo de inclinação, conforme mostra o gráfico da figura 31, para ângulos de inclinação $\leq 20^{\circ}$. Para determinar a projeção em um ângulo desse intervalo, bastaria uma interpolação.

A linearidade no valor das projeções abre também a possibilidade de realizar a reconstrução com imagens múltiplas, no mesmo sentido de inclinação anti-horário, que melhorariam a precisão dos cálculos, através de uma média de valores de elevação. 


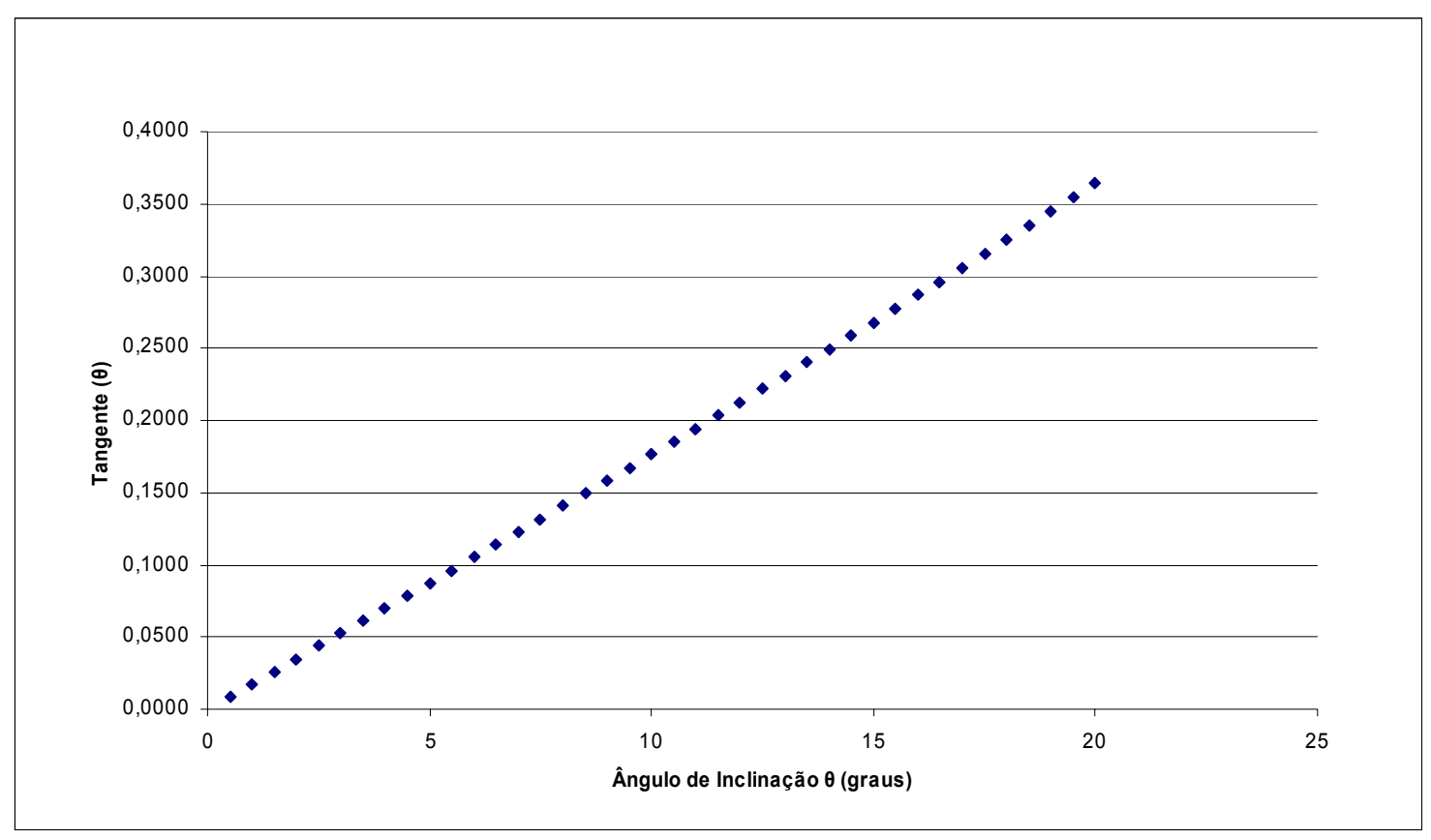

Figura 31: Gráfico da variação da tangente de $\theta$ em função do ângulo de inclinação, mostrando a linearidade para o cálculo de projeções na imagem.

A necessidade de intervenção de um usuário externo deve se ater a um mínimo de informação, como por exemplo, indicar o valor do ângulo entre as imagens utilizadas. Os outros valores necessários para o programa devem ser estabelecidos a partir desse valor. Essas pequenas alterações tornam 0 programa operacionalmente mais simples.

O fato das imagens serem obtidas no mesmo sentido de inclinação faz com que as projeções ocorram sempre do lado esquerdo e as sobreposições, que possam acontecer na imagem, se deem sempre da direita para a esquerda, o que simplifica a identificação. Portanto as imagens devem ser comparadas sempre nesse sentido, da direita para a esquerda. 


\section{Conclusões}

O primeiro método de reconstrução de superfícies de fratura de material compósito CFRP, analisado no trabalho, foi a reconstrução por foco variável. Este método é muito eficiente e preciso para reconstruir imagens de superfícies que apresentam tanto uma rugosidade com pequenas variações em altura, como para amostras com rugosidade acentuada.

Mesmo com sua limitação em termos de aumento e o tempo desprendido para adquirir a pilha de imagens, esse método é viável para qualquer tipo de amostra observada por microscopia óptica. Com um equipamento considerado como básico em observações microestruturais é possível obter imagens com alta qualidade e fazer uma análise fractográfica abrangente de toda a superfície da amostra.

O método de reconstrução por paralaxe se mostra bem adequado para superfícies com baixa rugosidade, como é o caso dos materiais compósitos unidirecionais. Os resultados de algumas reconstruções tridimensionais, para essas superfícies, mostraram ser bastante representativos da região observada e o mapa de elevações gerado pode ser utilizado para obter os valores de rugosidade de uma região da imagem inicial.

A reconstrução 3D para os materiais compósitos multidirecionais, demonstra que algumas modificações da rotina e métodos de aquisição de imagens devem ser realizados, principalmente pela complexidade de detalhamento das imagens de materiais CFRP.

Existe uma limitação de inclinação da amostra, independentemente do tipo e modelo de equipamento utilizado, quando se realiza inclinações nos sentidos horário e anti-horário, com relação a posição horizontal. As amostras com alta rugosidade ao serem inclinadas no sentido horário apresentam alterações em seus histogramas, demonstrando a interferência da região lateral da amostra durante a aquisição do par estéreo. Não há limite de inclinação de 
amostras se elas forem inclinadas em sentido anti-horário, a partir da posição horizontal, independente do equipamento utilizado.

A reconstrução com imagens adquiridas em um único sentido, sem a alteração da rotina utilizada, irá reconstruir uma região que corresponde à metade do valor total de inclinação. Os resultados dessa reconstrução reforçam a necessidade de alteração da rotina, considerando a aquisição das imagens em um único sentido.

Algumas alterações na rotina são sugeridas, como a determinação de uma região de interesse (ROI), com valor fixo para qualquer tipo de amostra, próxima ao ponto central da imagem, que passa por variações muito pequenas durante a inclinação. Essa alteração faz com que o programa se torne mais abrangente, podendo ser usado para caracterizar materiais com qualquer tipo de rugosidade.

Um novo cálculo para a determinação da elevação local é apresentado e, a linearidade do valor das projeções em função do ângulo de inclinação sugere a possibilidade de reconstrução com múltiplas imagens. 


\section{Apêndice A: Materiais Compósitos}

Os materiais compósitos são formados por dois ou mais componentes com diferentes propriedades, que associados, geram um material com propriedades otimizadas, em relação às propriedades individuais. O aumento na demanda desse material, devido ao aumento de produção e conseqüente redução de custo, o tornaram mais competitivo e permite que sejam encontrados em projetos de diversas áreas de engenharia, onde confiabilidade e desempenho são questões essenciais, como na indústria aeroespacial, nuclear, petroquímica, naval, automotiva, veículos de competição e esportiva.

Essa posição de destaque, somente foi alcançada no final dos anos 60, graças ao desenvolvimento das fibras de carbono, que possibilitou uma grande flexibilidade em termos de projetos. Como podem ser utilizadas na forma de fio ou tecido, oferecem uma facilidade na confecção de peças, como capacetes de várias modalidades esportivas, consideradas complexas para os materiais convencionais.

Os compósitos CFRP (Carbon Fiber Reinforced Polymer) de matriz polimérica de resina epóxi e fibras de carbono contínuas, associam a resistência à degradação química da matriz com as propriedades mecânicas das fibras de carbono. Algumas das principais propriedades desses materiais são apresentadas na tabela $\mathrm{A} 1$.

A resina epóxi é um polímero termofixo, que após a cura, apresenta propriedades mecânicas razoáveis, elevada temperatura de distorção térmica e de transição vítrea, boa resistência ao envelhecimento pelo calor e ótima resistência química. O reforço com fibras de carbono proporciona a associação de elevada resistência mecânica, baixa densidade, alto módulo de elasticidade, além da estabilidade dimensional. 


\begin{tabular}{|c|c|c|c|c|}
\hline & \multirow{2}{*}{$\begin{array}{c}\text { Resina } \\
\text { Epóxi }\end{array}$} & \multicolumn{3}{|c|}{ Fibra de Carbono } \\
\hline & & $\begin{array}{c}\text { Resistência } \\
\text { Elevada }\end{array}$ & $\begin{array}{l}\text { Módulo } \\
\text { Elevado }\end{array}$ & $\begin{array}{c}\text { Módulo } \\
\text { Intermediário }\end{array}$ \\
\hline $\begin{array}{c}\text { Resistência } \\
\text { à } \\
\text { Tração } \\
\text { (MPa) }\end{array}$ & 75 & 3400 & 2350 & 4100 \\
\hline $\begin{array}{c}\text { Módulo de } \\
\text { Elasticidade } \\
\text { (GPa) }\end{array}$ & 3 & 238 & 358 & 295 \\
\hline $\begin{array}{c}\text { Deformação } \\
\text { na Ruptura } \\
(\%)\end{array}$ & 5 & 1,5 & 0,6 & 1,5 \\
\hline $\begin{array}{l}\text { Densidade } \\
\quad\left(\mathrm{g} \cdot \mathrm{cm}^{-3}\right)\end{array}$ & 1,14 & 1,77 & 1,79 & 1,77 \\
\hline
\end{tabular}

Tabela A1: Principais propriedades da resina epóxi e da fibra de carbono.

Os compósitos poliméricos além de diminuírem o peso da estrutura e elevarem a resistência mecânica e química, também reduzem a cadeia produtiva ao transformar a matéria prima em produto, com a facilidade da liberdade de formas geométricas, impossíveis de serem alcançada por outros materiais. Compósitos não são produtos "de prateleira", não estão prontos para serem utilizados. Primeiro é necessário definir as propriedades desejadas ao produto e depois produzir esse compósito obedecendo às necessidades do projeto.

A função da matriz no compósito é a de auxiliar no posicionamento das fibras e na distribuição de tensões entre os filamentos. Para melhorar a resistência da interface fibra/matriz, a fibra, durante a etapa de fabricação, recebe um tratamento ("finish") e um acabamento superficial ("sizing"). O "finish" tem a finalidade de criar grupos funcionais na superfície das fibras para 
permitir a adesão entre a fibra e a matriz, enquanto que o acabamento superficial consiste da adição de um material orgânico cuja finalidade é proteger o tratamento superficial realizado na fibra, além de facilitar a aglutinação de fios para o "roving" (fiação preliminar). Esse tratamento superficial ajuda no manuseio da fibra durante a fabricação do compósito.

Os compósitos podem ser processados em lâminas com as fibras dispostas em direção pré-estabelecidas de acordo com as direções de carregamento. A sobreposição de várias lâminas gera laminados que podem ser unidirecionais ("on-axis"), com as fibras dispostas sempre na mesma direção, ou multidirecionais se as fibras estiverem dispostas em ângulos diferentes em cada lâmina ("off-axis"). A figura A1 mostra um esquema representativo sobre lâminas e laminados de materiais compósitos.

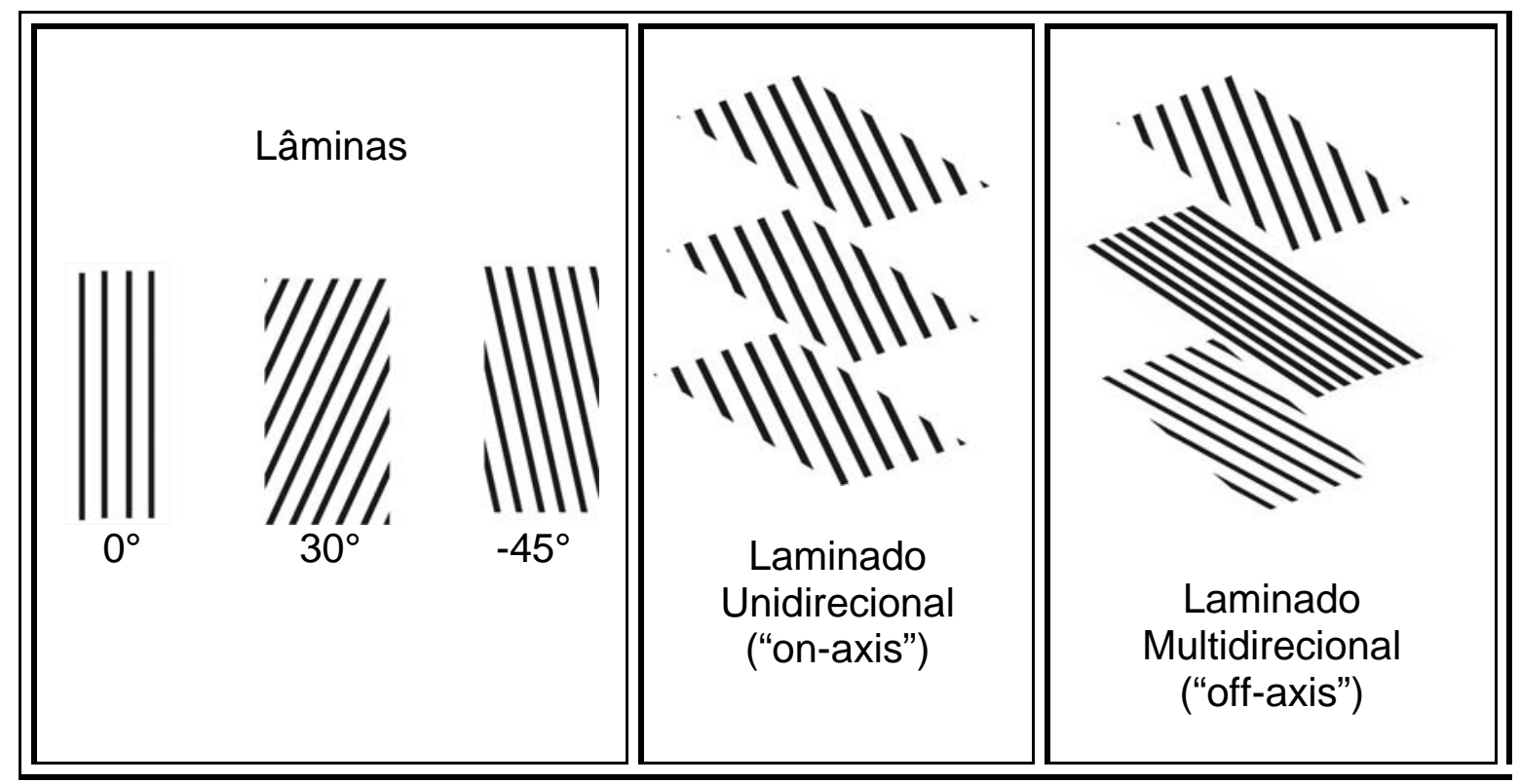

Figura A1: Esquema representativo de materiais compósitos unidirecionais e multidirecionais.

Mecanismos de fratura de compósitos do tipo CFRP

Ao associar dois diferentes materiais com a finalidade de obter um terceiro, devemos levar em conta o fato de que danos podem ocorrer 
diferentemente para cada parte desse material, ou mesmo, ocorrer em apenas um de seus componentes. Embora cada dano separadamente possa, ou não, ser a razão principal da fratura final do material, cada um deles pode contribuir de maneira cumulativa para a falha como um todo.

Uma lâmina de material compósito, reforçado com fibras unidirecionais contínuas, pode apresentar os seguintes danos: trincamento da matriz, fratura da fibra, arrancamento de fibras (pull-out), "ponteamento", descolamento fibra/matriz e trincas na interface. Sob carga compressiva ocorre também a microflambagem, que pode levar a formação de bandas vincadas (kink bands).

Além desses danos, que podem ocorrer independentemente em cada uma das lâminas de um laminado, existem também aqueles que podem afetar o laminado como um todo, como é o caso da microflambagem do laminado, da delaminação, que provoca descolamento entre lâminas e da delaminação por flambagem, um descolamento das lâminas devido à microflambagem.

Na figura A2 é mostrada esquematicamente como cada um desses danos pode ser visualizado no compósito. É interessante notar que é possível encontrar vários tipos de danos em uma só lâmina, mas que um deles pode ser identificado como predominante ou o mais importante para o tipo de estrutura onde o material é utilizado.

Uma descrição resumida sobre cada um destes processos de fratura é apresentada a seguir:

Arrancamento (pull-out) - Durante o carregamento ocorre a quebra da fibra, juntamente com um descolamento fibra/matriz. A morfologia da superfície apresenta pedaços expostos de fibras, cuja distribuição de altura está relacionada com a energia envolvida no processo. 
Ponteamento - Esse tipo de dano aparece quando há apenas um rompimento na matriz, mas a fibra permanece intacta, dando a idéia de uma ponte ligando as partes separadas da matriz.

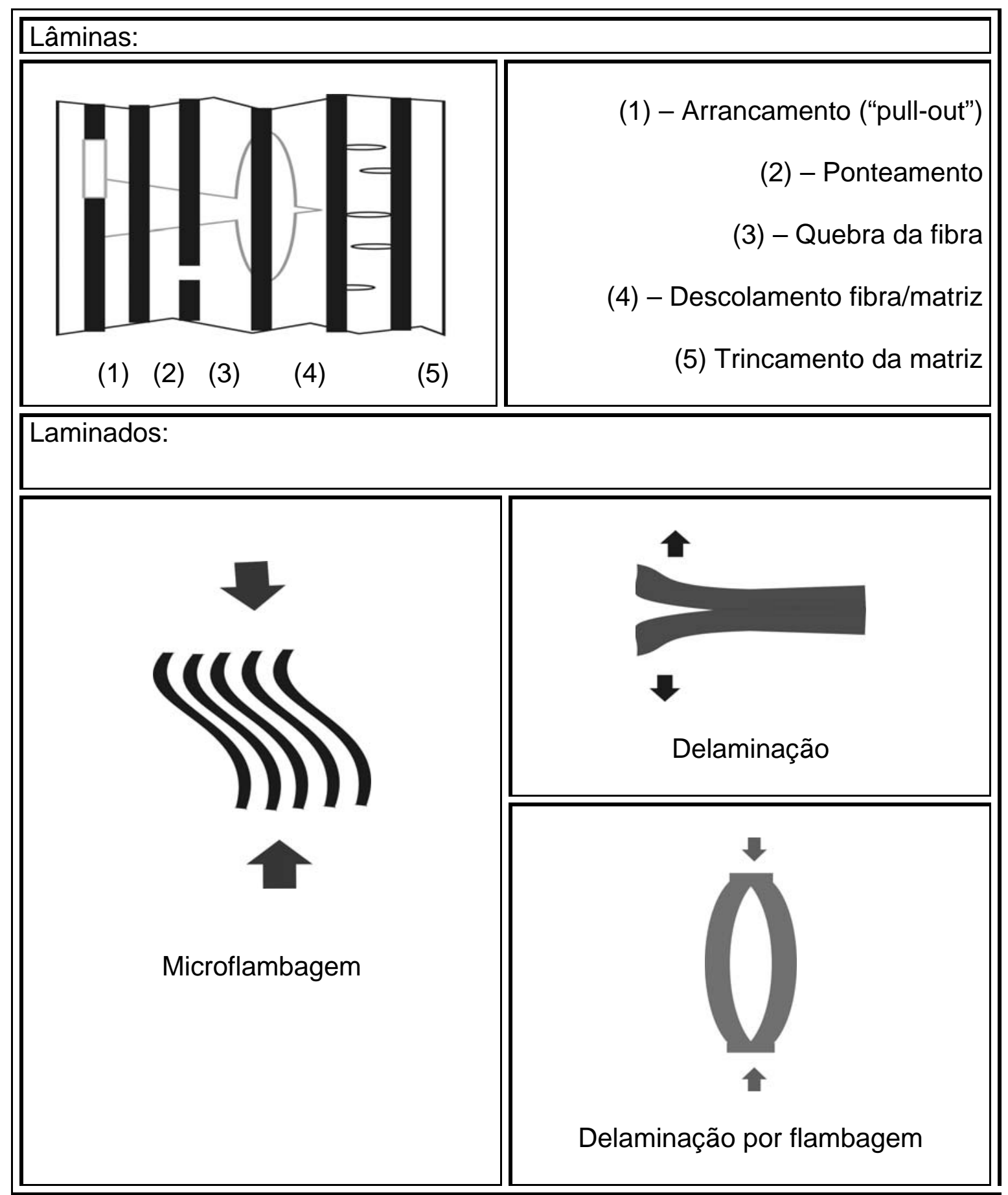

Figura A2: Esquema de danos possíveis de acontecer em lâminas e laminados de materiais compósitos. 
Quebra de fibra - Contrariamente ao ponteamento, a matriz permanece intacta e o rompimento ocorre apenas na fibra, dividindo-a em dois segmentos que permanecem presos à matriz.

Descolamento fibra/matriz - O descolamento é decorrente da fragilidade da interface entre a fibra e a matriz, onde a fibra se descola total ou parcialmente, tornando-se um ponto de fragilidade desse material.

Trincamento da matriz - A não eficácia no processamento da matriz pode produzir pré-trincas ou falhas que, posteriormente, podem vir a gerar uma trinca na matriz. É importante lembrar que, em geral, elas sempre são mais frágeis que o reforço e, portanto, são mais vulneráveis às trincas.

Microflambagem - Sob a ação compressiva, as fibras de reforço tendem a sofrer uma microflambagem, um leve encurvamento. Em alguns casos, essa ação compressiva pode levar a quebra das fibras, com a formação de dois planos de fratura. A região entre esses planos é denominada de bandas vincadas (kink band). Um esquema sobre o processo é mostrado na figura A3.

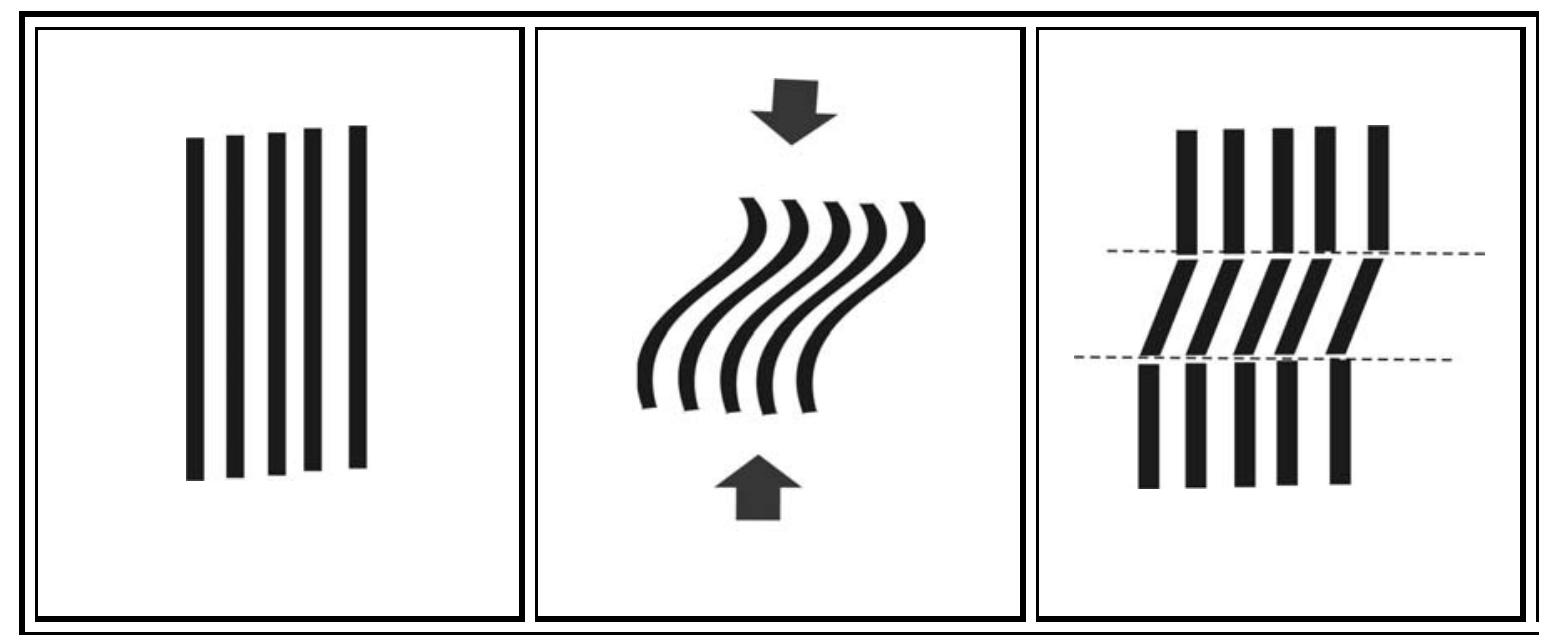

Figura A3: Seqüência de passos que podem levar a formação de bandas vincadas ("kink band"). 
Delaminação - A tensão aplicada em um laminado pode produzir a separação de duas lâminas adjacentes. A região entre essas lâminas geralmente é formada apenas por matriz, o que contribuí com a probabilidade de ocorrência desse fenômeno.

Delaminação por flambagem - Nos laminados, quando a carga compressiva é aplicada na direção das lâminas, pode ocorrer a delaminação por flambagem, ou seja, a flambagem de lâminas adjacentes em regiões onde também ocorre a delaminação.

Na figura 4A é apresentada a imagem de uma superfície de fratura típica de material compósito do tipo CFRP.

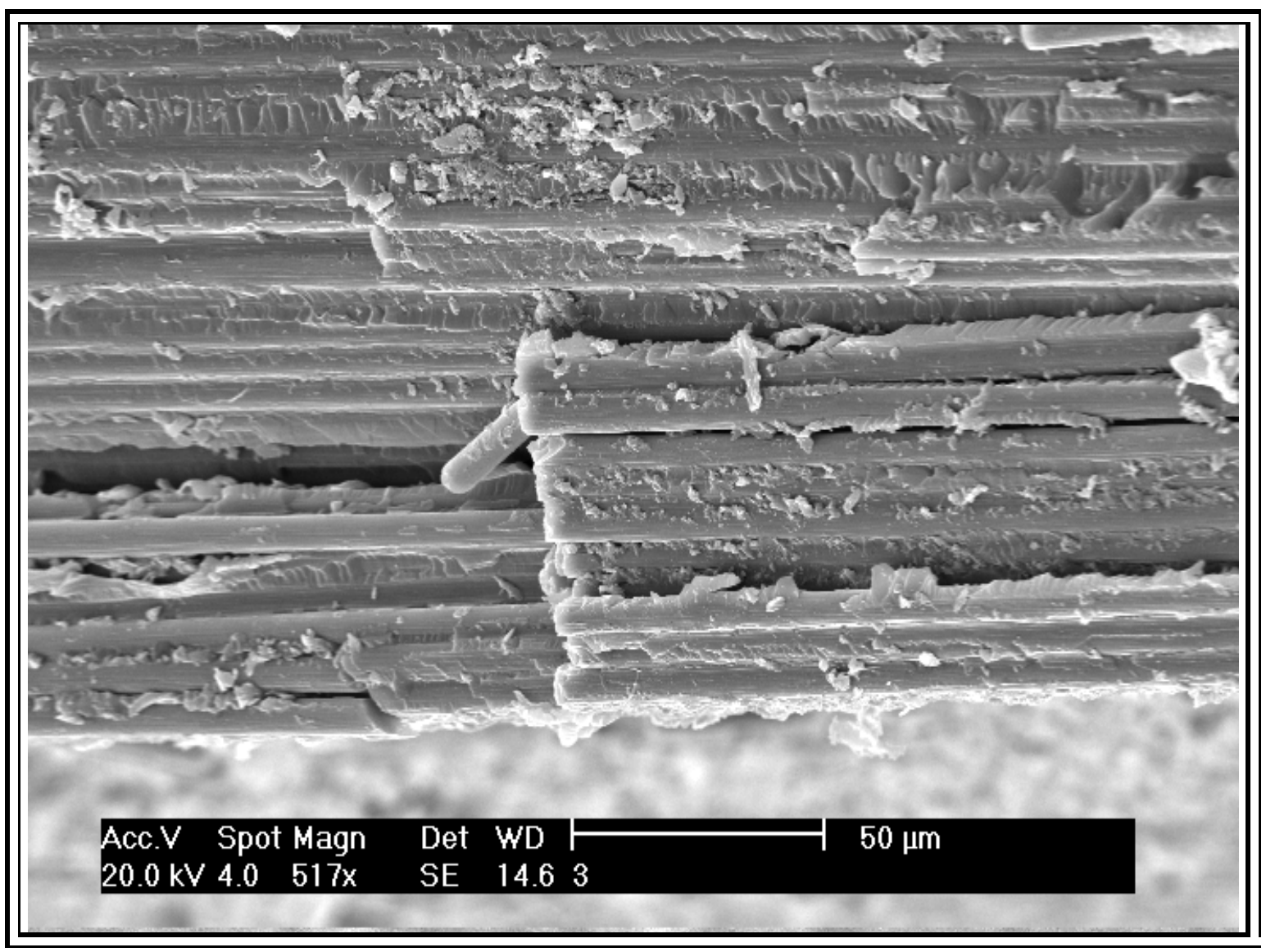

Figura A4: Superfície de fratura de materiais compósitos do tipo CFRP. 


\section{Apêndice B - Formação de imagens em MEV}

O microscópio eletrônico de varredura (MEV) é um equipamento utilizado para observar a estrutura de superfícies de materiais, ou de regiões próxima a ela, através da aplicação de um feixe de elétrons diretamente sobre uma amostra. A figura B1 apresenta um esquema simplificado sobre os principais componentes desse equipamento.

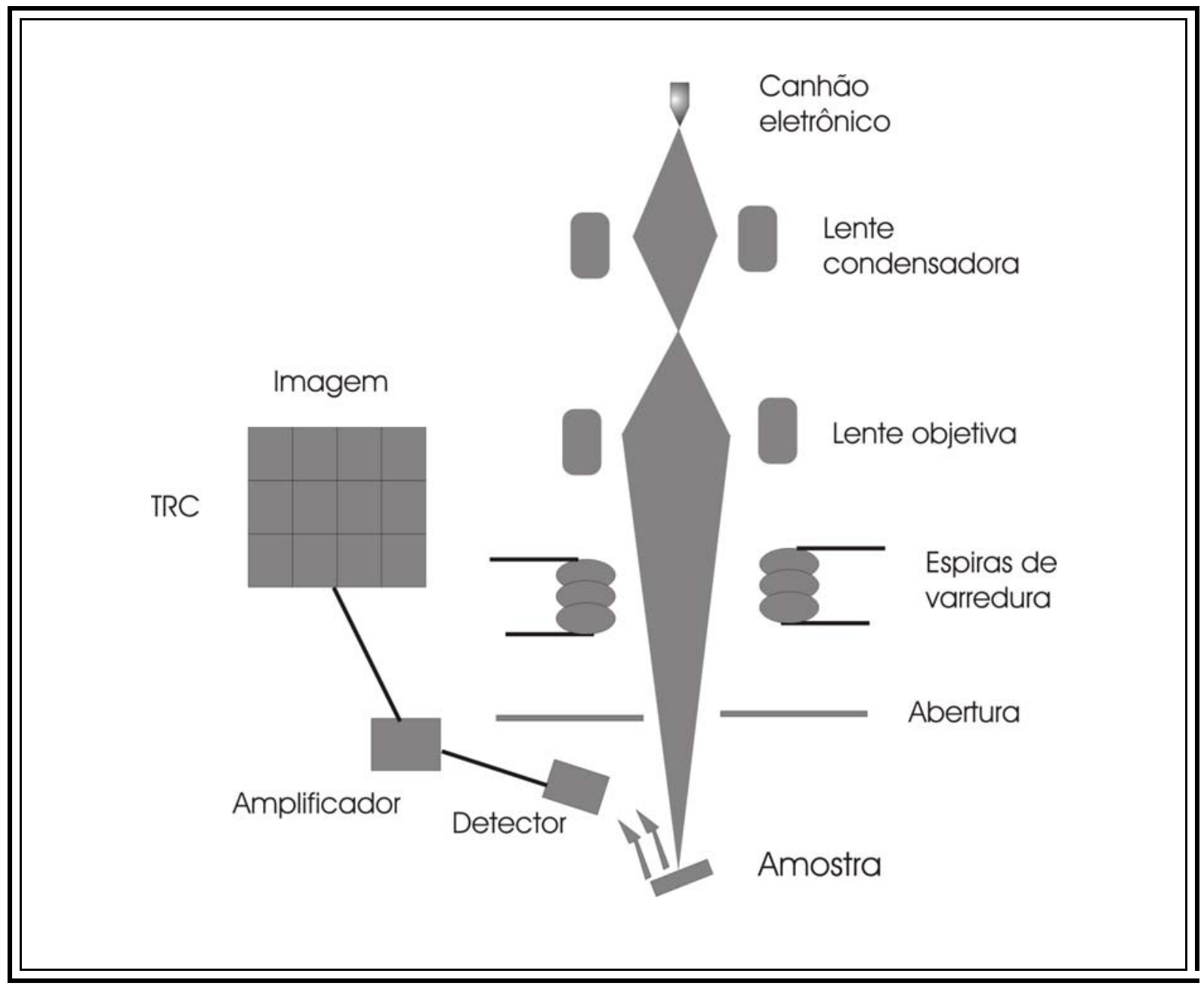

Figura B1: Esquema simplificado dos principais componentes de um MEV. 
O canhão eletrônico é a fonte de elétrons, gerados usualmente por um filamento de tungstênio, por emissão termo-iônica. Os elétrons, que são acelerados até atingirem uma energia entre $1 \mathrm{keV}$ e $30 \mathrm{keV}$, percorrem a coluna do MEV passando por duas ou três lentes condensadoras que diminuem o feixe de elétrons. A lente objetiva tem a função de focalizar o feixe até que este alcance a amostra com um diâmetro que pode variar de 2 à $10 \mathrm{~nm}$. A distância focal da lente objetiva pode ser alterada com a variação de distância entre a amostra e a lente, a chamada distância de trabalho, que ao modificar a convergência do feixe, altera a profundidade de campo e a resolução: quanto maior a distância de trabalho, menor a profundidade de campo e a resolução.

A interação entre o feixe de elétrons primários e a amostra produz vários tipos de sinais, e dependendo da interação específica entre o elétron e a amostra, que pode fornecer diferentes informações sobre ela. A figura B2 apresenta alguns dos sinais que podem ser utilizados em um MEV.

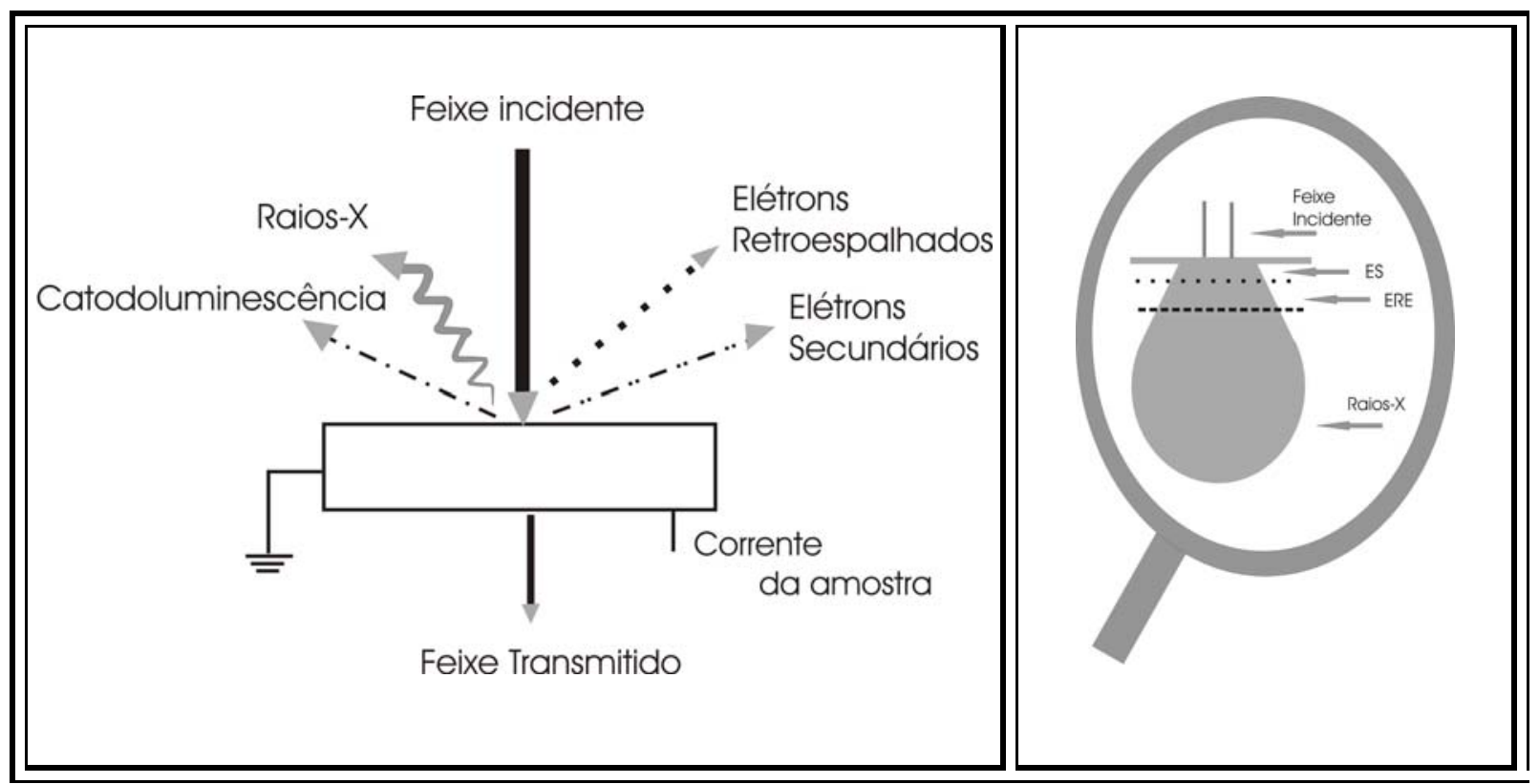

Figura B2: Esquema de interação do feixe incidente com a amostra mostrando sinais produzidos e a região de onde podem ser detectados. 
Cada sinal gerado dentro do volume de interação, ou região onde os elétrons penetram na amostra, requer um detector apropriado que após a aquisição o transforma em sinal elétrico. O detector de elétrons secundários (ES), conhecido como detector Everhart-Thornley, é composto por um cintilador e uma fotomultiplicadora. A luz emitida pelo cintilador, decorrente da interação com os ES, é transmitida a fotomultiplicadora que converte esses fótons em pulsos de elétrons, que serão amplificados e usados para modular a intensidade do tubo de raios catódicos (TRC). Para que os ES, que possuem baixa energia (da ordem de 10 a 50 eV) possam excitar o cintilador, são acelerados por um potencial de $10 \mathrm{kV}$, aplicado ao cintilidor recoberto por uma fina camada de alumínio. Com a finalidade de blindar o feixe primário da influência do potencial do cintilador e permitir que o detector colete todos os ES, mesmo os que não sejam emitidos em sua direção, é colocada uma grade metálica, a um potencial de centenas de volts, em torno do cintilidor.

A imagem formada será do tipo escaneada, ou seja, cada ponto da imagem é apresentado de maneira serial, como as imagens de televisão, onde milhares de pontos são mostrados de forma consecutiva em um processo repetido com alta freqüência que a imagem é visualizada integralmente. Nos equipamentos antigos, o feixe realiza a varredura, através das espiras de varredura, ao mesmo tempo o detector faz a contagem em cada ponto da superfície e, simultaneamente, enquanto o "spot" do TRC varre a tela, seu brilho é modulado pela corrente amplificada do detector. Ambas as varreduras são realizadas de forma similar a um receptor de televisão, que utilizava no princípio um TRC como sistema de transformação de sinais luminosos em elétricos que atualmente foi substituído pelo CCD (Charge Couple Device), que é formado pelo arranjo de grande número de elementos fotossensíveis.

O TRC é um cilindro de vidro, que possuí de um lado uma superfície composta de muitos elementos químicos individuais, sensíveis a luz e disposto 
lado a lado, formando uma linha. Cada elemento, chamado de pixel, é sensibilizado pela projeção da luz refletida por cada objeto, com maior ou menor intensidade. Na direção oposta há um filamento aquecido e um catodo, que emite elétrons quando submetido ao calor do filamento. Entre eles, há uma grade que vai acelerar os elétrons e formar o feixe eletrônico, que podem ser desviados por dois eletroímãs.

A sensibilização dos pixels se dá de forma isolada produzindo um desequilíbrio de cargas, sendo maior quanto mais intensa for a luz. O feixe de elétrons varre cada linha, passando por todos os elementos e equilibrando as quantidades de cargas em cada elemento. O diferencial de cargas de cada pixel é descarregado por um circuito elétrico, gerando diferentes níveis elétricos para cada ponto, de maneira seqüencial, sendo que sinais claros provocam maior desequilíbrio e maior intensidade elétrica. Este processo, chamado de "modelo de varredura", começa no alto da tela e varre todas as linhas ponto a ponto, da esquerda para a direita e de cima para baixo. Uma varredura completa forma um quadro parado da imagem e a quantidade de pontos por linha é chamada de resolução horizontal.

No MEV, o tamanho da varredura realizada pelo feixe eletrônico sobre a amostra é menor que o apresentado no TRC e a ampliação da imagem ocorre de forma linear e representa a razão entre o tamanho da linha no TRC pelo valor do comprimento da linha de varredura da amostra. Para um equipamento analógico, o sinal ampliado do detector é mostrado com alta qualidade no TRC e, o tamanho mínimo de spot que pode ser obtido é da ordem de $100 \mu \mathrm{m}$. No MEV digital, a imagem será registrada em um "framestore", com um número similar de pixels. O spot no TRC (ou framestore de pixels) limita o movimento do feixe de elétrons na amostra, e assim para cada um dos pixels no TRC, existe um pixel correspondente na amostra. 
A resolução de trabalho do equipamento pode ser diferente do tamanho do pixel da amostra, influenciando na resolução final do equipamento. Se o diâmetro de feixe incidente sobre a amostra for maior que o tamanho do pixel da amostra, o sinal do pixel adjacente irá se confundir com ele, degradando a informação. Caso o diâmetro do feixe incidente seja menor que o tamanho do pixel, esse sinal fica mais fraco, parecendo ruído. Portanto, o melhor desempenho será atingido quando o diâmetro do feixe incidente e o tamanho do pixel da amostra forem iguais.

Uma questão importante para a qualidade das imagens que são adquiridas no MEV, principalmente no caso de pares estéreos, que registram a mesma região de interesse tomada em ângulos de inclinação diferentes, é o posicionamento eucêntrico dessas regiões. Nessa posição, a região se mantém centralizada com relação ao feixe, mesmo após uma inclinação ou rotação em qualquer direção, o estágio inclinado e o eixo do feixe se interceptam.

Os esquemas apresentados na figura B3 mostram as diferenças entre os posicionamentos não eucêntricos e eucêntricos de uma região de interesse da amostra. Para encontrar o posicionamento eucêntrico de qualquer região da amostra, deve-se realizar uma série de procedimentos, apresentada a seguir para um MEV Philips, modelo XL-30:

$\left.1^{\circ}\right)$ Dentro do menu "Stage", aplicar a função "Auto Beam Shift Zero";

$2^{\circ}$ ) No menu "Window", aplicar "Center Cross", ou pelo teclado (shift + F5).

Uma cruz vermelha será marcada no centro da tela;

$3^{\circ}$ ) Focalize a imagem. Selecione "Link $Z$ to FWD" e vá para uma "WD" (distância de trabalho) de $10 \mathrm{~mm}$;

$4^{\circ}$ ) Coloque em $0^{\circ}$ a inclinação do estágio;

$5^{\circ}$ ) Usando o controle " $Z$ ", encontre um foco grosseiro da imagem;

$6^{\circ}$ ) Fixe uma ampliação de 1000x, encontre uma característica reconhecível e a centralize sob a cruz vermelha, movendo o estágio; 
$7^{\circ}$ ) Observe essa característica e altere o ângulo de inclinação do estágio para $15^{\circ}$. Usando apenas o controle "Z" e, traga a característica novamente para o centro da tela, sob a cruz;

$8^{\circ}$ ) Altere novamente a inclinação do estágio para $30^{\circ} \mathrm{e}$, posicione a característica novamente sob a cruz, utilizando apenas o controle " $Z$ ";

$9^{\circ}$ ) Volte para a posição $0^{\circ}$ de inclinação. A característica não deve ter um afastamento maior que $5 \mu \mathrm{m}$. Se isso ocorrer, repetir os passos de 6 à 9 .

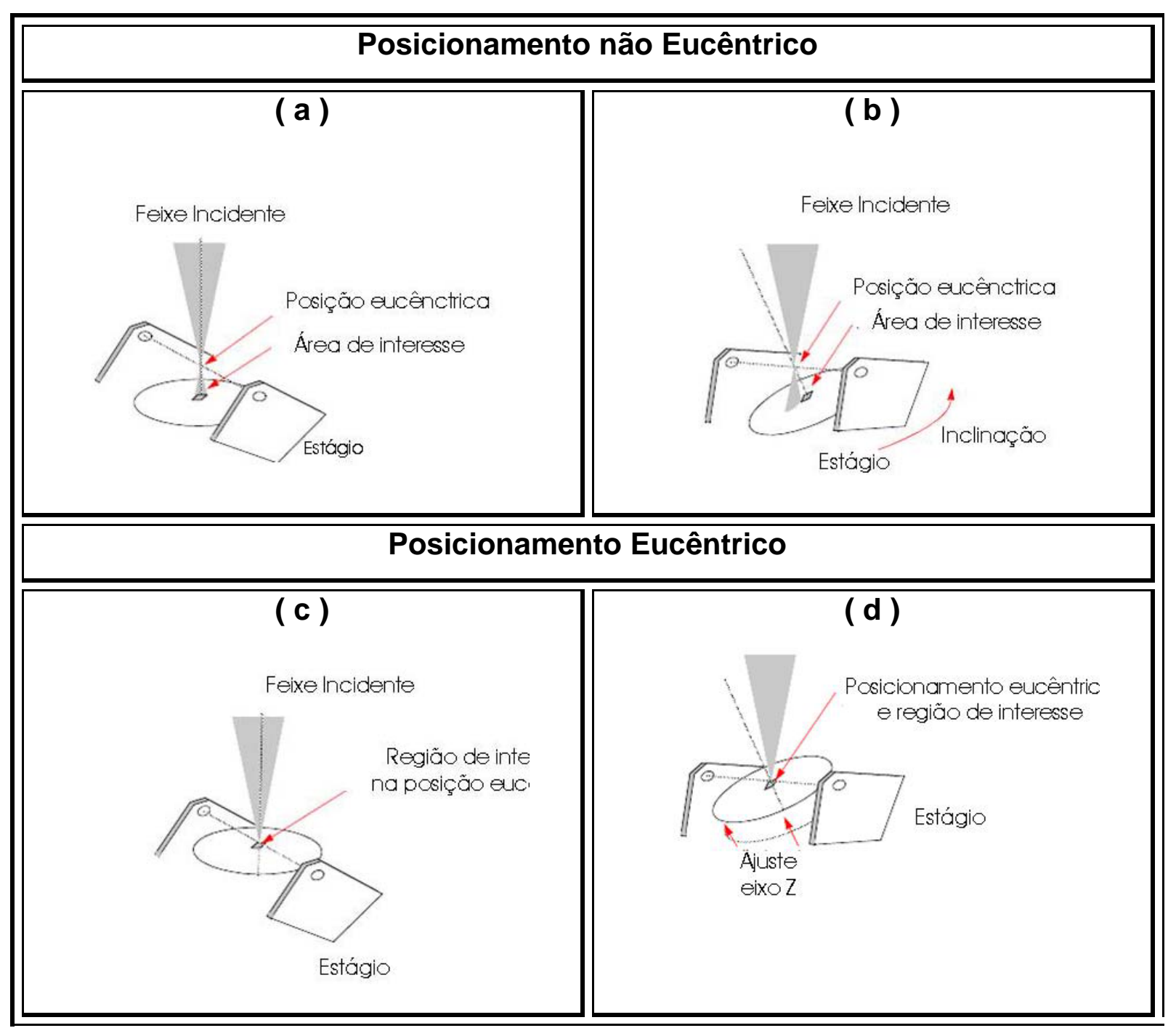

Figura B3: Esquemas mostrando a diferença entre o posicionamento não eucêntrico em (a) e (b) e o posicionamento eucêntrico em (c) e (d), (Philips). 


\section{Referências}

1 - Tomita, Y.; Tempaku, M. Effect of fiber strength on tensile fracture of unidirectional long carbon fiber-reinforced epoxy matrix composites. Materials Characterization, v. 38, p. 91-96, 1997.

2 - Morioka, K.; Tomita, Y. Effect of lay-up sequences on mechanical properties and fracture behavior of CFRP laminate composites. Materials Characterization, v. 45, p.125-136, 2000.

3 - Tewari, A.; Gokhale, A. M. Nearest neighbor distances in uniaxial fiber composites. Computacional Materials Science, v. 31, p.13-23, 2004.

4 - Smmazçelik, T.; Arici, A. A.; Günay, V. Impact-fatigue behaviour of unidireccional carbon fibre reinforced polyetherimide $(\mathrm{PEI})$ composites. Journal of Materials Science, v. 41, p.6237-6244, 2006.

5 - Ratna, D. Toughened FRP composites reinforced with glass and carbon fiber. Composites A, v. 39, p. 462-469, 2007.

6 - Sudamarisman, I. J. D. The effect of processing parameters on the flexural properties of unidirectional carbon fibre-reinforced polymer (CFRP) composites. Materials Science and Engineering A, v. 498, p. 65-68, 2008.

7 - Requena, G.; Fiedler, G.; Seiser, B.; Degischer, P.; Michiel, M. D.; Buslaps, T. 3D-Quantification of the distribution of continuous fibres in unidirectionally reinforced composites. Composites: Part A, v. 40, p. 152163, 2009. 
8 - Johannesson, T.; Sjöblom, P.; Seldén, R. The detailed structure of delamination fracture surfaces in graphite/epoxy laminates. Journal of Materials Science, v. 19, p. 1171 - 1177, 1984.

9 - Morioka, K.; Tomita, Y.; Takigawa, K. High-temperature fracture properties of CFRP composite for aerospace application. Materials Science and Engineering, v. A, p. 675-678, 2001.

10 - Beaumont, P. W. R. Targeting problems of composite failure (Editorial). Journal of Material Science, v. 43, p. 6575-6577, 2008.

11- Purslow, D. Some fundamental aspects of composites fractography. Composites, p. $241-247,1981$.

12 - Purslow, D. Composites fractography without an SEM - the failure analysis of a CFRP I-beam. Composites, vol 15, pg 43-48, 1984.

13 - Purslow, D. Matrix fractography of fibre-reinforced epoxy composites. Composites, vol 17, pg $289-303,1986$.

14 - Shikhmanter, L.; Eldror, I.; Cina, B. Fractography of unidirectional CFRP composites. Journal of Materials Science, vol 24, pg 167 - 172, 1989.

15 - Shikhmanter, L.; Cina, B.; Eldror, I. Fractography of multidirectional CFRP composites tested statically. Composites, vol 22, pg 437 - 444, 1991.

16 - Lienkamp, M.; Exner, H. E. Assessment of overload profiles and interfacial shear strength in unidirectional fibre composites via quantitative fractography. Materials Science and Technology, v. 10, p. 526-530, 1994. 
17 - Brooks, C. R.; McGill, B. L. The application of scanning electron microscopy to fractography. Materials Characterization, v. 33, p. 195-243, 1994.

18 - Hilders, O. A.; Pilo, D. On the developmente of a relation between fractal dimension and impact toughness. Materials Characterization, v. 38, p. $121-127,1997$.

19 - Li, X. W.; Tian, J. F.; Li, S. X.; Wang, Z. G. Application of a fractal method to quantitatively discribe some typical fracture surfaces. Materials Transactions, v. 42, p.128-131, 2001.

20 - Horovistiz, A. L.; Ribeiro, L. M. F.; Campos, K. A.; Jesuíno, G. A.; Guimarães, V. A.; Hein, L. R. O. Quantitative fractography under light microscopy: A digital image processing approach. Practical Metallography, v. 40, p. 57-68, 2003.

21 - Ammann, J. J.; Hein, L. R.; Nazar, A. M. Three-dimensional reconstruction of fracture surfaces. Materials Characterization, v. 36, p.379-386, 1996.

22 - Kral, M. V.; Mangan, M. A.; Spanos, G.; Rosenberg, R. O. Threedimensional analysis of microstructures. Materials Characterization, v. 45, p. 17-23, 2000.

23 - Cheng,Y.; Hartemink, C. A.; Hartwig, J. H.; Dewey Jr.,C. F. Threedimensional reconstruction of the actin cytoskeleton from stereo images. Journal of Biomechanics, v. 33, p. 105-113, 2000.

24 - Hein, L. R. O. Quantitative fractography by digital image processing: $\mathrm{NIH}$ image macro tools for stereo pair analysis and 3-D reconstruction. Journal of Microscopy, v.204, p. 17-28, 2001. 
25 - Pouchou, J.; Boivin, D.; Beauchêne, P.; Le Besnerais, G.; Vignon, F. 3D reconstruction of rough surfaces by SEM stereo imaging. Mikrochimica Acta, v. 139, p. 135-144, 2002.

26- Kuroda, T.; Ikeuchi, K.; Nakade, K.; Inoue, K.; Kitagawa, Y. Threedimensional reconstruction of cleavage fracture surface for duplex stailess steel. Vacuum, v. 65, p. 541-546, 2002.

27 - Marinucci, G. Desenvolvimento, fabricação e análise de fratura de cilindros de fibras de carbono colapsados por pressão interna. Tese de Doutorado, Instituto de Pesquisas Energéticas e Nucleares, 2001.

28 - Lucena, E. F. Estudo de algoritmos para reconstrução de relevos de superfícies irregulares: aplicação na fractografia quantitativa e caracterização de materiais. Tese de Doutorado, Universidade Estadual Paulista - Campus de Guaratinguetá, Fevereiro, 2004. 